2. To: (Recelving Organization)

Plutonium Finishing Plant (PFP)

5. Proj./Prog./Dept./Div.:

Annual Upadate of PFP FSAR

8. Originator Remarks:

The PFP FSAR was initially prepared to the format and content guidance to Nuclear Regulatory Guide 3.39. This compares and evaluates the current FSAR with the guidance of DOE-STD-3009-94. The comparison table provides areas of compliance and descrepancies.

11. Receiver Remarks:

11A. Deeign Bacaline Document? $\square$ Yes $\square$ No

None

\section{From: (Originating Organization) \\ Fluor Federal services}

6. Design Authority/Dedign AgentCog. Engr::

A. I. Ramble/M. K. Ullah

\section{Related EDT No.: \\ 627571 \\ 7. Purchase Order No.: \\ 9. Equip./Component No.: \\ $\mathrm{N} / \mathrm{A}$ \\ 10. Syatem/Bldg./Facility: \\ $\mathrm{N} / \mathrm{A}$}

12. Major Asam. Dwo. No.:

N/A

13. Permiterermil Application No:

$\mathrm{N} / \mathrm{A}$

14. Required Response Date:

\begin{tabular}{|l|l|}
\hline 15. \\
\hline $\begin{array}{l}\text { (A) } \\
\text { Item } \\
\text { No. }\end{array}$ & (B) Document/Drawing No. \\
\hline 1 & HNF-6533 \\
\hline & \\
\hline & \\
\hline & \\
\hline & \\
\hline & \\
\hline & \\
\hline
\end{tabular}

16. DATA TRANSMITTED

\begin{tabular}{l|l|l} 
(C) Sheet & (D) Rov. & (E) Title or Description of Data Tranamitted \\
No. & (E)
\end{tabular} (F)

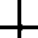

Comparison Evaluation of
the PFP FSAR (HNF-SD-CP-
SAR-021) and NRC

\begin{tabular}{|l|}
\hline 0 \\
\hline \\
\hline
\end{tabular}

Regulatory Guide 3.39 with DOE-STD-3009-94.

\begin{tabular}{|c|l|}
\hline Approval Designator (F) & \\
\hline $\begin{array}{c}\text { ES, O D OR N/A } \\
\text { (See WHC.CM-3-5, } \\
\text { Sec. 12.7) }\end{array}$ & $\begin{array}{l}\text { 1. Approval } \\
\text { 2. Release } \\
\text { 3. Information }\end{array}$ \\
\hline
\end{tabular}

17.

Reason for Tranemittal (G)

KEY
Dlsposition (H) \& (I)

$\begin{array}{ll}\text { 1. Approved } & \text { 4. Revlewed no/comment } \\ \text { 2. Approved w/comment } & \text { 5. Reviewed w/comment } \\ \text { 3. Dleapproved w/comment } & \text { 6. Recolpt acknowledged }\end{array}$

4. Review

5. Post-Review SIGNATURE/DISTRIBUTION

(See Approval Designator for required elgnatures)

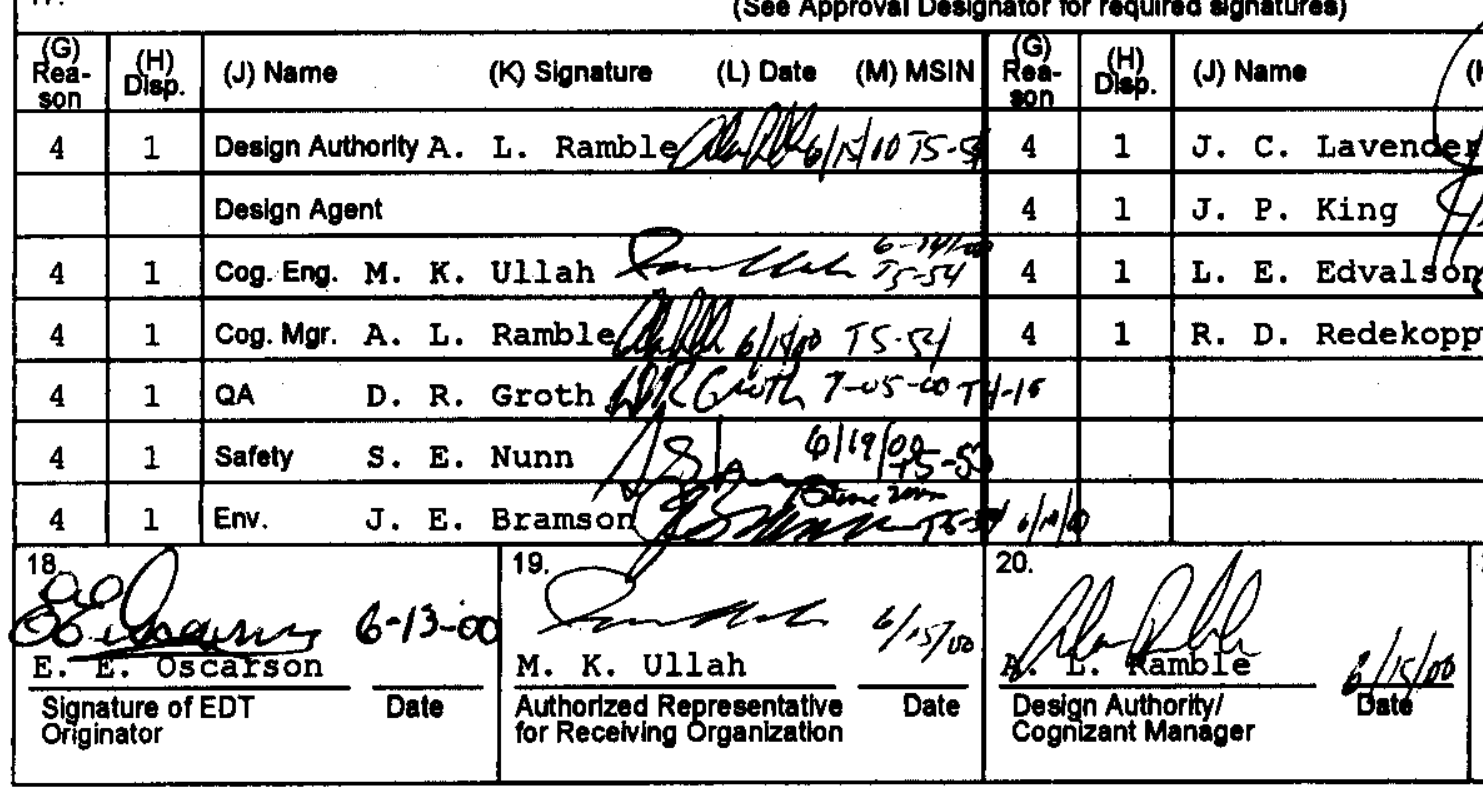

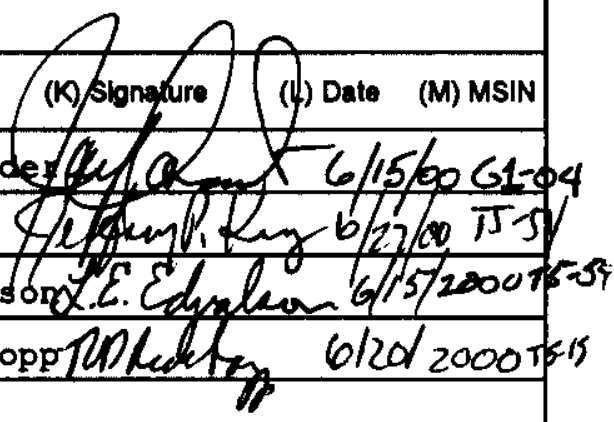


HNF-6533

Revision 0

\section{Comparison Evaluation of the PFP FSAR and NRC Regulatory Guide 3.39 with DOE-STD-3009-94}

Prepared for the U.S. Department of Energy

Assistant Secretary for Environmental Management

Project Hanford Management Contractor for the

U.S. Department of Energy under Contract DE-ACD6-S6RL13200

Fluor Hanford

P.O. Box 1000

Richland, Washington 
HNF-6533

Revision 0

\title{
Comparison Evaluation of the PFP FSAR and NRC Regulatory Guide 3.39 with DOE-STD-3009-94
}

\author{
E. E. Oscarson
}

Fluor Federal Services

Date Published

June 2000

Prepared for the U.S. Department of Energy

Assistant Secretary for Environmental Management

Project Hanford Management Contractor for the

U.S. Department of Energy under Contract DE-ACO6-96RL13200

Fluor Hanford

P.0. Box 1000

Richiand, Washington
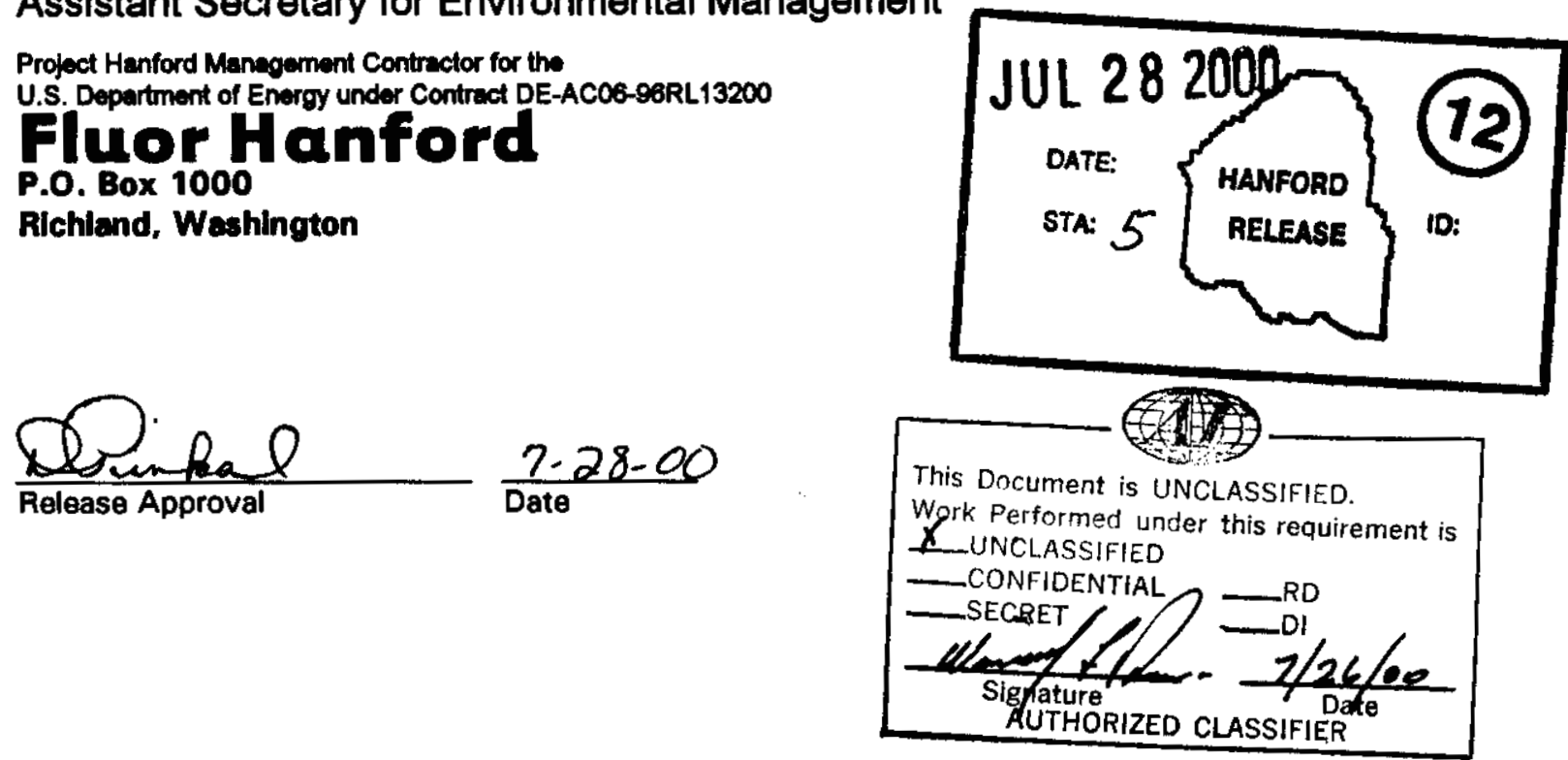
TRADEMARK DISCLAMER

Reference hereln to any speclific commercial product, process,

or service by trade name, trademark, manufacturer, or

otherwiee, does not neceesarilly constitute or imply its

endoreement, recommendation, or favoring by the United

States Govemment or any agency thereof or its contractors or

subcontractors.

This report has been reproduced from the best avallable copy.

Printed in the United Stutes of Amerten

Total Pages 112 
HNF-6533

Rev. 0

\section{Comparison Evaluation of the PFP FSAR (HNF-SD-CP-SAR-021) and NRC Regulatory Guide 3.39 with DOE-STD-3009-94}

Prepared by: E. E. Oscarson

Fluor Federal Services

For:

Fluor Hanford, Inc.

Date Published

June 2000

Approved by:
Fluor Hanford, Inc.

Prepared for the U. S. Department of Energy

Fluor Hanford, Inc.

Richland, Washington

Hanford Management and Integration Contractor for the

U.S. Department of Energy under Contract DE-AC06-96RL13200 
HNF-6533 Rev. 0

This page intentionally left blank. 
HNF-6533 Rev. 0

\section{PREFACE}

This comparison evaluation of the Plutonium Finishing Plant (PFP) Final Safety Analysis Report (FSAR) with the format and content guidance of U.S. Nuclear Regulatory Commission (NRC) Regulatory Guide 3.39 and DOE-STD-3009-94, was prepared by Fluor Federal Services (FFS) for the Plutonium Finishing Plant. The following analysts participated in the development and review of this document: Eric E. Oscarson; Jay C. Lavender; James E. Shapley; and M. Kaleem Ullah. 
HNF-6533 Rev. 0

\section{TABLE OF CONTENTS}

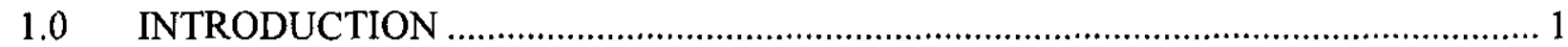

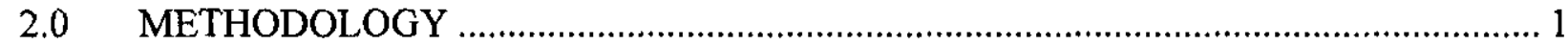

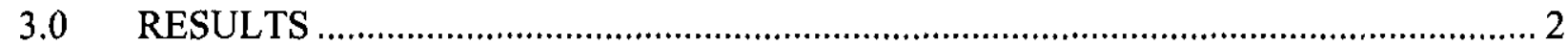

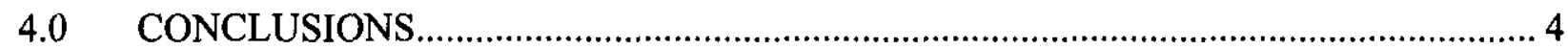

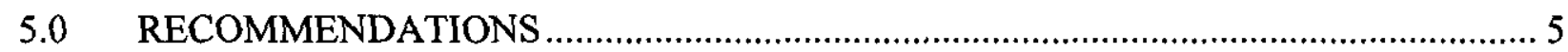

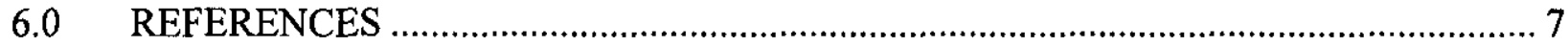

APPENDIX A - COMPARISON BETWEEN SAFETY ANALYSIS FORMAT REQUIREMENTS CONTAINED IN DOE-STD-3009-94 AND NRC REGULATORY GUIDE 3.39 .

\section{LIST OF TABLES}

Table 1. Evaluation of PFP FSAR and NRC Regulatory Guide 3.39 Compliance with the Safety Analysis Format and Content Requirements in DOE-STD-3009-94 9 


\section{Comparison Evaluation of the PFP FSAR and NRC Regulatory Guide 3.39 with DOE-STD-3009-94}

\subsection{INTRODUCTION}

One of the Plutonium Finishing Plant's (PFP) current Authorization Basis (AB) documents is the Final Safety Analysis Report (FSAR). This FSAR (HNF-SD-CP-SAR-021) was prepared to the format and content guidance specified in U.S. Nuclear Regulatory Commission (NRC) Regulatory Guide 3.39, Standard Format and Content of License Applications for Plutonium Processing and Fuel Fabrication Plants (RG 3.39). In April 1992, the U.S. Department of Energy (DOE) issued DOE Order 5480.23 which established the FSAR requirements for DOE nonreactor nuclear facilities. In 1994, DOE issued DOE-STD-3009-94, Preparation Guide for U.S. Department of Energy Nonreactor Nuclear Facility Safety Analysis Reports, which is a format and content guide addressing the preparation of FSARs in accordance with DOE Order 5480.23 .

During the initial preparation and issuance of the PFP FSAR the format and content guidance contained in NRC Regulatory Guide 3.39 was utilized, since it was the most applicable guidance at the time for the preparation of Safety Analysis Reports for plutonium processing plants. With the adoption of DOE Order 5480.23 and DOE-STD-3009-94, DOE required the preparation of SARs to meet the format and content of those DOE documents. The PFP was granted an exemption to continue with RG 3.39 format for future FSAR revisions. PFP modifications and additions have required PFP FSAR modifications that have typically been prepared to the same NRC Regulatory Guide 3.39 format and content, to provide consistency with the PFP FSAR.

This document provides a table comparison between the 3009 and RG 3.39 formats to validate the extent of PFP FSAR compliance with the intent of DOE Order 5480.23 and DOESTD-3009-94. This evaluation was initially performed on Revisions 1 and 1A of the PFP FSAR. With the preparation of a Revision 2 draft to the FSAR, sections with significant changes were reevaluated for compliance and the tables were updated, as appropriate. The tables resulting from this comparison provide a "road map" between the RG 3.39 format of the PFP FSAR and the requirements of 3009 , to verify compliance with 3009 and identify any discrepancies. Because of the format differences between the RG 3.39 and 3009 guidance, the extent to which the PFP FSAR complies with 3009 is not entirely clear. No comparative evaluation of the existing PFP OSRs to the requirements contained in Chapter 5 of 3009 was performed.

\subsection{METHODOLOGY}

This comparison evaluation between the safety analysis requirements in DOE-STD-3009-94, those in NRC Regulatory Guide 3.39, and the implementation of RG 3.39 guidance in the PFP FSAR began with a tabular listing of the 3009 requirements. Next a team of 
Safety Analysts, utilizing good engineering judgement and knowledge of both the NRC and DOE SAR guidance documents, reviewed the Regulatory Guide 3.39 guidance against each of the 3009 requirements, or topics, and correlate the various sections of RG 3.39 with the corresponding 3009 requirement section. The correlation of the requirements of RG 3.39 to 3009 is presented in Appendix A. Since the PFP FSAR was prepared to the requirements of RG 3.39 , the evaluation of the level of compliance of the FSAR with the intent of 3009 guidance is based upon the comparison between the requirements of RG 3.39 and 3009 contained in Appendix A. The evaluation team considered the change in facility mission from plutonium material processing to material stabilization and facility transition to decontamination and decommissioning (D\&D). The team focused on current operations and those 3009 requirements necessary to ensure safe facility operations. The results of the comparative evaluation of the FSAR with the two guidance documents are tabulated in Table 1.

The compliance evaluation in Table 1 was developed by assigning one of three categories of compliance (i.e., Meets intent of 3009; Partially meets 3009; or Does not meet 3009) to those RG 3.39 and related PFP FSAR sections, which correspond to each section or subsection of 3009 .

"Meets intent of 3009 " refers to those RG 3.39 or PFP FSAR sections that adequately describe or summarize the required material within a 3009 section. The evaluation that the referenced sections meet the intent of 3009 guidance is based upon a direct comparison of each section against the specific 3009 section. The RG 3.39 or PFP FSAR chapters/sections applicable to each evaluation are contained in the appropriate columns of Table 1.

"Partially meets 3009" refers to those RG 3.39 or PFP FSAR sections that do not fully meet the intent of 3009 guidance, either through omissions of information or lack of adequate detail in the presentation. Where more than one subtopic is covered in a 3009 section, lack of coverage of all the subtopics may be considered as partially meeting the requirements. If too much information is lacking the level of compliance may be considered as "Does not meet 3009."

"Does not meet 3009" refers to those sections (topics) of 3009 which are either not addressed at all, or that were not adequately addressed within RG 3.39 or the PFP FSAR. Certain major topics or chapters of 3009 have very few or no sections that are not at least partially met by RG 3.39 or the PFP FSAR, while other chapters are essentially missing from the FSAR.

The results of this comparative evaluation are summarized in the following section.

\subsection{RESULTS}

This section presents the results of the comparative evaluation of the PFP FSAR (which was prepared to the requirements of RG 3.39) with the format and content guidance contained in DOE-STD-3009-94, Preparation Guide for U.S. Department of Energy Nonreactor Nuclear Facility Safety Analysis Reports. This comparative evaluation applies to the main body of the 
PFP FSAR, and not necessarily to the various addenda and appendices. The more recent addenda, and those in preparation, have been structured and formatted to comply with chapters 2 , 3,4 , and 5 of the 3009 guidance document. No comparative evaluation of the existing PFP OSRs to the requirements contained in Chapter 5 of 3009 was performed.

Table 1 is a detailed listing of the approximately two hundred (200) DOE-STD-3009-94 topics (sections or subsections), the corresponding RG 3.39 and PFP FSAR sections, and the level of compliance with 3009 along with the rationale, where appropriate. A summary description of each level of compliance follows.

1. Meets intent of 3009 .

Of the approximately 200 topics or sections addressed in 3009 , there were 92 that were evaluated as being fully met by the PFP FSAR. The referenced sections were considered to at least meet the minimum requirements of 3009 , and in many cases contained more information than was required. For example, most of the sections that address the chapter on "Site Characteristics" contain more detail and description than is required by either RG 3.39 or 3009 . However, some sections may be considered to marginally meet the 3009 requirements. This category includes several sections relating to "Hazard Analysis" which utilize data and analysis in the appendices to supplement the chapter text.

There were Introduction and Requirements sections for each of the 17 chapters in 3009 . Due to adherence to the format and content structure of RG 3.39, the PFP FSAR has no directly comparable sections. However, because each chapter and major subsection in the PFP FSAR contains introductory material in each of its chapters and major discussions or subsections, and has requirements embedded in the text, it was determined that the PFP FSAR meets the intent of 3009 for these sections. Although the material is structured in a different format, and the relevant references to requirements documents are contained within the body of the document text, the intent of 31 more sections of 3009 are considered to be met.

\section{Partially meets 3009 .}

There were 48 topics in which the PFP FSAR was evaluated as only partially meeting the intent of 3009 guidance. Lack of adequate detail in some sections occurs when the required information is contained in supporting documents and only referenced in the FSAR without summarizing the information contained in the supporting document. As required in the 3009 SAR guidance, these chapters/sections need to contain summaries of the referenced information to be considered as fully meeting the intent of 3009. An example of this type of partial compliance would be the chapters on the "Derivation of Technical Safety Requirements" and "Quality Assurance," and the section on "Conduct of Operations." In those cases the reader is directed to PFP administrative procedures and supporting documents for both the summary and details of the programs. These procedures and supporting documents were not reviewed for compliance. 


\section{Does not meet 3009 .}

Out of the approximately 200 topics evaluated for compliance with 3009 , there were 22 that were considered not to meet the requirements in 3009 . Approximately one half of missing or inadequate information relates to the following two chapters: Chapter 8 - Hazardous Material Protection and Chapter 13 - Human Factors. These two chapters accounted for 10 of the 22 "Does not meet 3009" items. Hazardous material protection is addressed in several administrative procedures and supporting documents which are not summarized and/or referenced in the PFP FSAR. These documents contain adequate information to satisfy the requirements of 3009 , however, 3009 requires a reasonable description or summary of the programs (topics) within the FSAR itself, and adequate references to the external documents. Therefore, the preparation of more complete summary sections for the Hazardous Material Protection program would move most of the inadequate sections into the category of "Meets or partially meets the intent of 3009." Chapter 13 - Human Factors has not been addressed at all within RG 3.39 or the PFP FSAR.

\subsection{CONCLUSIONS}

Of the approximately 200 topics or sections addressed in 3009 , there were 92 that were evaluated as being fully met in the PFP FSAR. The compliant sections were considered to at least meet the minimum requirements of 3009 , and in some cases contained more information than was required. In addition, there are 31 Introduction and Reference sections that are considered to meet the intent of 3009 .

There were 48 topics in which the PFP FSAR was evaluated as only partially meeting the intent of 3009 guidance. The following 3009 chapters/sections contain the majority of requirements that are only partially met in the PFP FSAR:

- Chapter 5 - Derivation of Technical Safety Requirements,

- Chapter 8 - Hazardous Material Protection,

- Chapter 14 - Quality Assurance,

- Section 11.3 - Conduct of Operations.

There were 22 sections of the 3009 guidance document which were not adequately addressed in the PFP FSAR. Approximately one half of missing or inadequate information relates to the following 3009 chapters:

- Chapter 8- Hazardous Material Protection,

- Chapter 13 - Human Factors.

The addition of a new section, "10.4.5 Chemical Management Programs," to Revision 2 of the PFP FSAR addresses about half of the Hazardous Material Protection sections or subsections ( 8 out of 13) in Chapter 8 of 3009 which had previously been considered not to be met. The degree of compliance addressed in those sections of 10.4 .5 vary from "Partially meets" to "Meets the intent of 3009 ." 
The comparative evaluation results and conclusions may change somewhat based upon results of the review of Revision 2 and the final incorporation of comments. It is anticipated that the changes resulting from comment incorporation will be small.

\subsection{RECOMMENDATIONS}

There are several areas where additions or modifications to the PFP FSAR text would result in closer compliance with the intent of DOE-STD-3009-94 guidance. These are identified as recommendations. Following is a listing of these recommendations, ranked according to the estimated order of importance:

1. The topic of hazardous material protection is not adequately addressed in the PFP FSAR. In Revision 1 of the FSAR there are only fragments of the hazardous material protection program, and they are scattered throughout various chapters and sections. There is a need to summarize in one place those aspects of the PFP hazardous material protection program, which are currently contained in administrative procedures. The draft of Revision 2 moves 8 of 13 sections from the "Does not meet 3009 " category to the "Meets intent of 3009" (2) or "Partially meets 3009" (6) (see 4.0 Conclusions, regarding Revision 2).

2. Chapter 10.0, "Conduct of Operations," of the PFP FSAR is not structured to address the topics listed in Section 11.3 of 3009. Those listed topics are identified in Section 10.8, "Compliance with DOE Order 5480.19." However, there are no topic summaries, but only references to PFP administrative procedures and to DOE Order 5480.19. It is recommended that this FSAR section be revised to summarize the PFP Conduct of Operations program.

3. The PFP FSAR does not address the topic of Quality Assurance (Chapter 12.0) in sufficient detail to fully meet the intent of 3009 guidance. This chapter needs to be expanded to summarize those aspects of the QA program contained in FSP-PFP-5-8, Section 15.1, relating to: requirements; organization; quality improvement; documents and records; and QA performance, as specified in Chapter 14 of 3009.

4. Another potential area for improvements in the PFP FSAR relates to the organization and content of the Hazard and Accident Analysis chapter/sections. There exist numerous inconsistencies in format and content between recent and older analyzed accidents; and between FSAR Chapter 9 and the Chapter 9 appendices and addenda. This revision should include sections addressing or providing additional clarification regarding the selection of engineered and administrative barriers for accident mitigation, and to provide consistent bases for derivation of OSRs (TSRs).

PFP FSAR Chapter 11.0, "Operational Safety Requirements" (OSRs) was prepared to point the reader to the OSR document, WHC-SD-CP-OSR-010. This FSAR chapter currently does not address the "Derivation of Technical Safety Requirements" (DOE- 
STD-3009, Chapter 5), provide their bases, or summarize the OSR program. This chapter should be expanded to support and provide the information necessary for the separate TSR (OSR) document, and should consist of summaries and references to pertinent sections of the FSAR in which design and administrative features are needed to prevent or mitigate the consequences of accidents. This chapter should also include brief abstracts of any referenced documentation to provide an understanding of their relation to this chapter. The bases for individual OSRs and summaries of the OSR program could be extracted from the OSR document. However, a discussion of the process for the derivation of OSRs would need to be developed.

5. It is not recommended that a new chapter on "Human Factors" be created for the FSAR, considering the age of the plant and equipment, current plant operations, and the limited remaining plant lifetime. Although there has been no structured Human Factors review of all equipment and processes, human factors are considered in the PFP Integrated Environmental, Safety and Health Management System (ISMS) Plan. In addition, work processes are routinely subjected to pre-job briefings, Job Hazard Analyses, and subject matter expert reviews. Hands-on operations and worker involvement are a major emphasis of the multi-disciplined work teams, which include management, engineering, operations, and safety personnel.

Current plans call for these recommendations to be addressed in the next PFP FSAR annual update (FY 2001). 


\subsection{REFERENCES}

$\underline{\text { References within text of document }}$

BWHC, 1999, Plutonium Finishing Plant Final Safety Analysis Report, HNF-SD-CP-SAR-021, Rev 1, B\&W Hanford Company, Richland, Washington.

NRC, 1976, Standard Format and Content of License Applications for Plutonium Processing and Fuel Fabrication Plants, Regulatory Guide 3.39, NUREG-0010, U.S. Nuclear Regulatory Commission, Washington, D.C.

DOE, 1992, Nuclear Safety Analysis Reports, DOE Order 5480.23, U.S. Department of Energy, Washington, D.C.

DOE, 1994, Preparation Guide for U.S. Department of Energy Nonreactor Nuclear Facility Safety Analysis Reports, DOE-STD-3009-94, U.S. Department of Energy, Washington, D.C.

FH, 2000, Plutonium Finishing Plant Operational Safety Requirements, WHC-SD-CP-OSR-010, Revision 0-M, Fluor Hanford, Inc., Richland, Washington.

\section{References within Table 1}

DOE Order 430.1A, Life Cycle Asset Management, dated November 14, 1998, U.S. Department of Energy, Washington, D.C.

DOE Order 5480.19, Change 1, Conduct of Operations Requirements for DOE Facilities, dated May 18, 1992, U.S. Department of Energy, Washington, D.C.

DOE Order 6430.1A, General Design Criteria, dated April 6, 1989, U.S. Department of Energy, Washington, D.C.

FSP-PFP-0760, Rev. 13, Change 0, Authorization Listing of the Emergency Response Organization for PFP, dated April 5, 2000, B\&W Hanford Company, Richland, Washington.

FSP-PFP-0821, PFP Conduct of Operations, B\&W Hanford Company, Richland, Washington.

FSP-PFP-5-8, Plutonium Finishing Plant Administration, B\&W Hanford Company, Richland, Washington.

FSP-PFP-1121, Plutonium Finishing Plant Training Administration, B\&W Hanford Company, Richland, Washington. 
HNF-IP-0263-PFP, Building Emergency Plan for the Plutonium Finishing Plant Complex, B\&W Hanford Company, Richland, Washington.

HNF-MP-0031, Rev. 3, "Integrated Environment, Safety, and Health Management System Description, Fluor Hanford, Inc., Richland, Washington.

HNF-PRO-587, Rev. 1, Laboratory Safety, dated October 20, 1999, Fluor Hanford, Inc., Richland, Washington.

HNF-PRO-1819, Rev. 4, PHMC Engineering Requirements, dated January 24, 2000, Fluor Hanford, Inc., Richland, Washington.

HNF-PRO-2258, Rev. 0, Chemical Management, dated August 31, 1998, Fluor Hanford, Inc., Richland, Washington.

HSRCM-1, Hanford Site Radiological Control Manual, DOE/RL-96-109, Rev. 0, DOE Richland Operations Office, Richland, Washington.

ZAP-000-002, Rev. B, Change 0, PFP Configuration Management Plan, dated July 8, 1999, B\&W Hanford Company, Richland, Washington.

ZAP-000-010, Rev. A, Mod 2, "PFP Chemical Hygiene Plan," dated March 1, 2000, B\&W Hanford Company, Richland, Washington. 
HNF-6533 Rev. 0

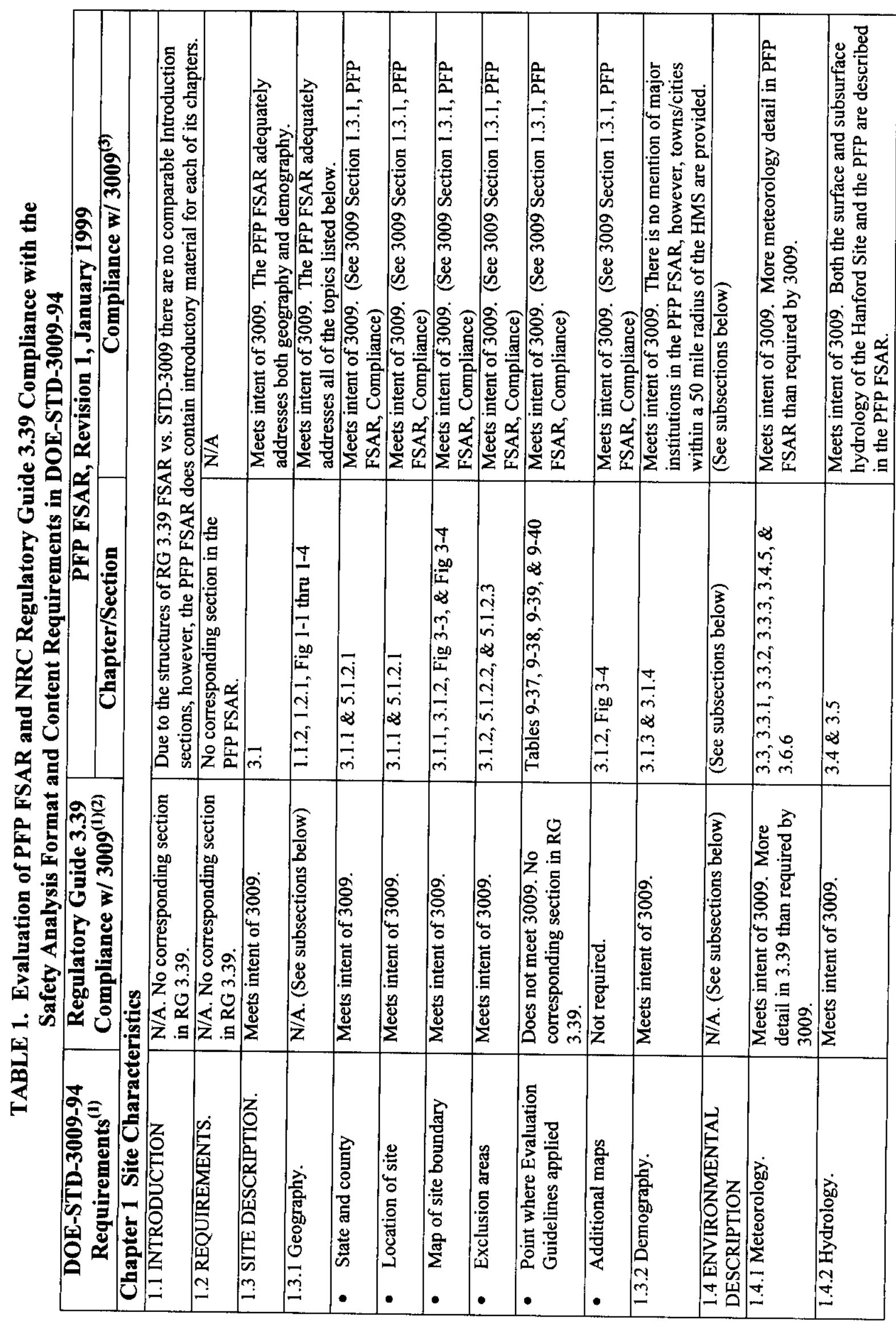


HNF-6533 Rev. 0

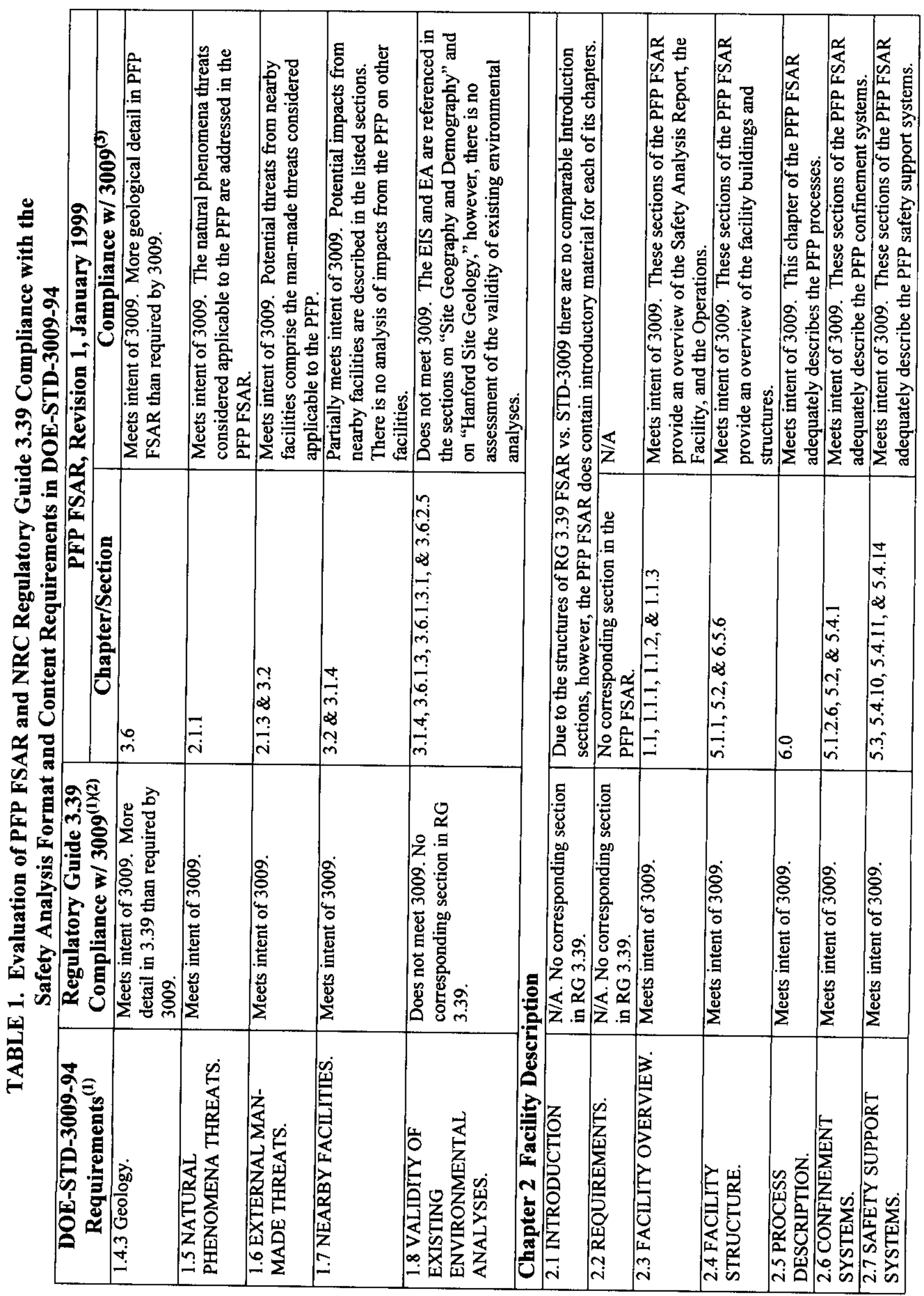


HNF-6533 Rev. 0

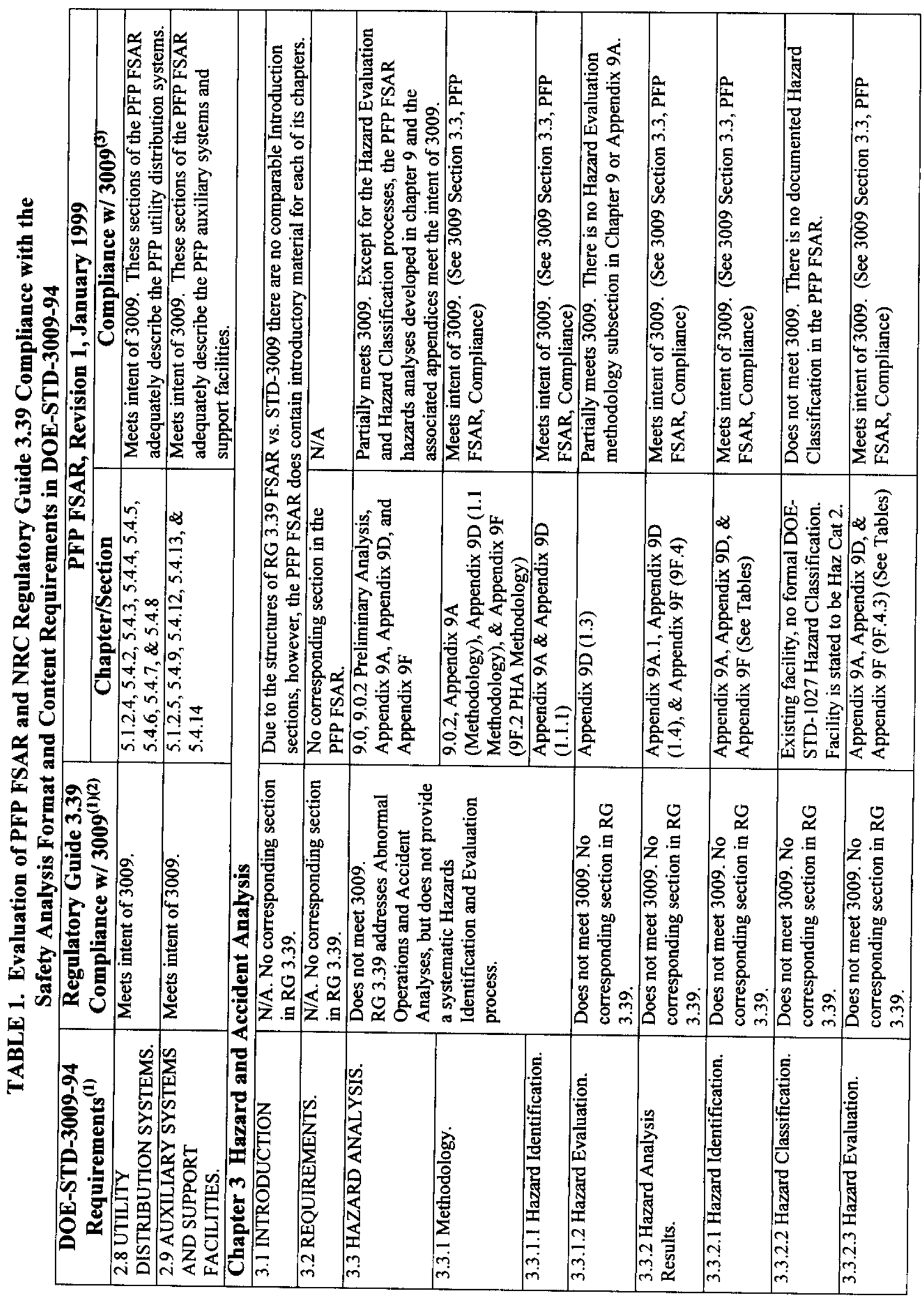


HNF-6533 Rev. 0

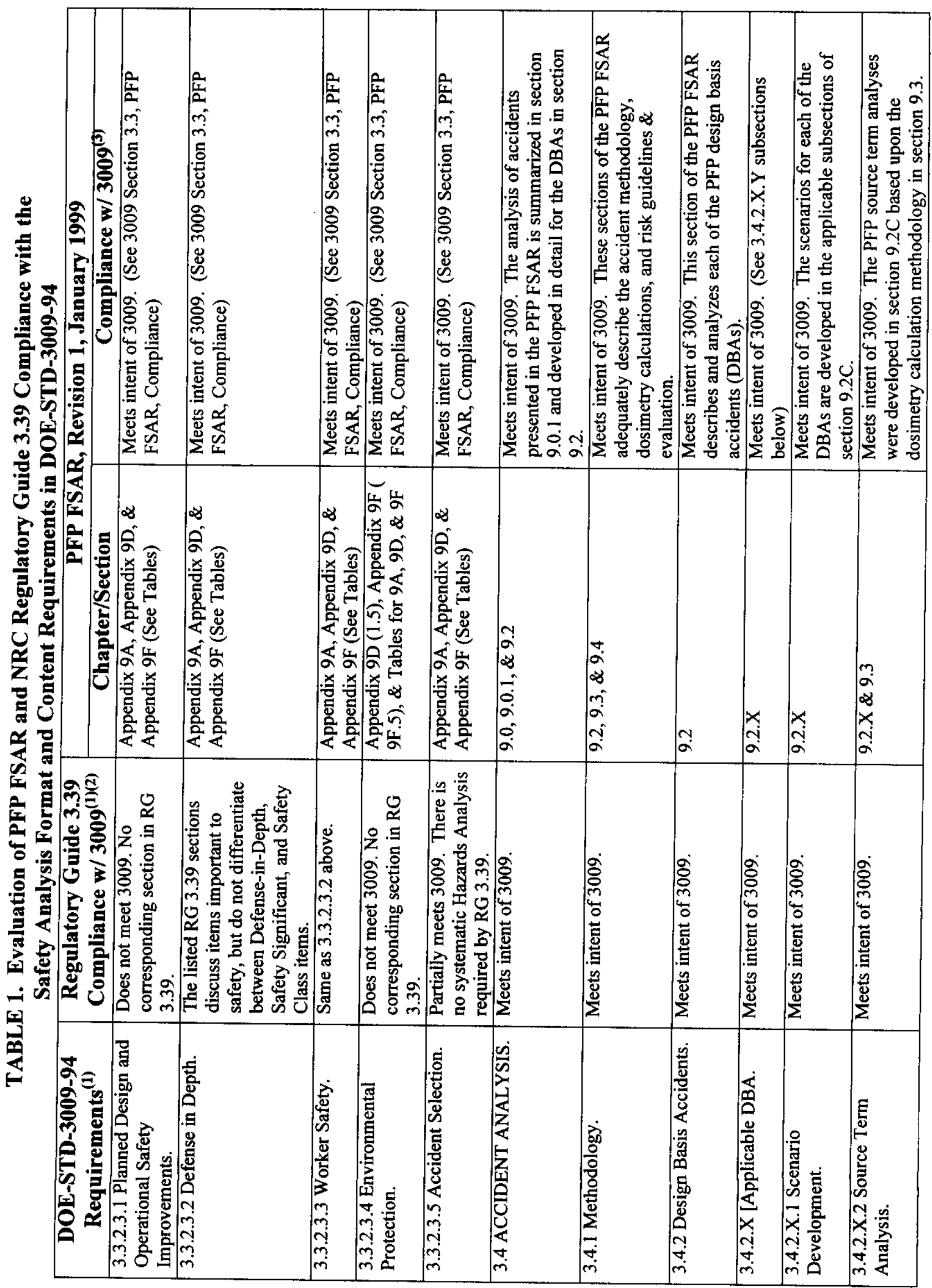


HNF-6533 Rev. 0

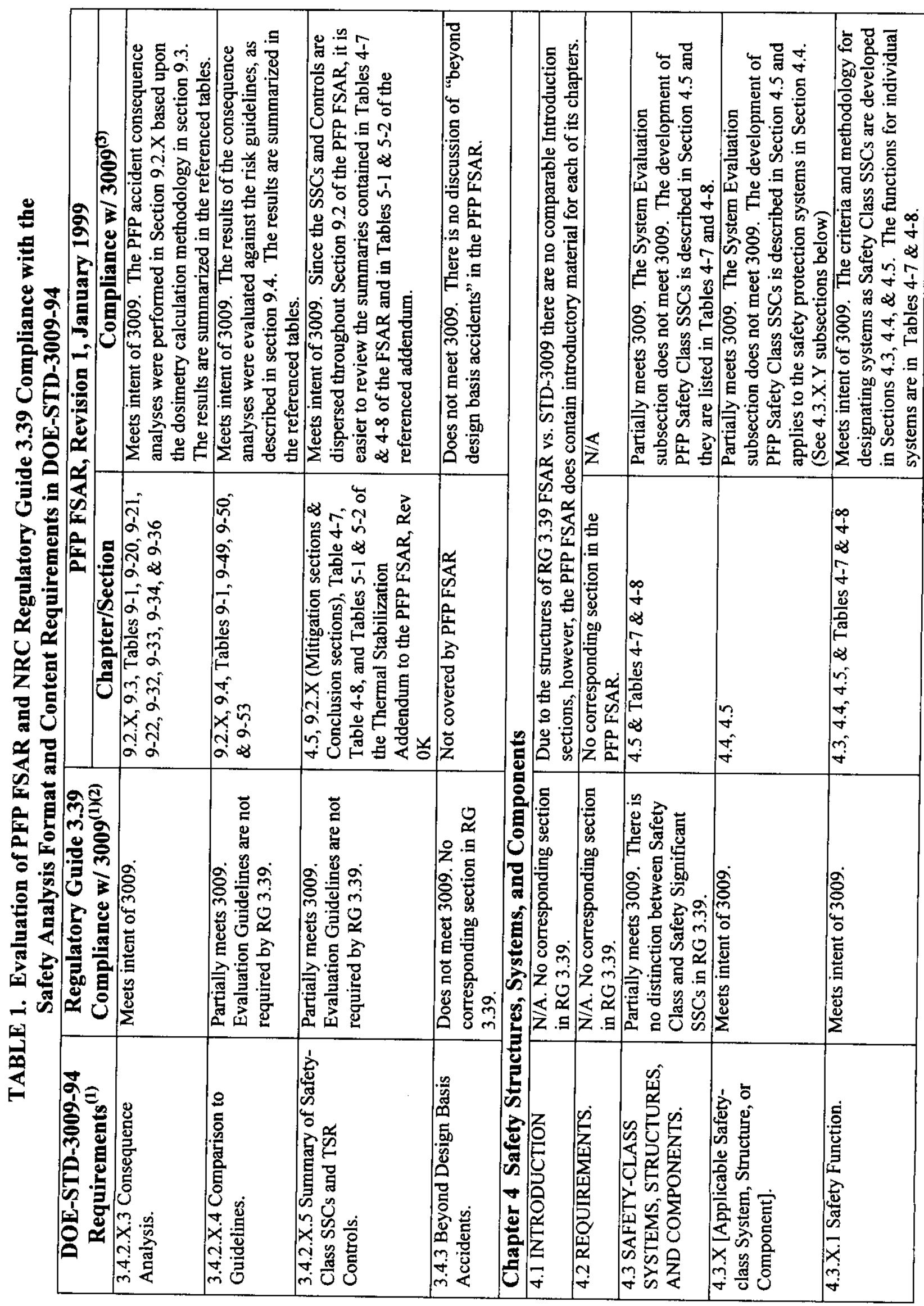


HNF-6533 Rev. 0

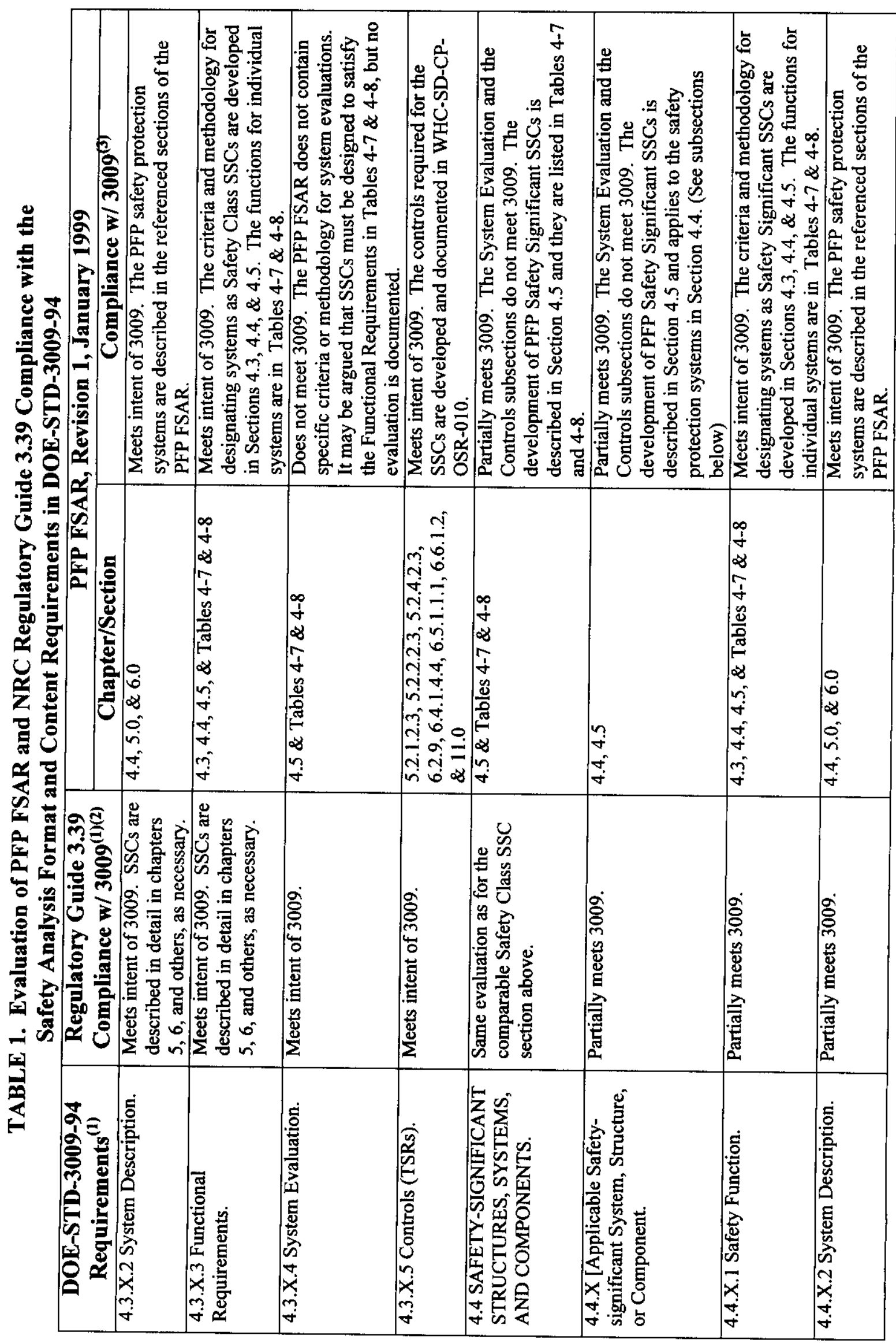


HNF-6533 Rev. 0

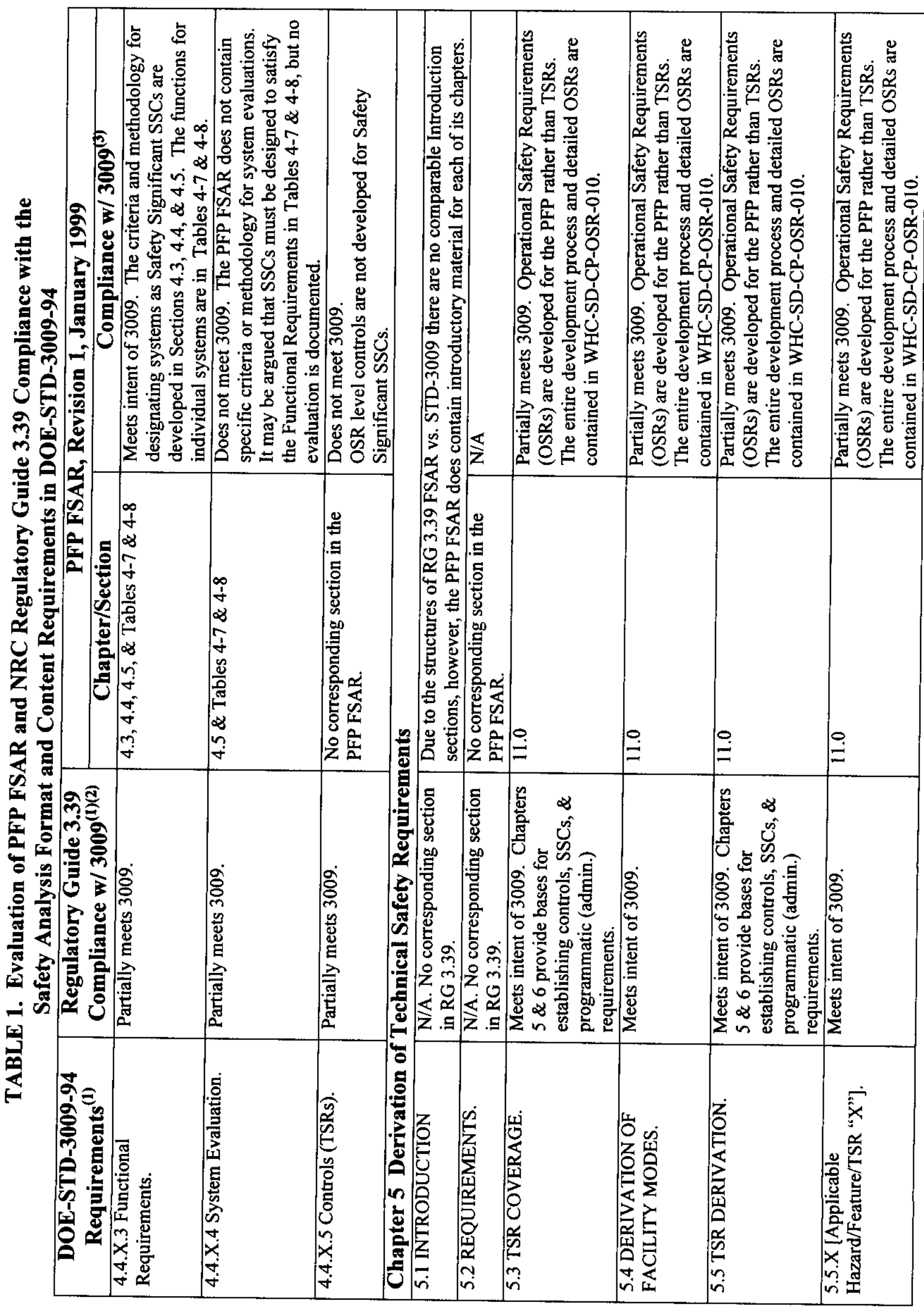


HNF-6533 Rev. 0

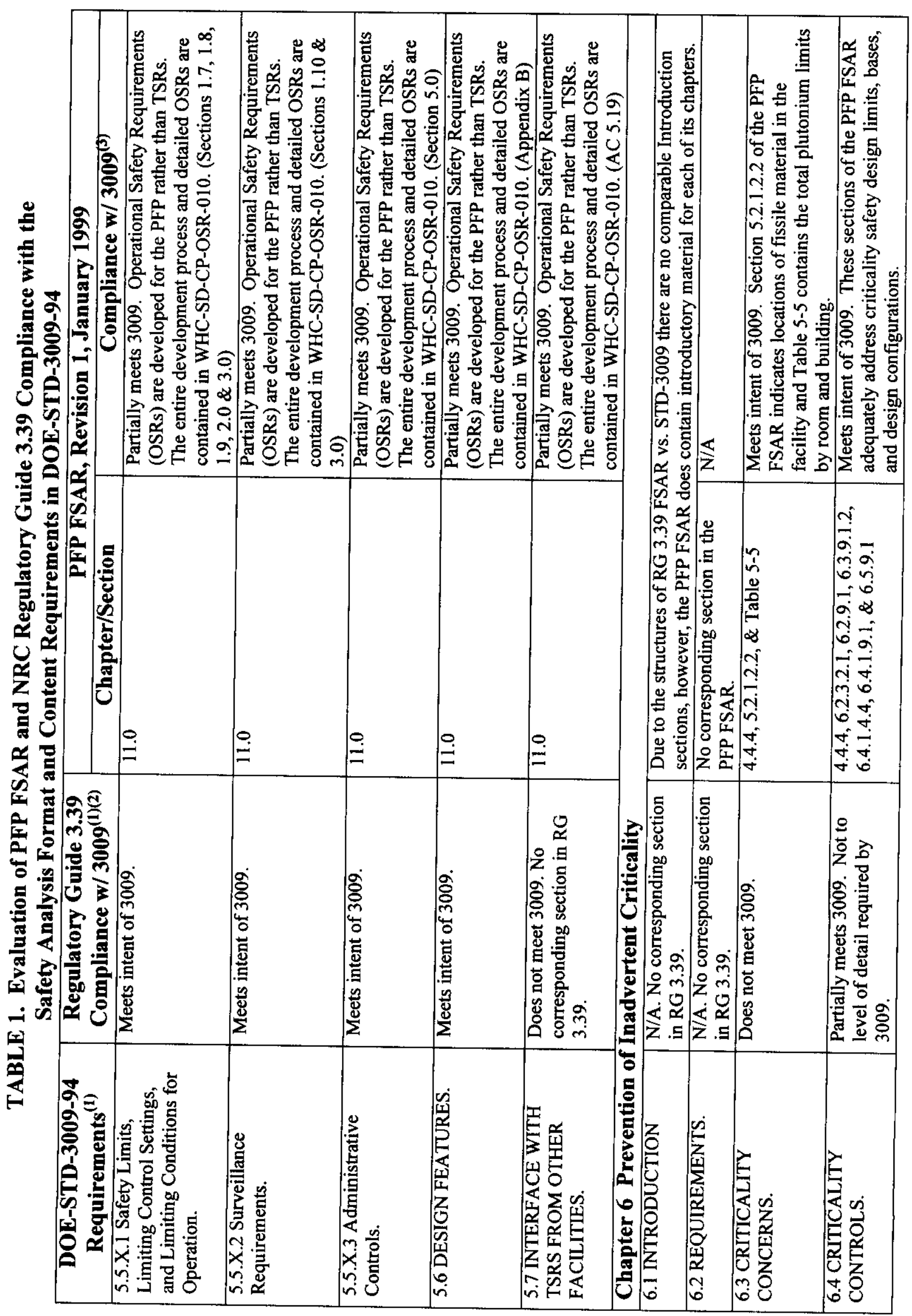


HNF-6533 Rev. 0

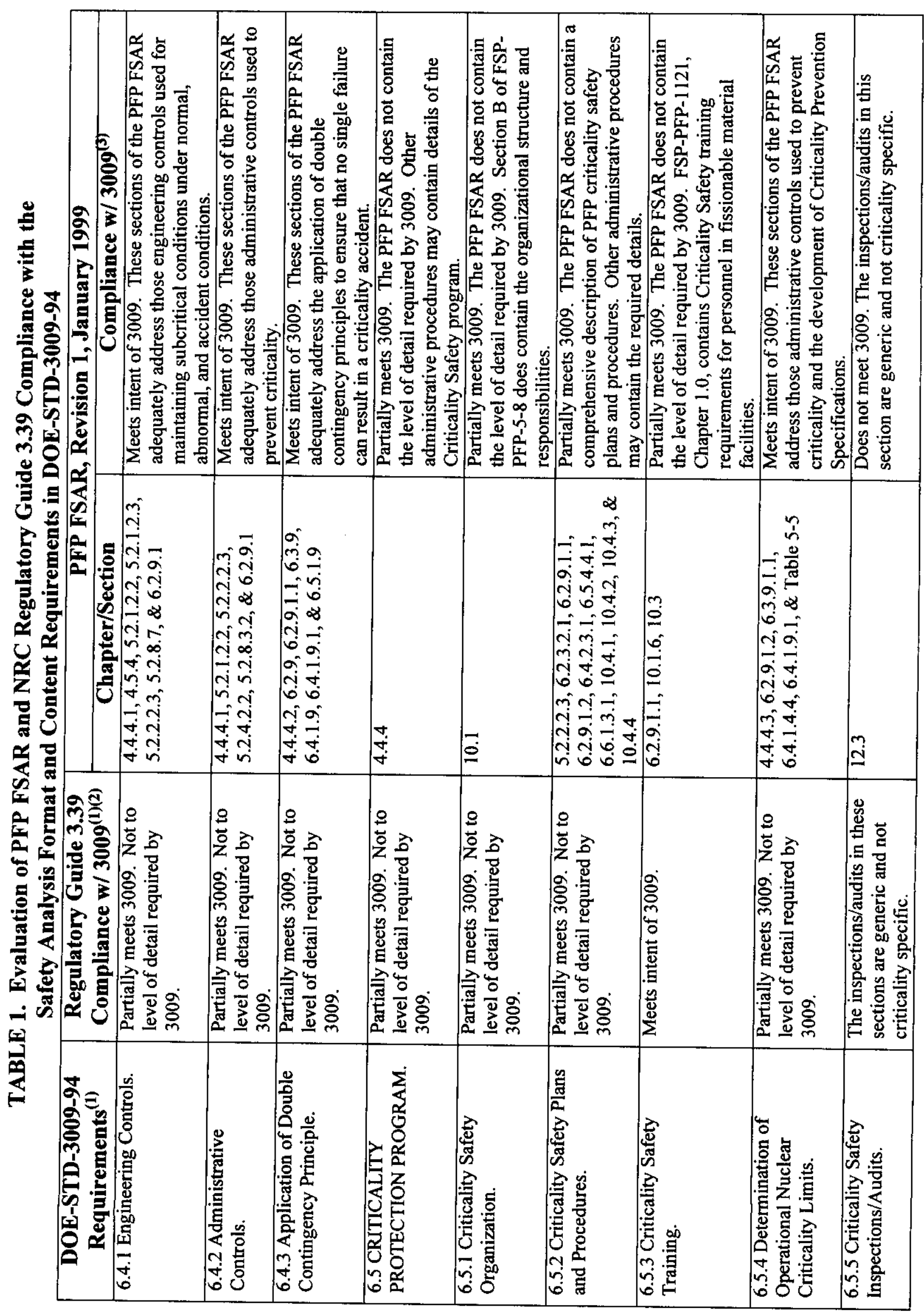


HNF-6533 Rev. 0

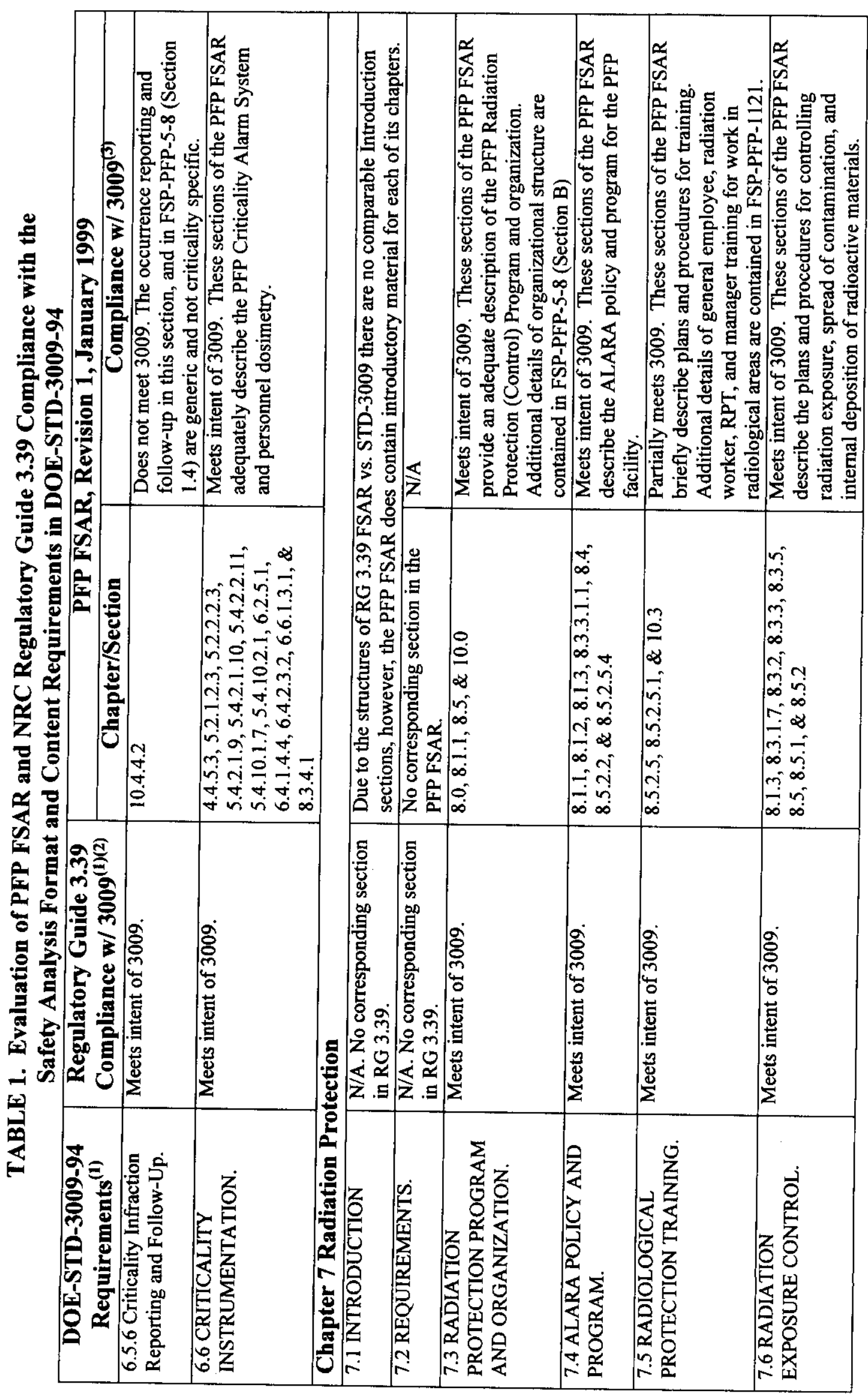


HNF-6533 Rev. 0

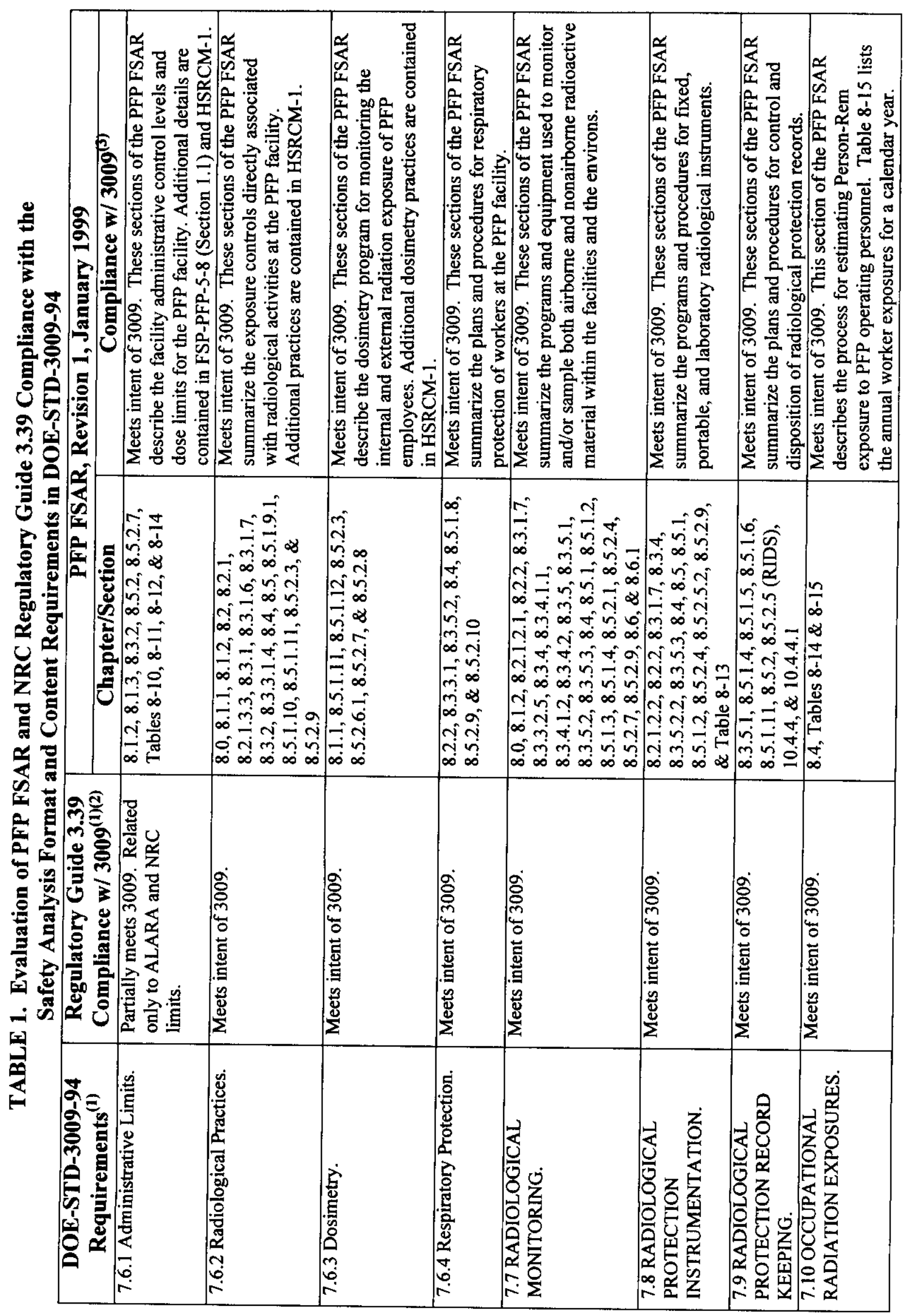


HNF-6533 Rev. 0

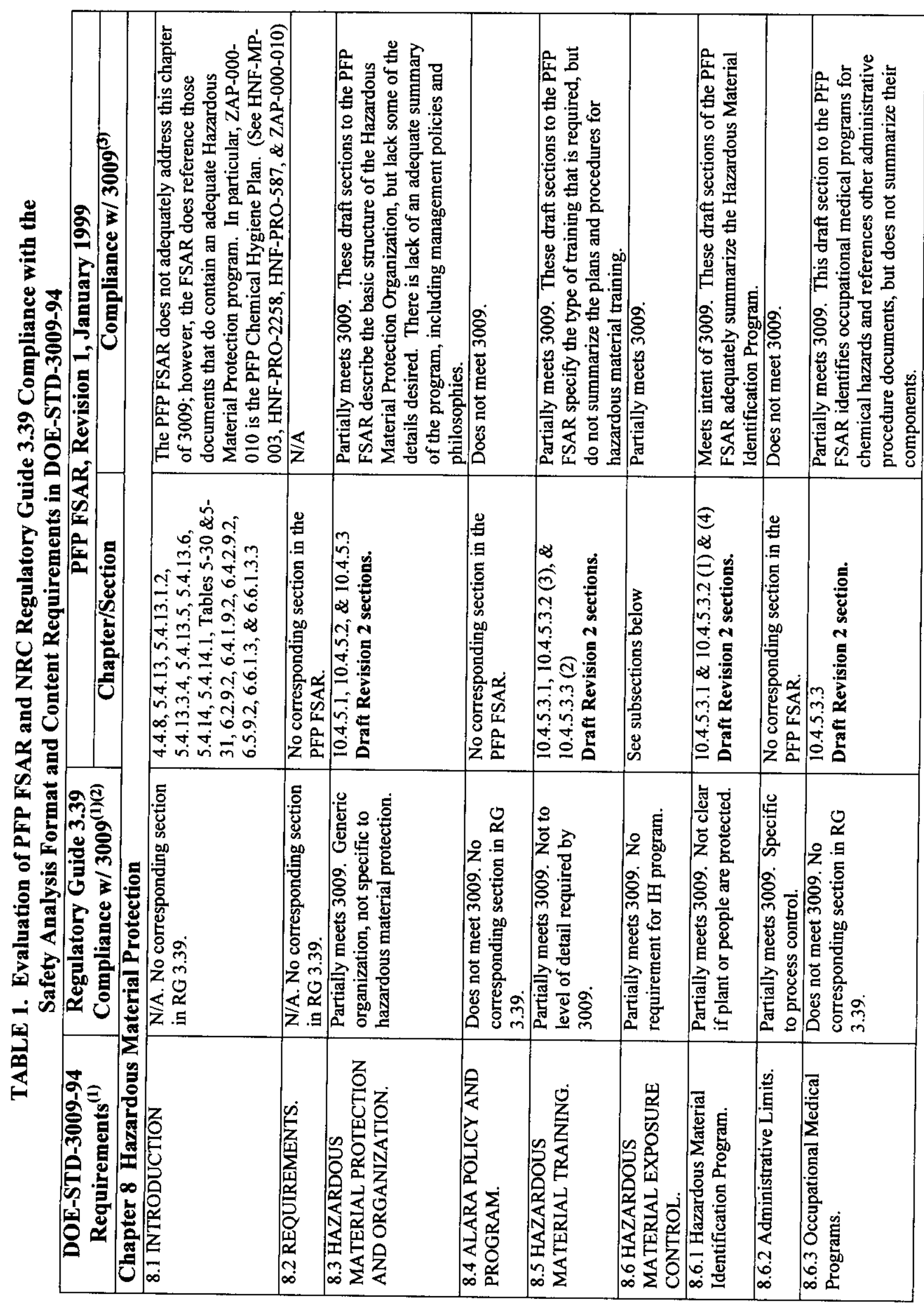


HNF-6533 Rev. 0

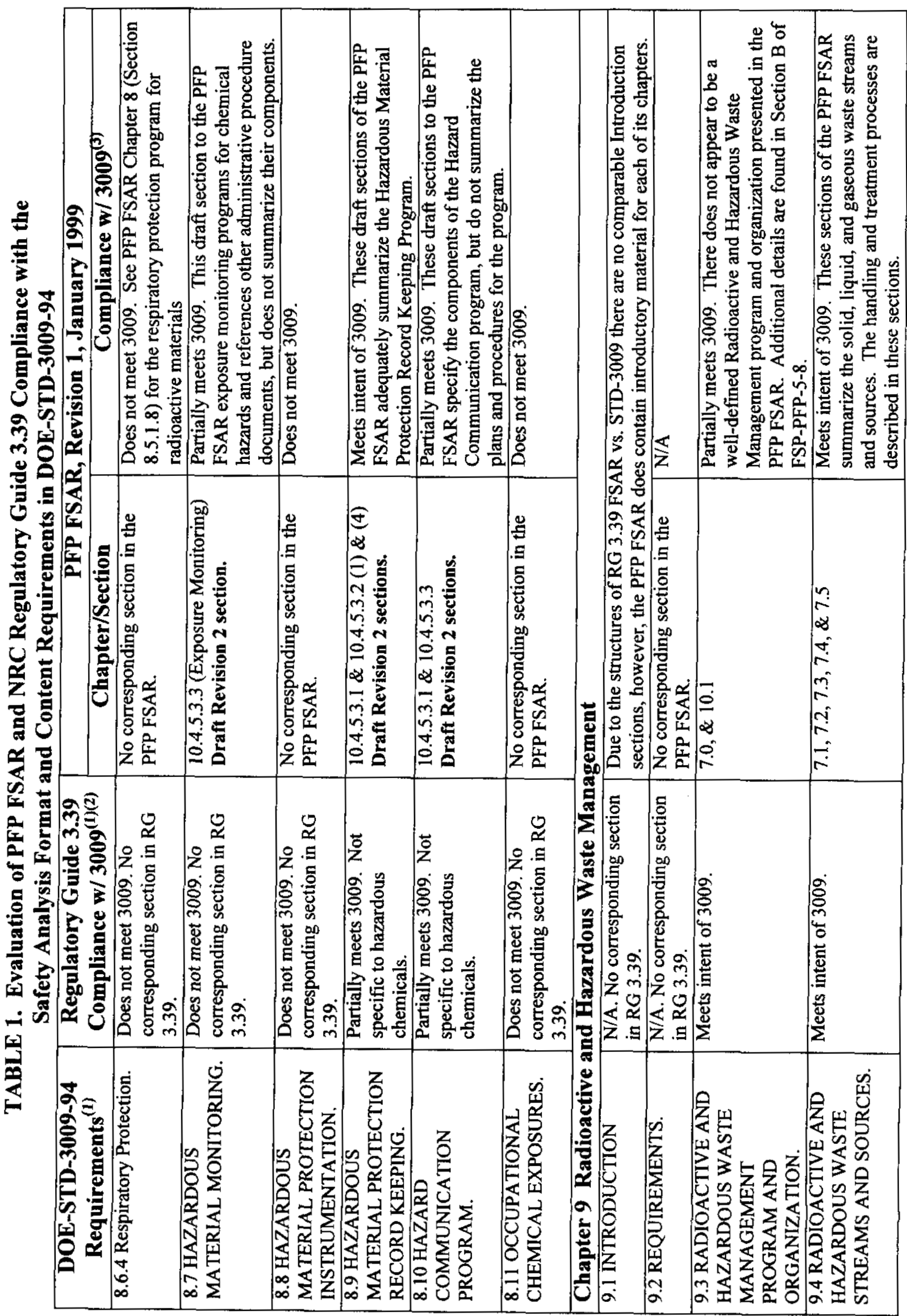


HNF-6533 Rev. 0

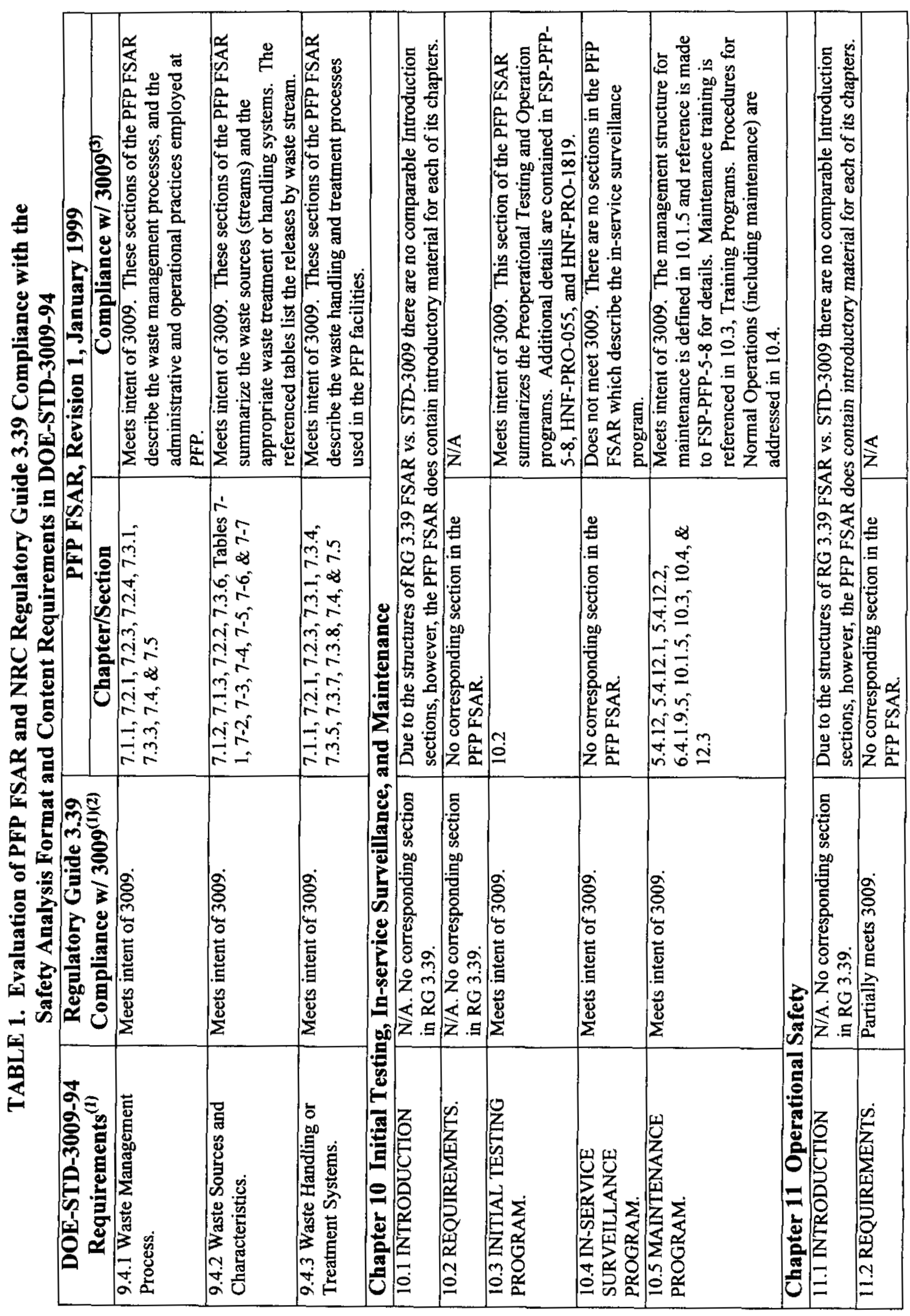


HNF-6533 Rev. 0

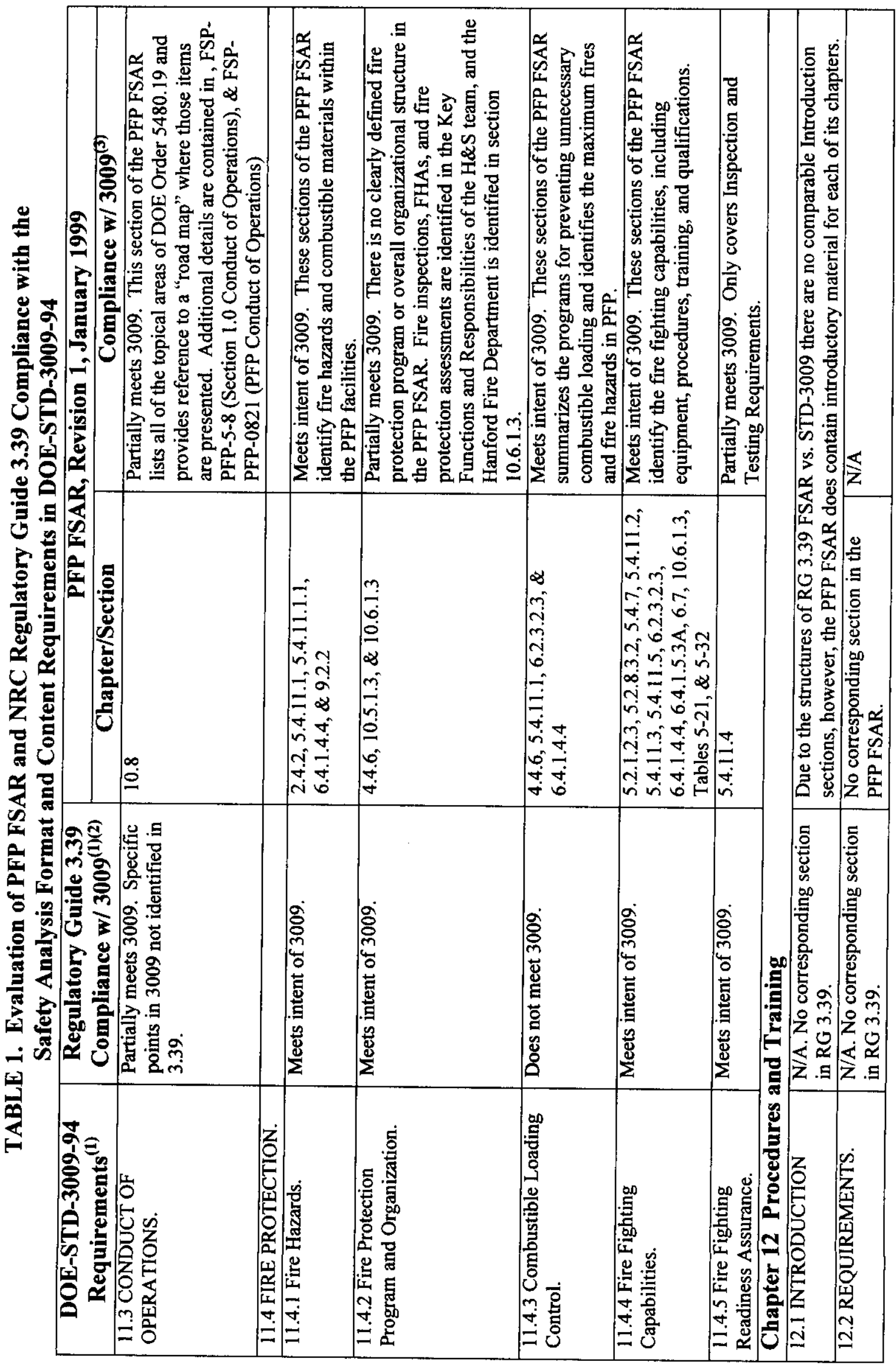


HNF-6533 Rev. 0

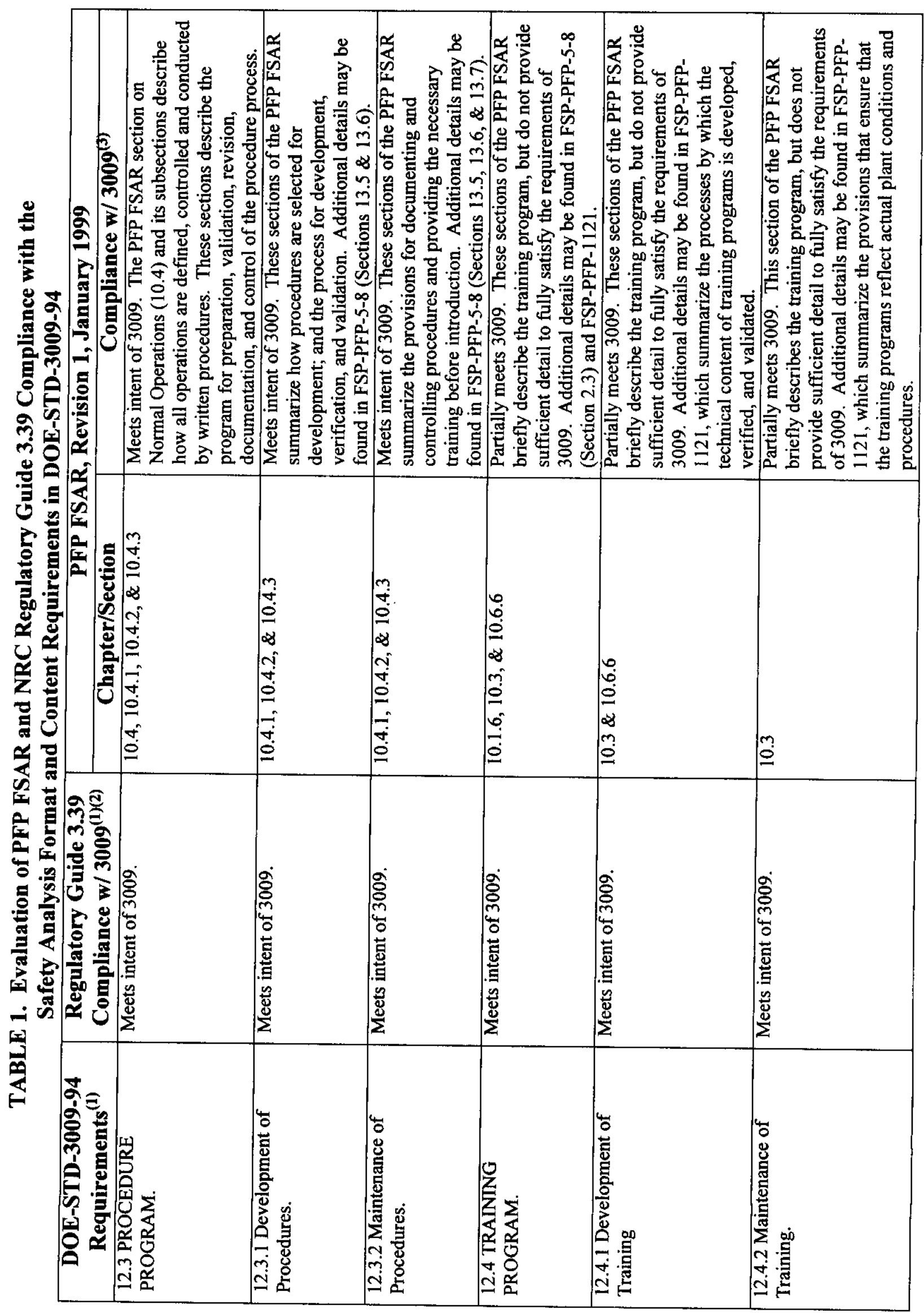


HNF-6533 Rev. 0

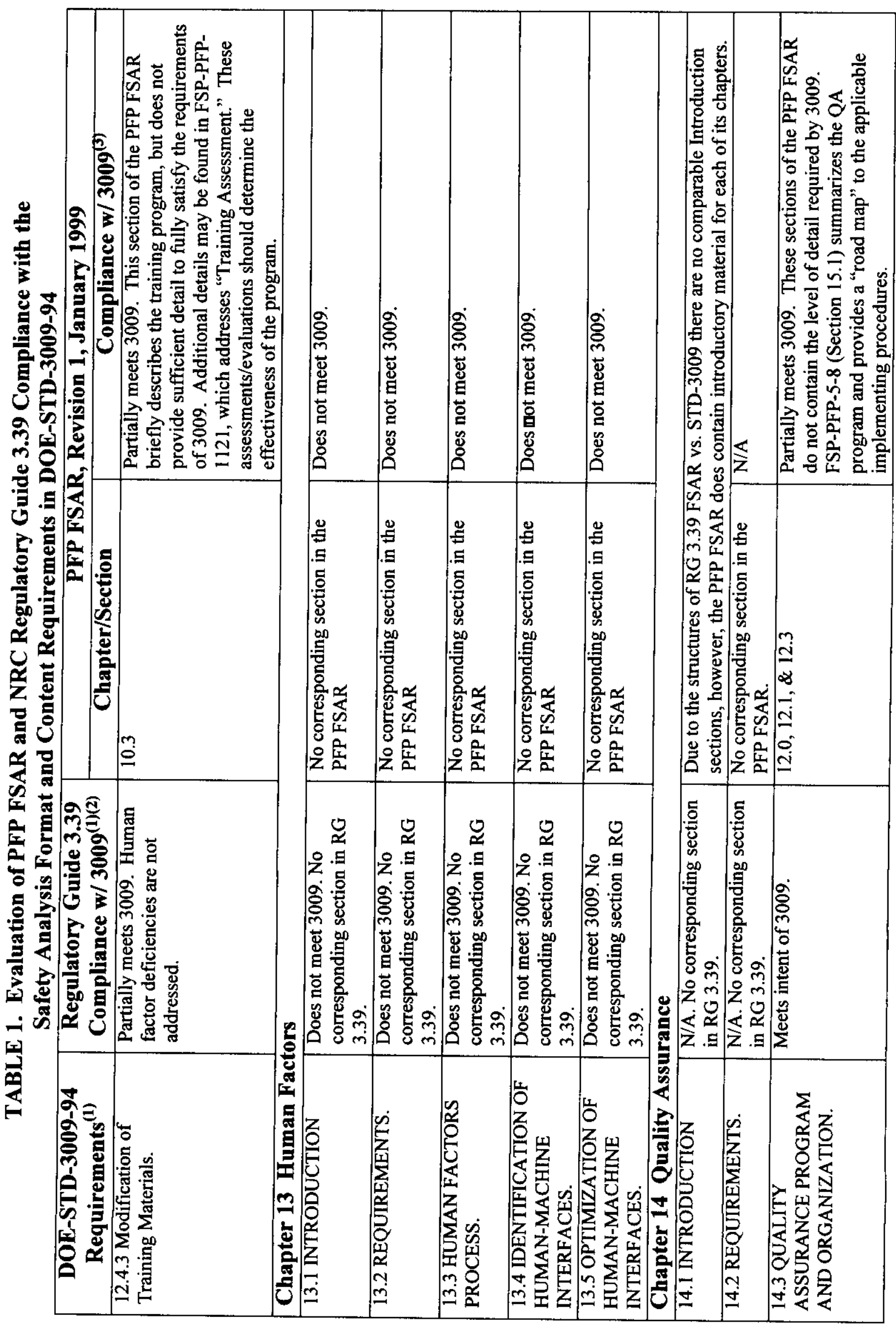


HNF-6533 Rev. 0

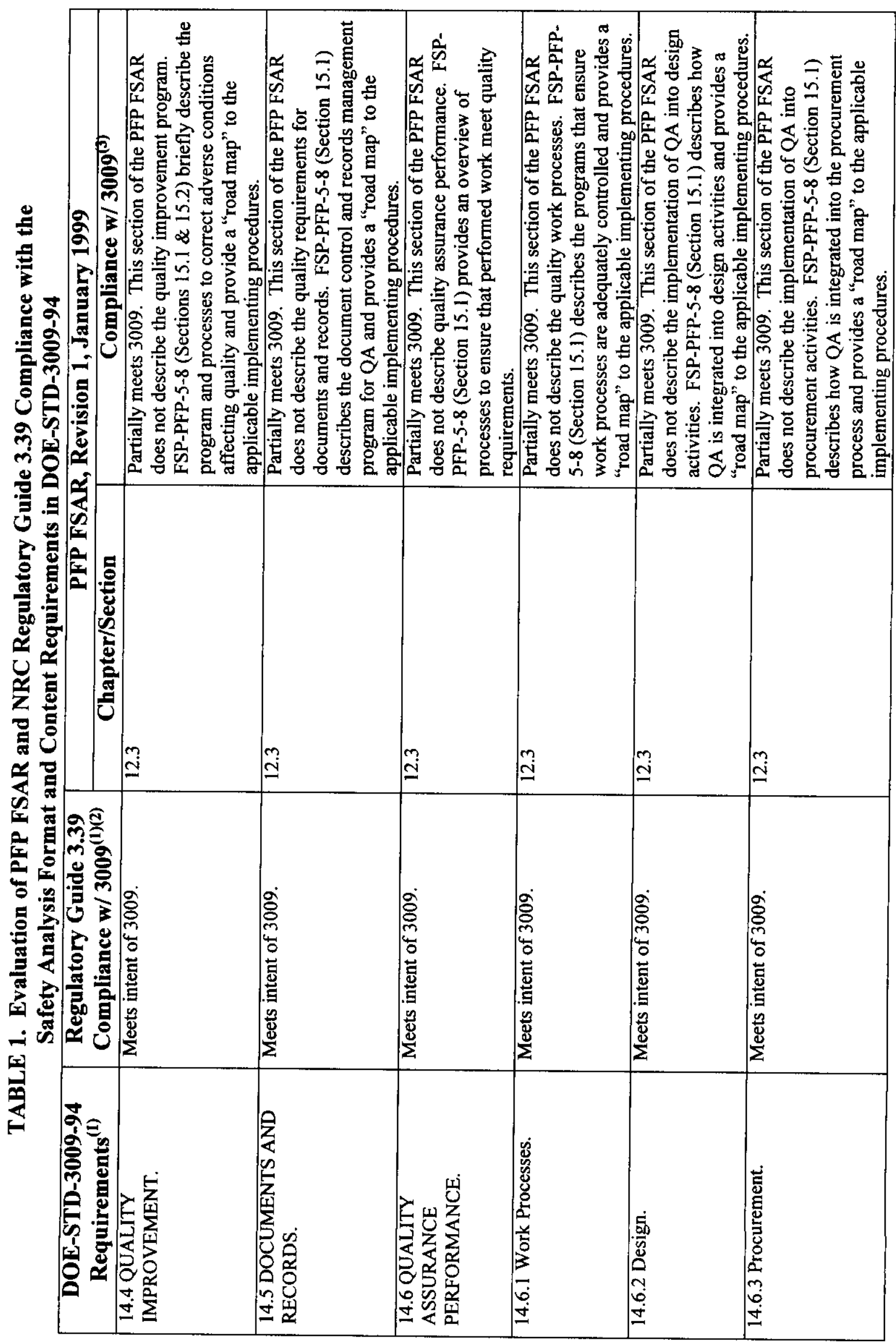


HNF-6533 Rev. 0

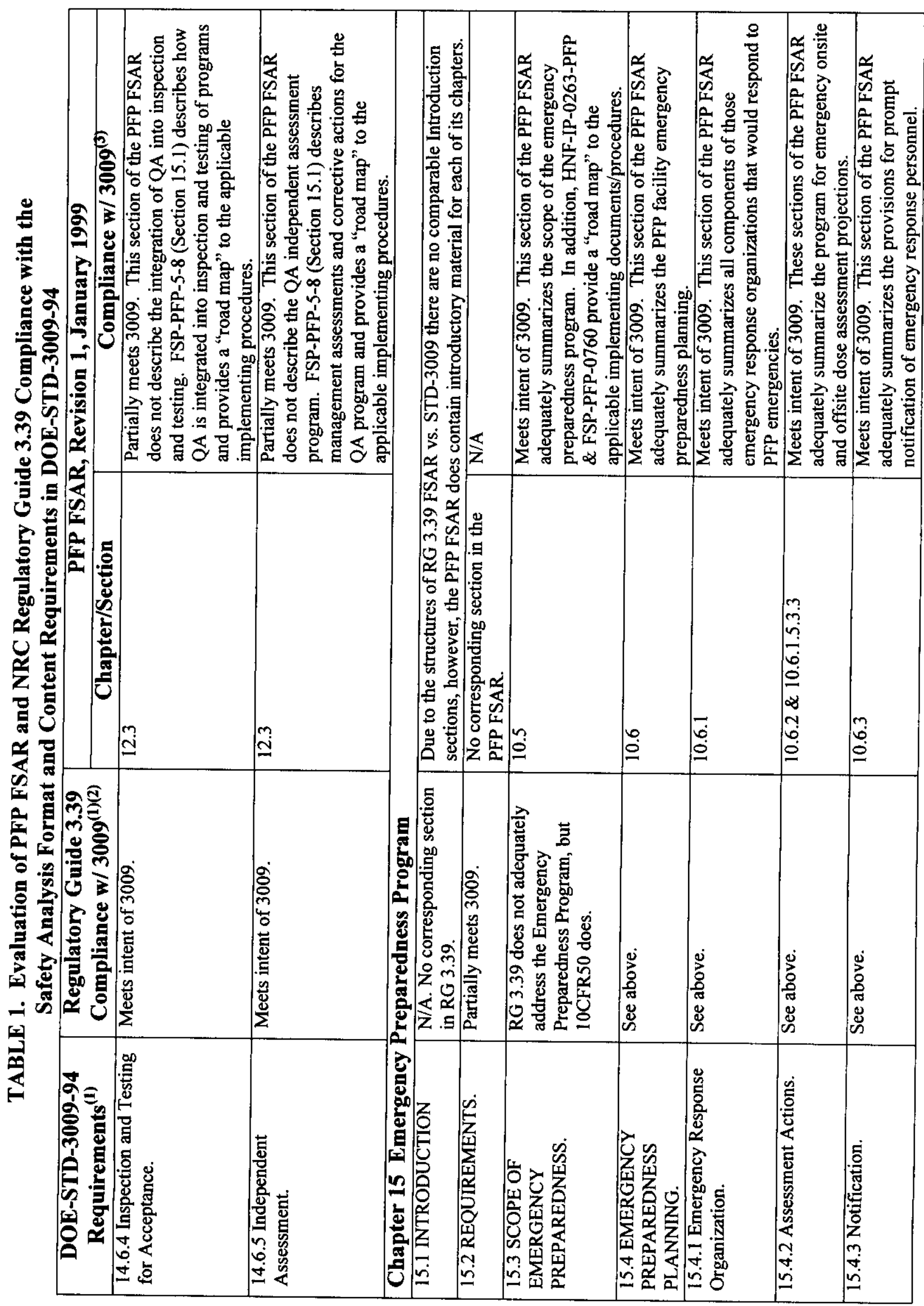


HNF-6533 Rev. 0

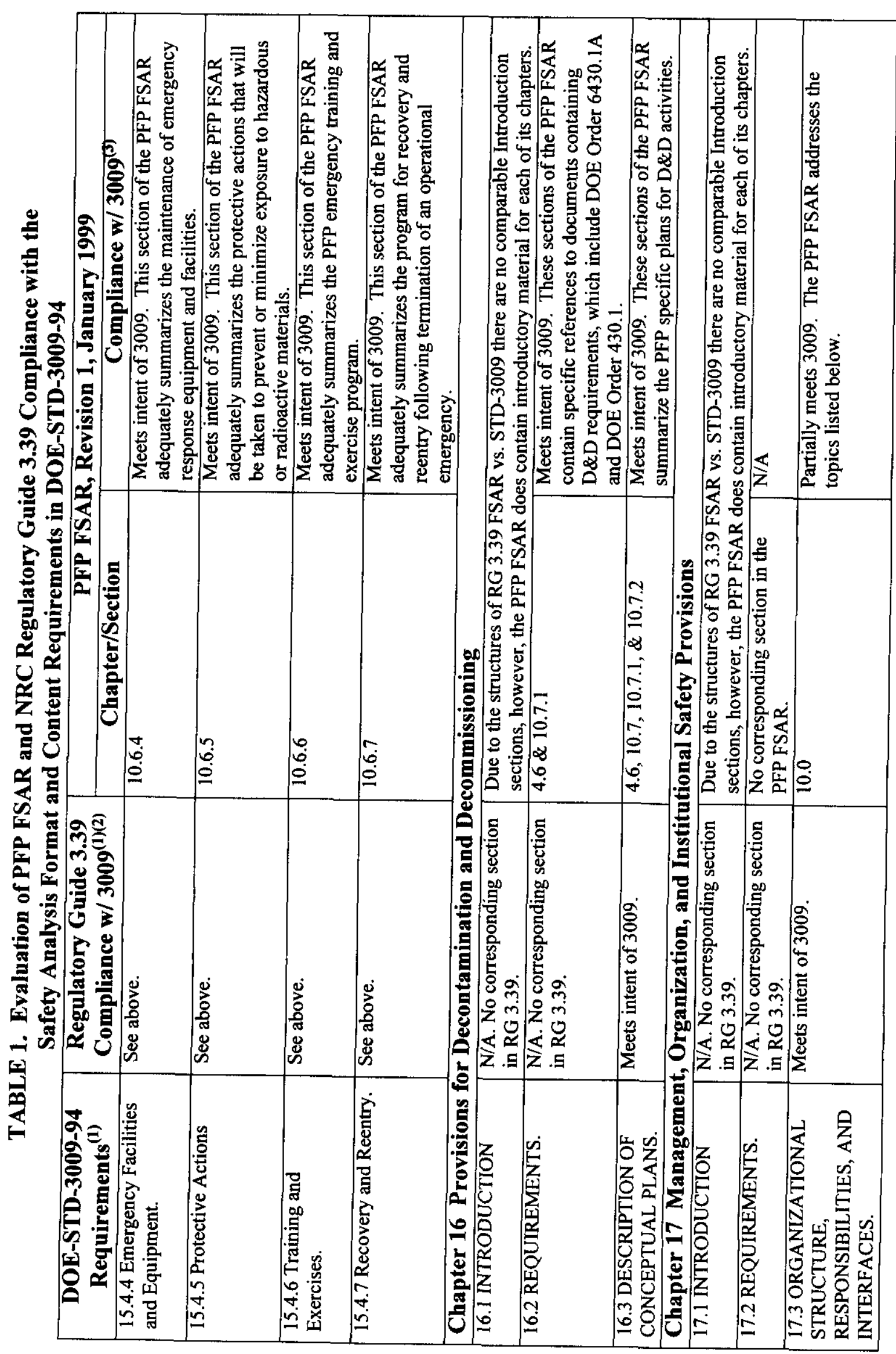


HNF-6533 Rev. 0

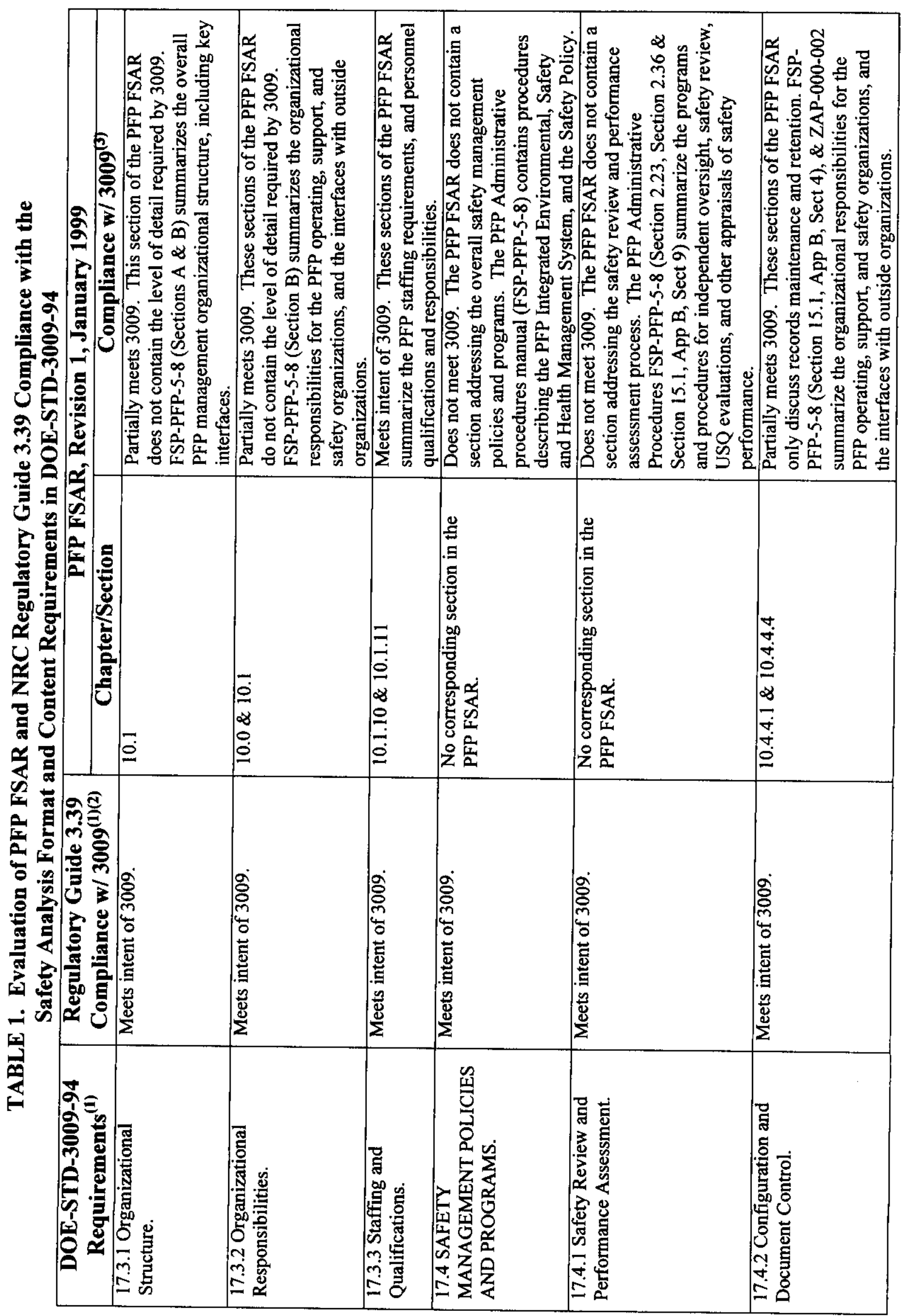


HNF-6533 Rev. 0

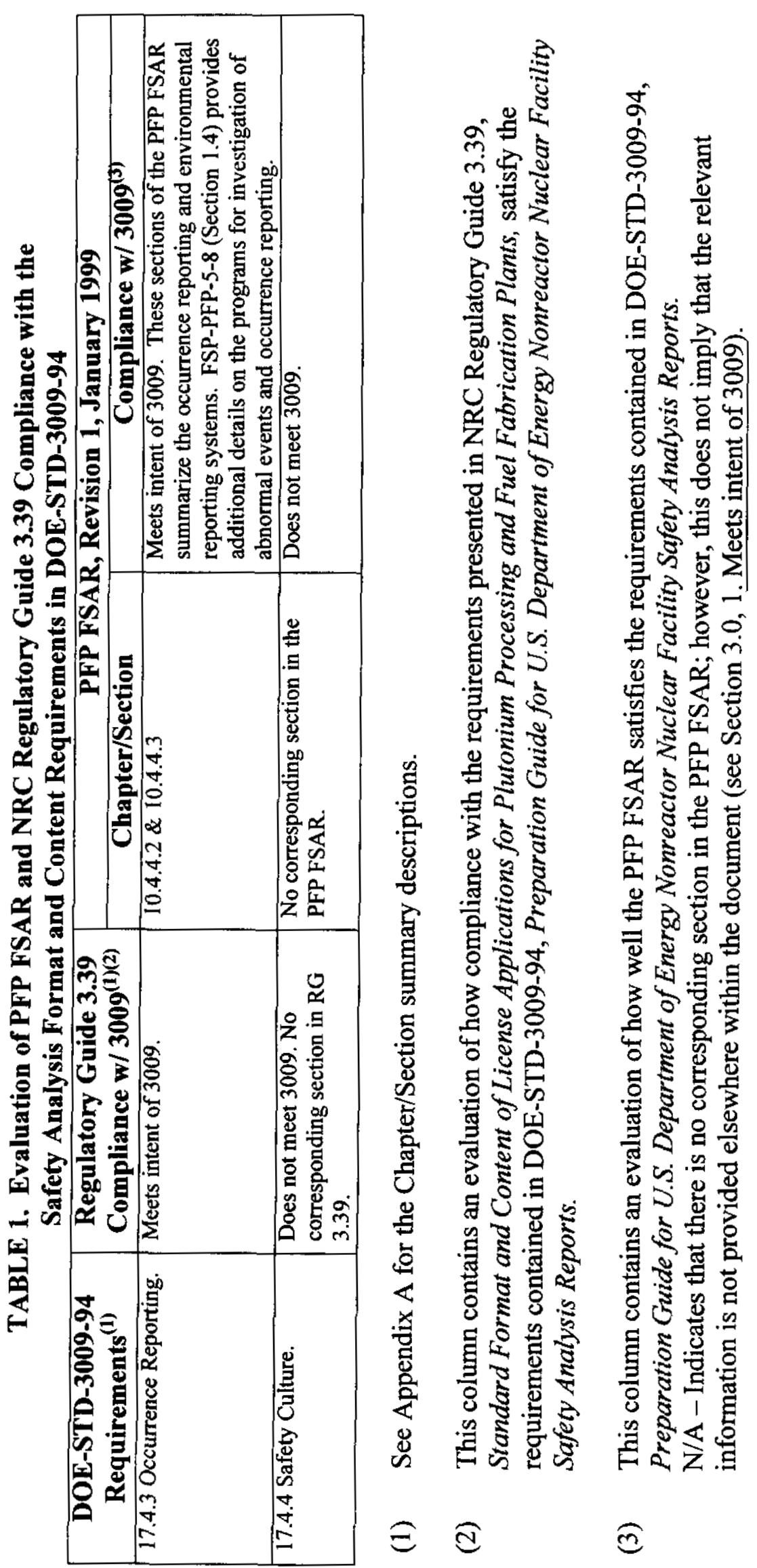


HNF-6533 Rev. 0

\section{Appendix A}

Comparison Between Safety Analysis Format Requirements

Contained in DOE-STD-3009-94 and NRC Regulatory Guide 3.39 
HNF-6533 Rev. 0

This page intentionally left blank. 
HNF-6533 Rev. 0

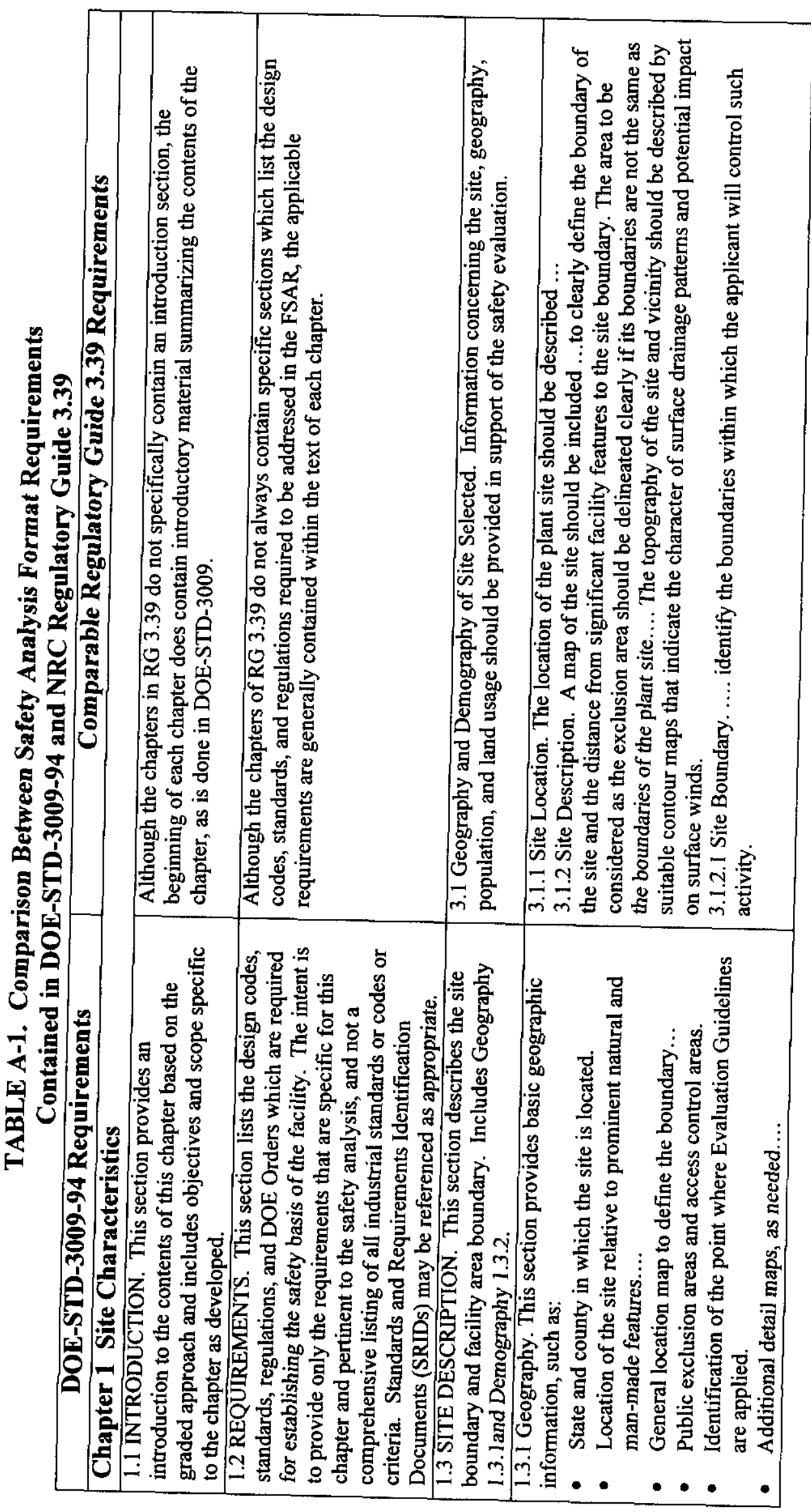


HNF-6533 Rev. 0

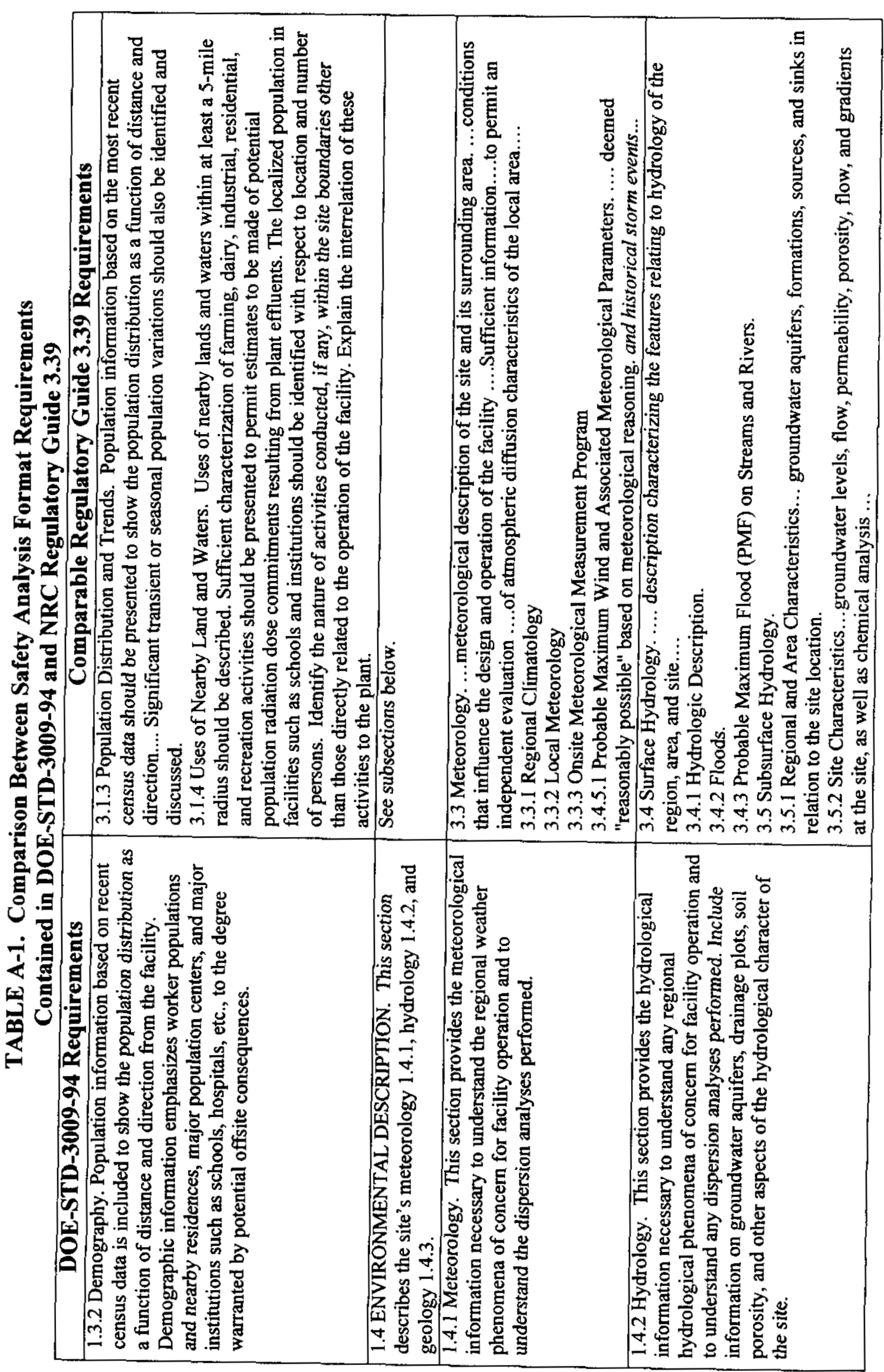


HNF-6533 Rev. 0

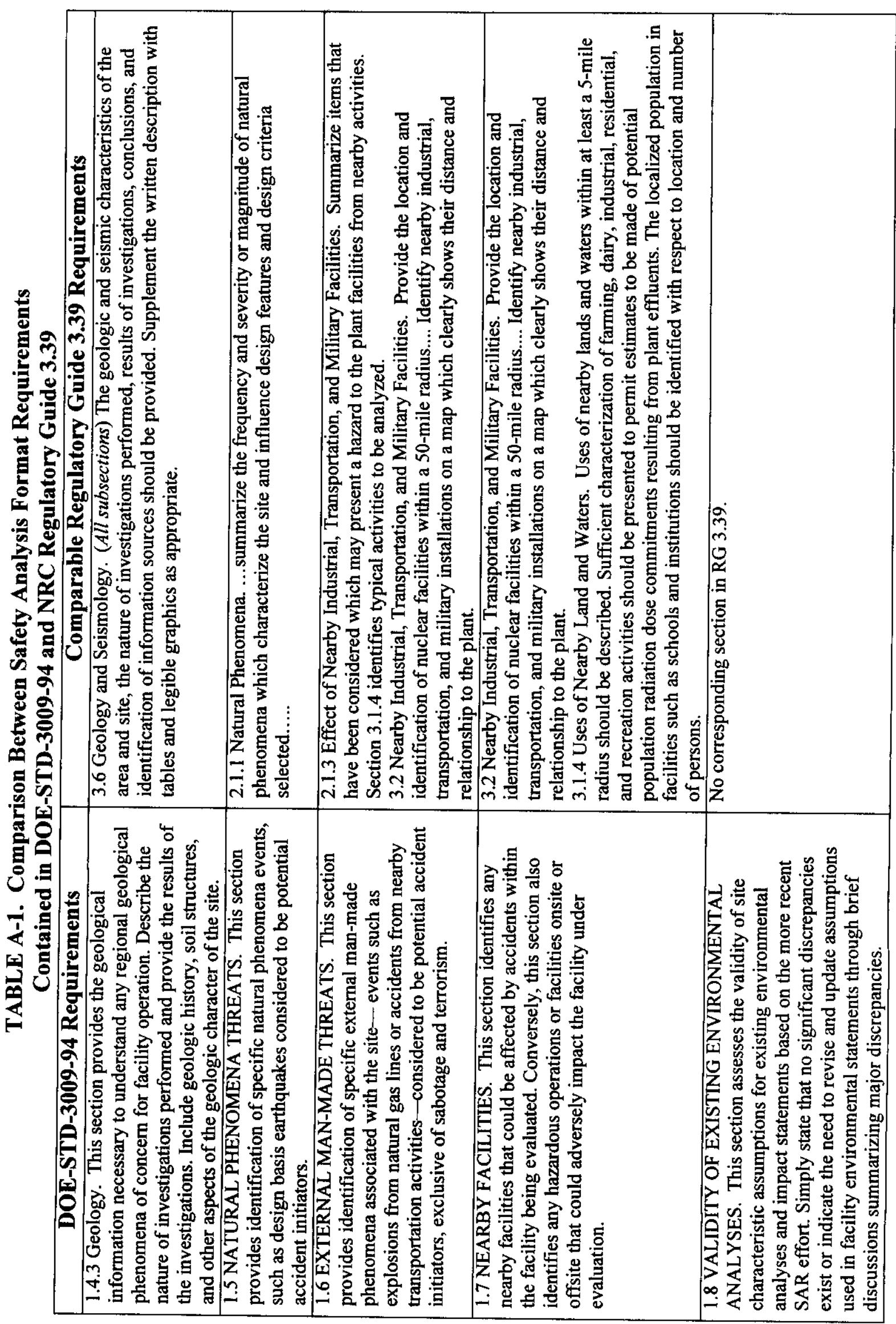


HNF-6533 Rev. 0

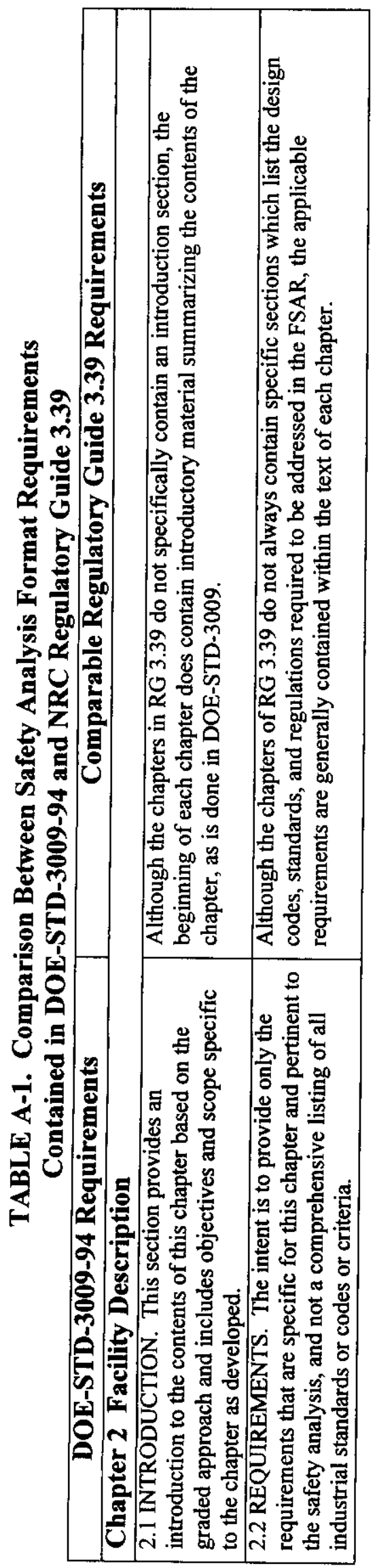




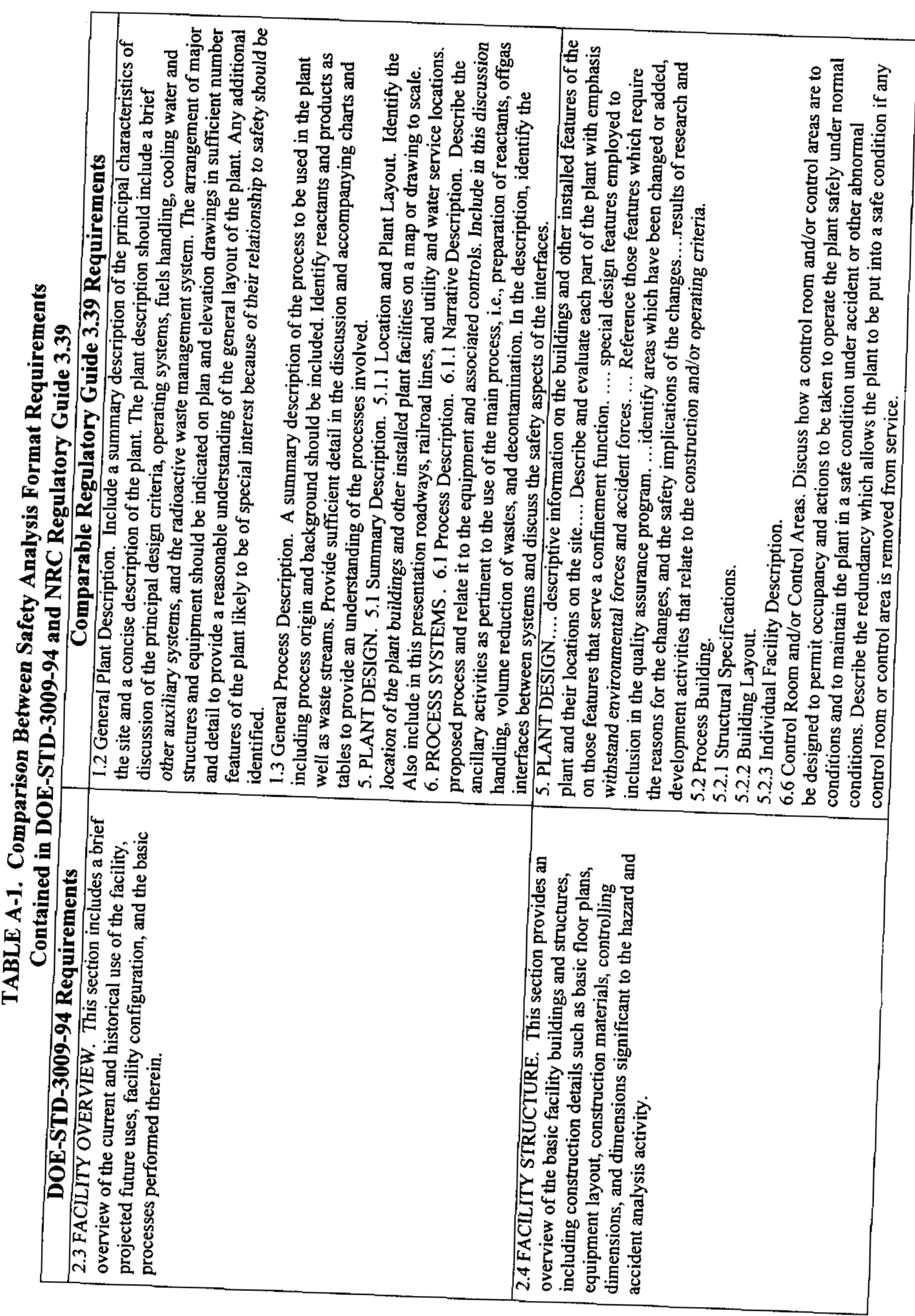


HNF-6533 Rev. 0

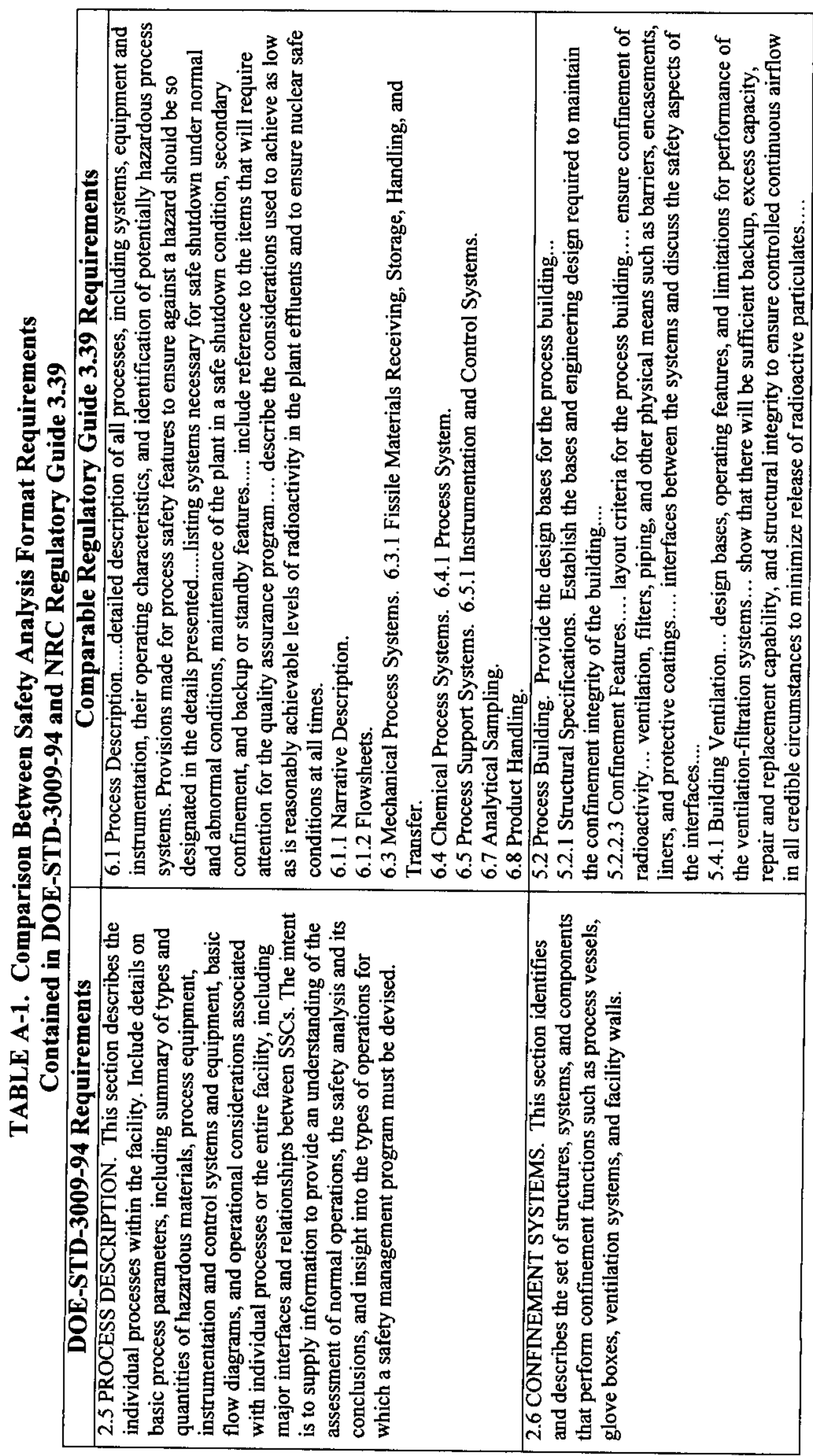


HNF-6533 Rev. 0

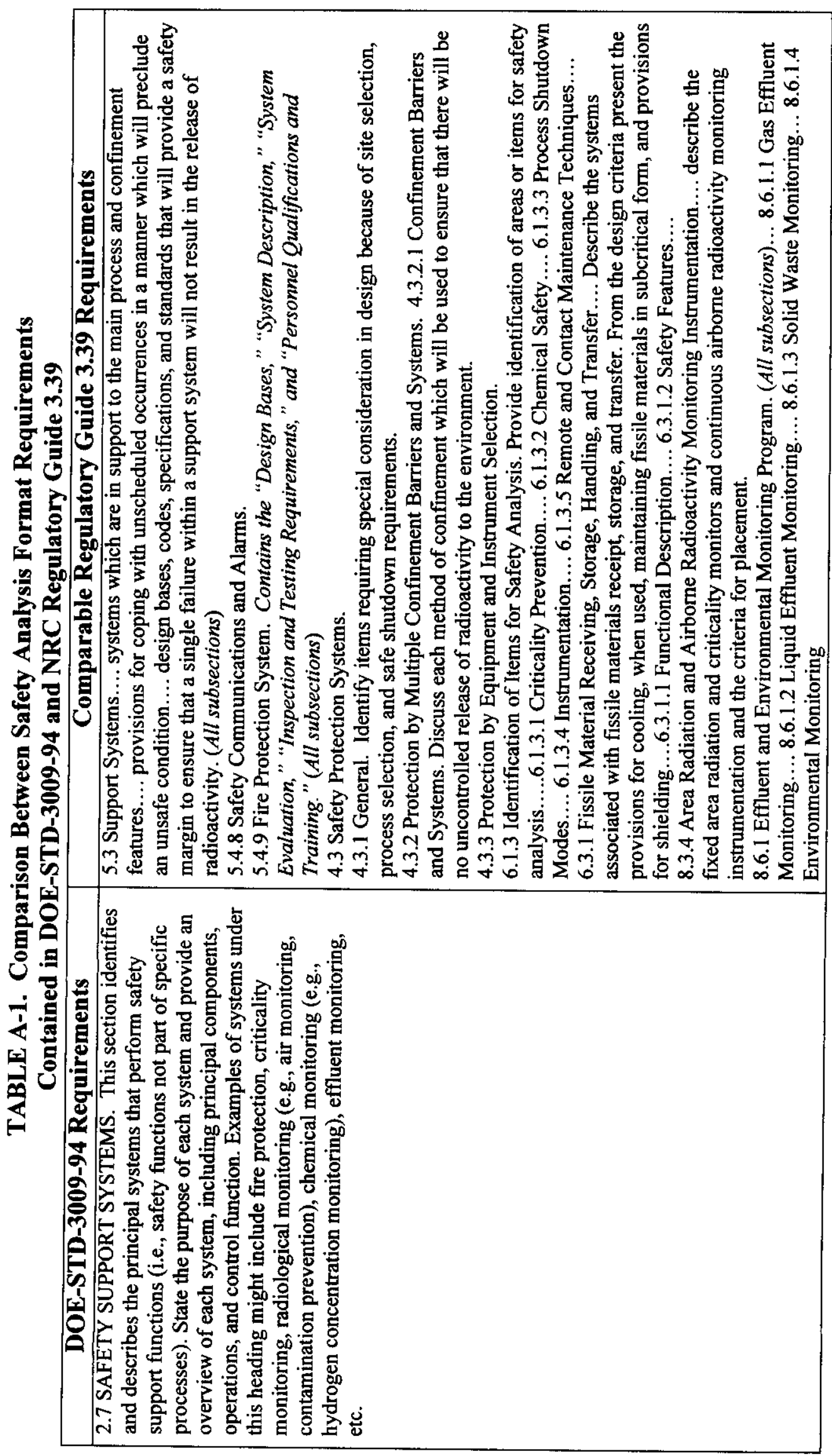


HNF-6533 Rev. 0

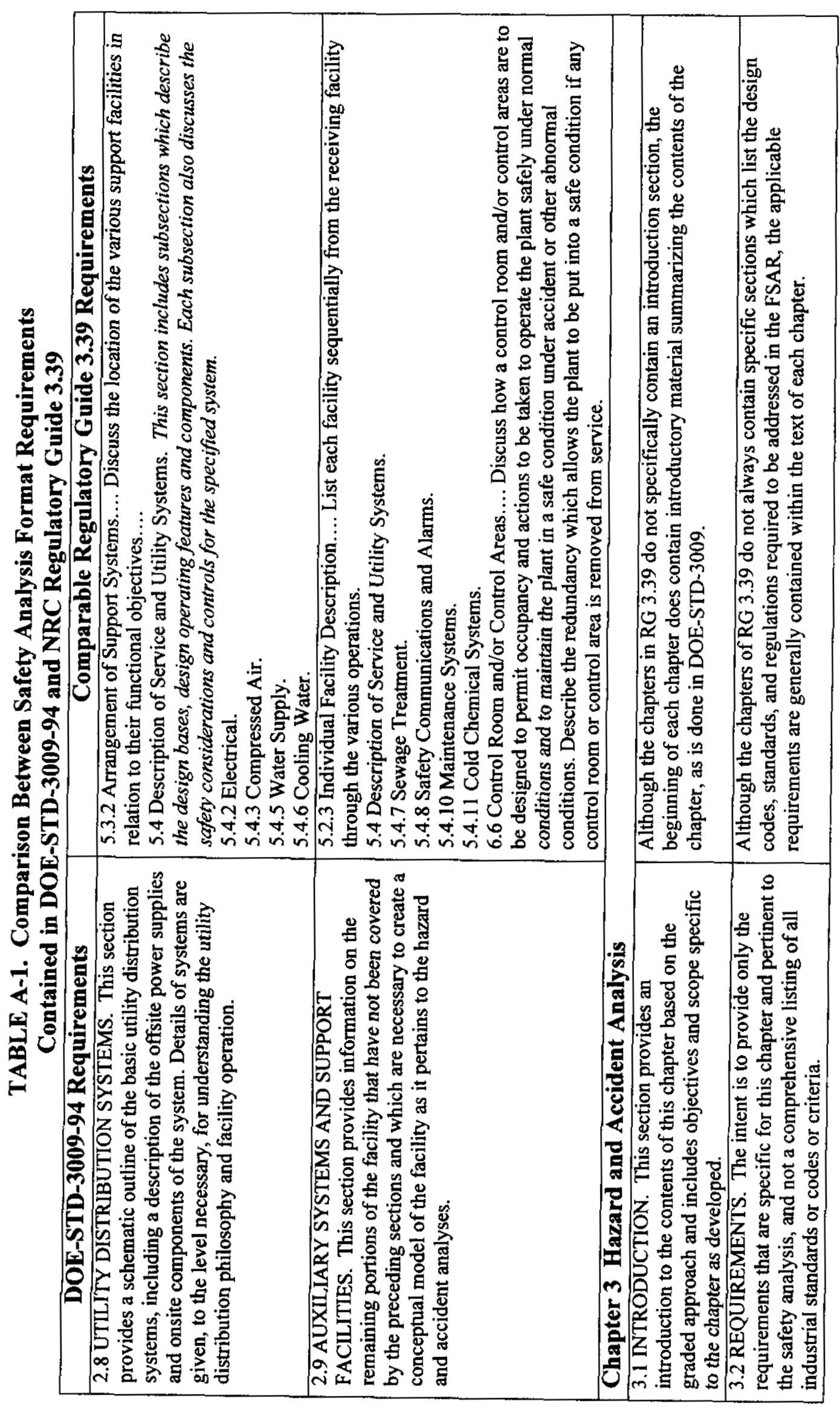


HNF-6533 Rev. 0

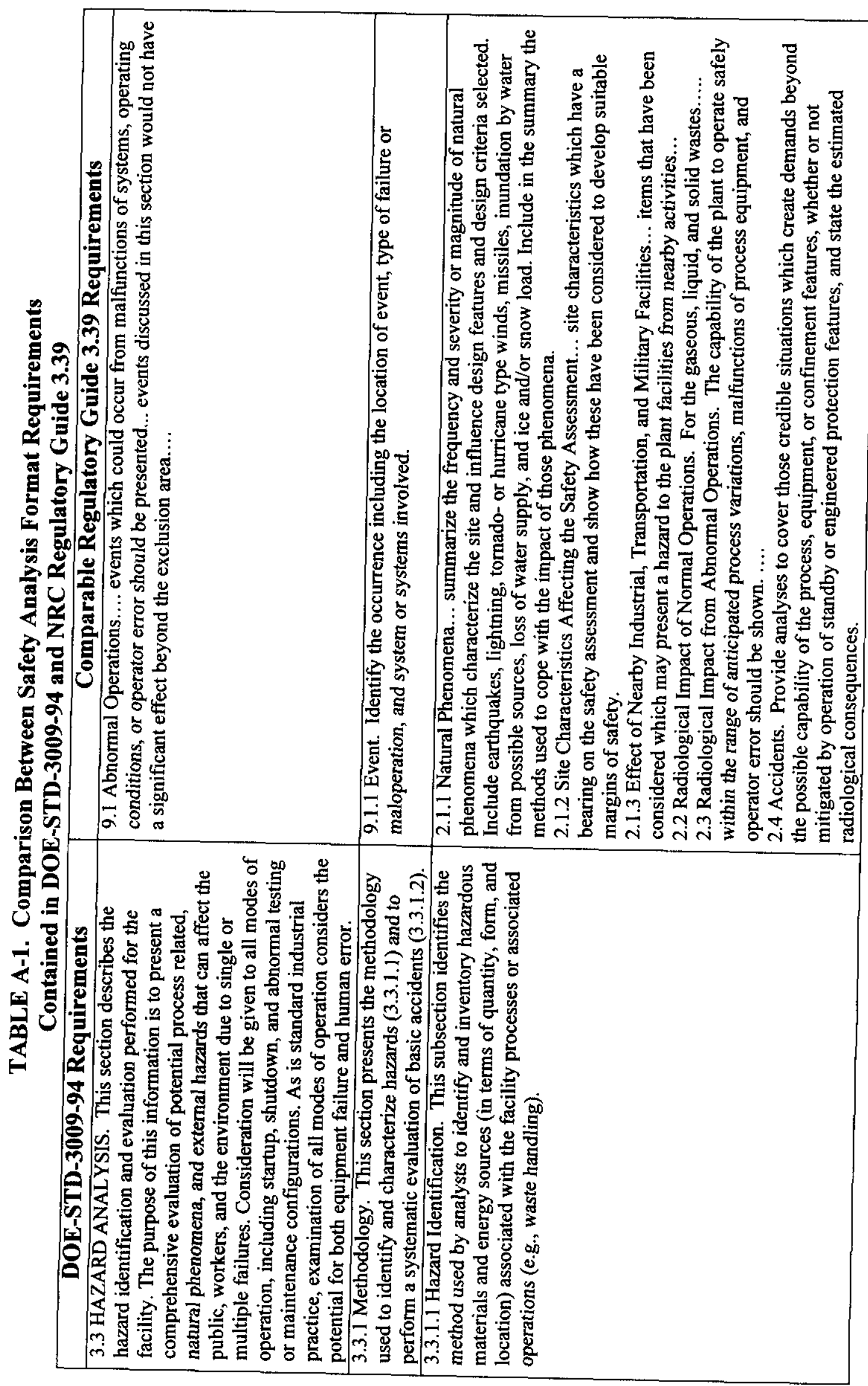




\section{HNF-6533 Rev. 0}

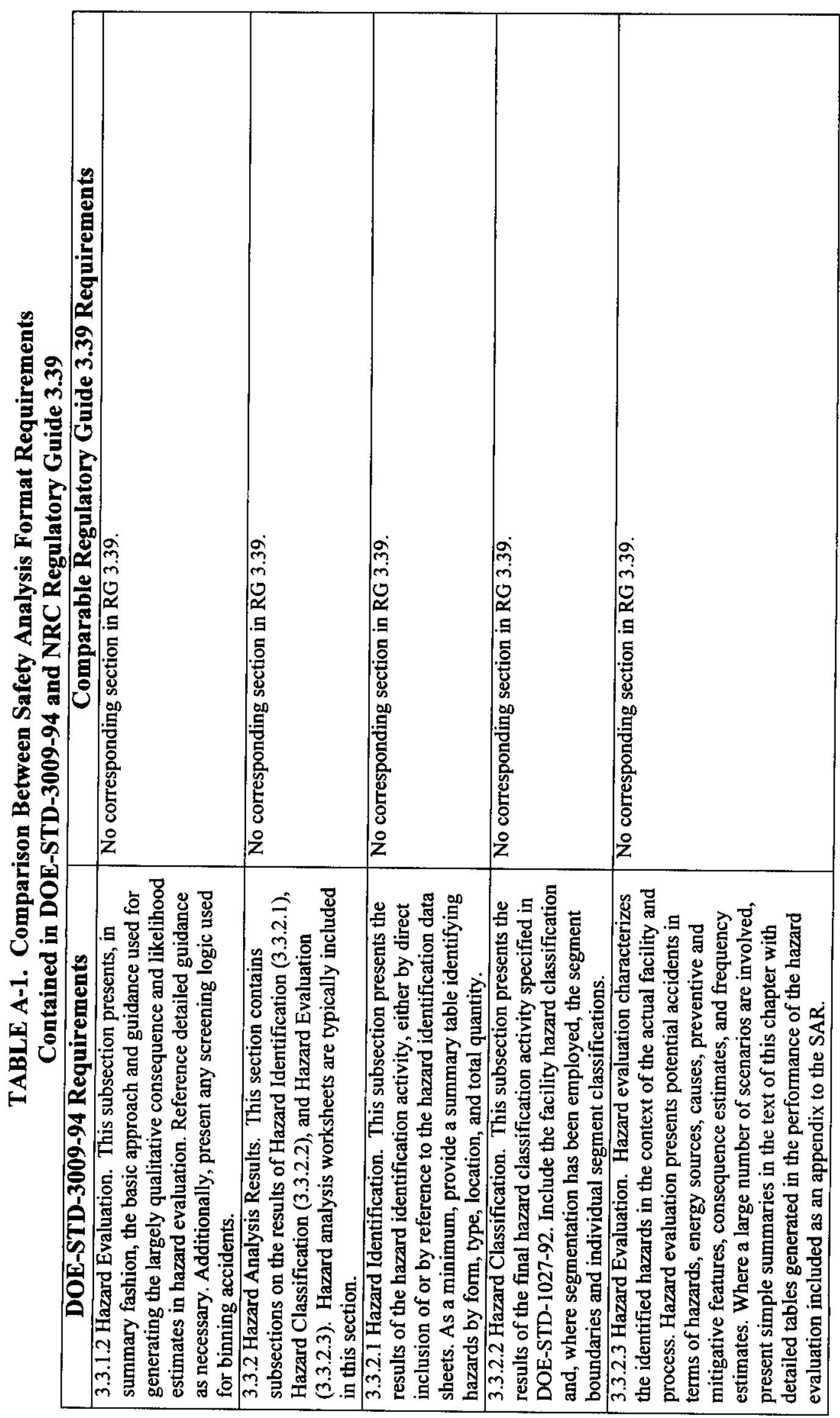


HNF-6533 Rev. 0

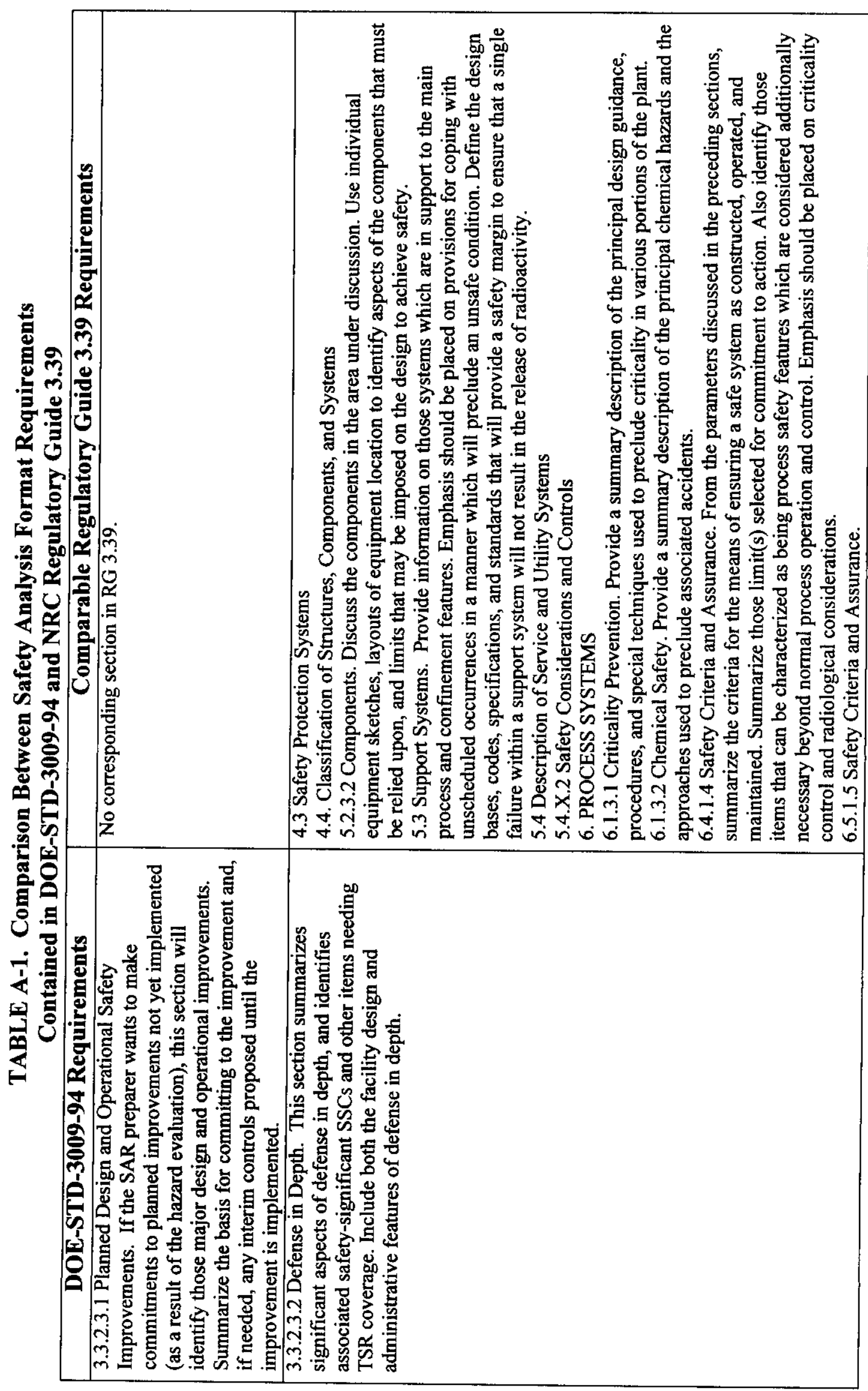


HNF-6533 Rev. 0

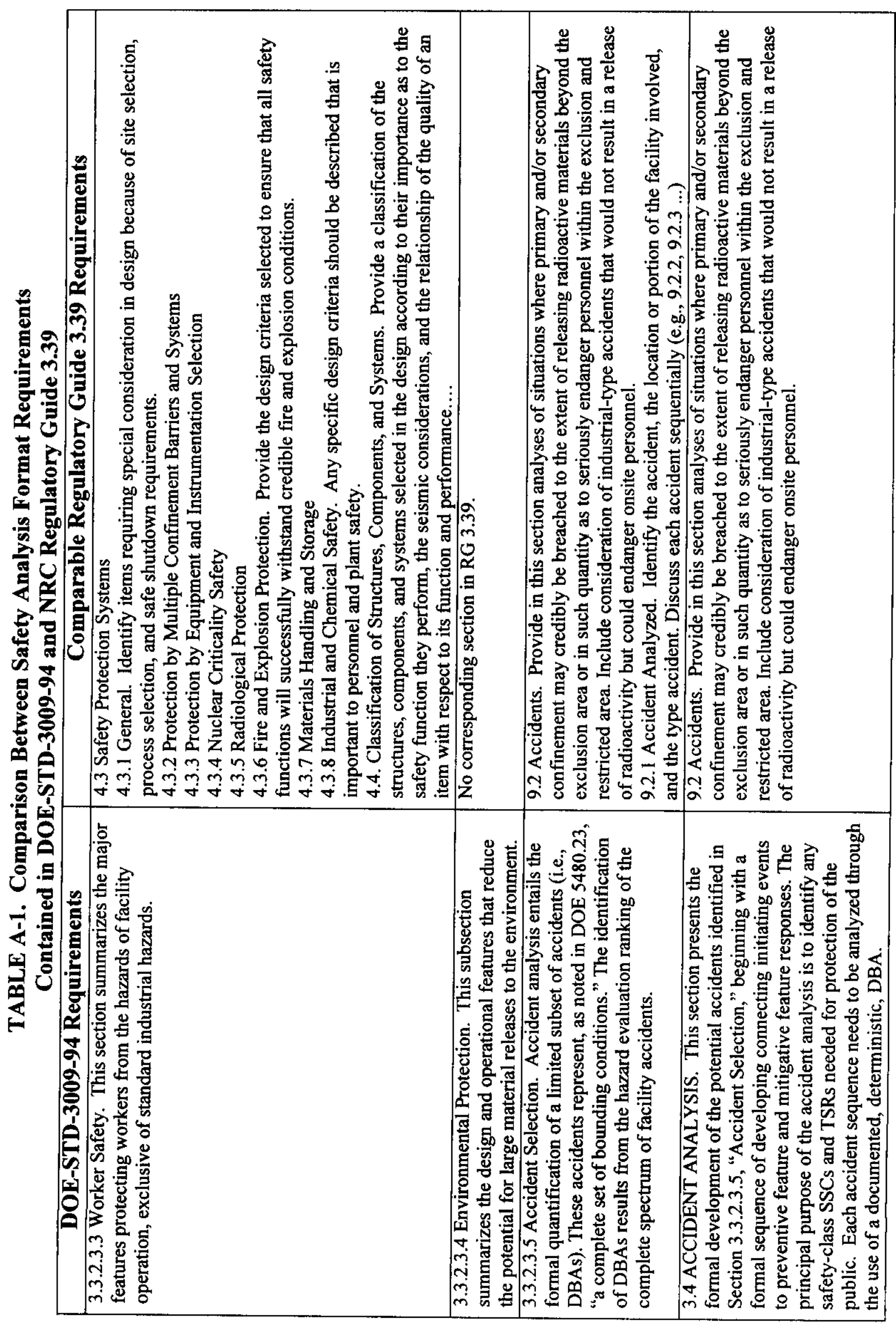


HNF-6533 Rev. 0

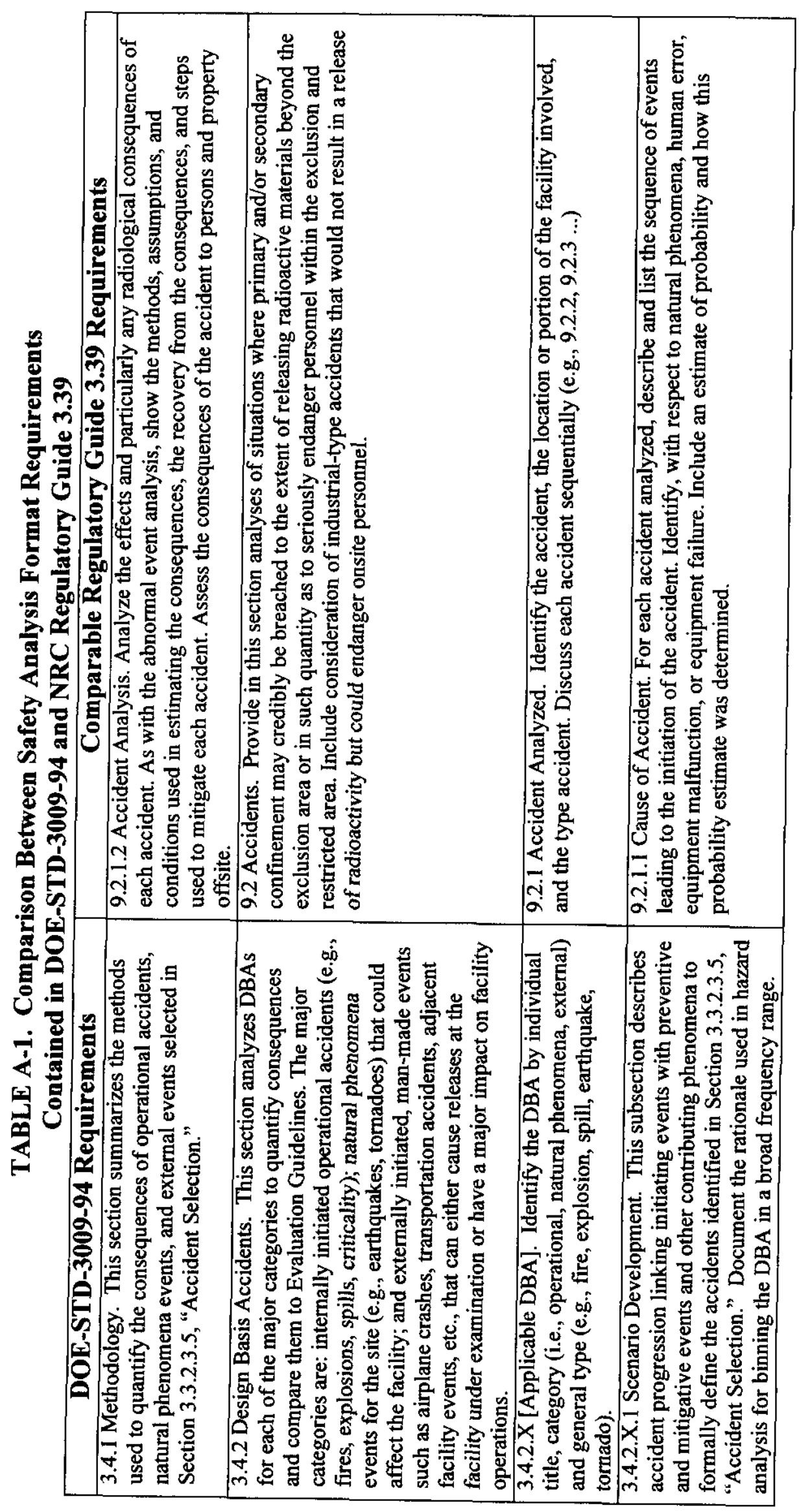


HNF-6533 Rev. 0

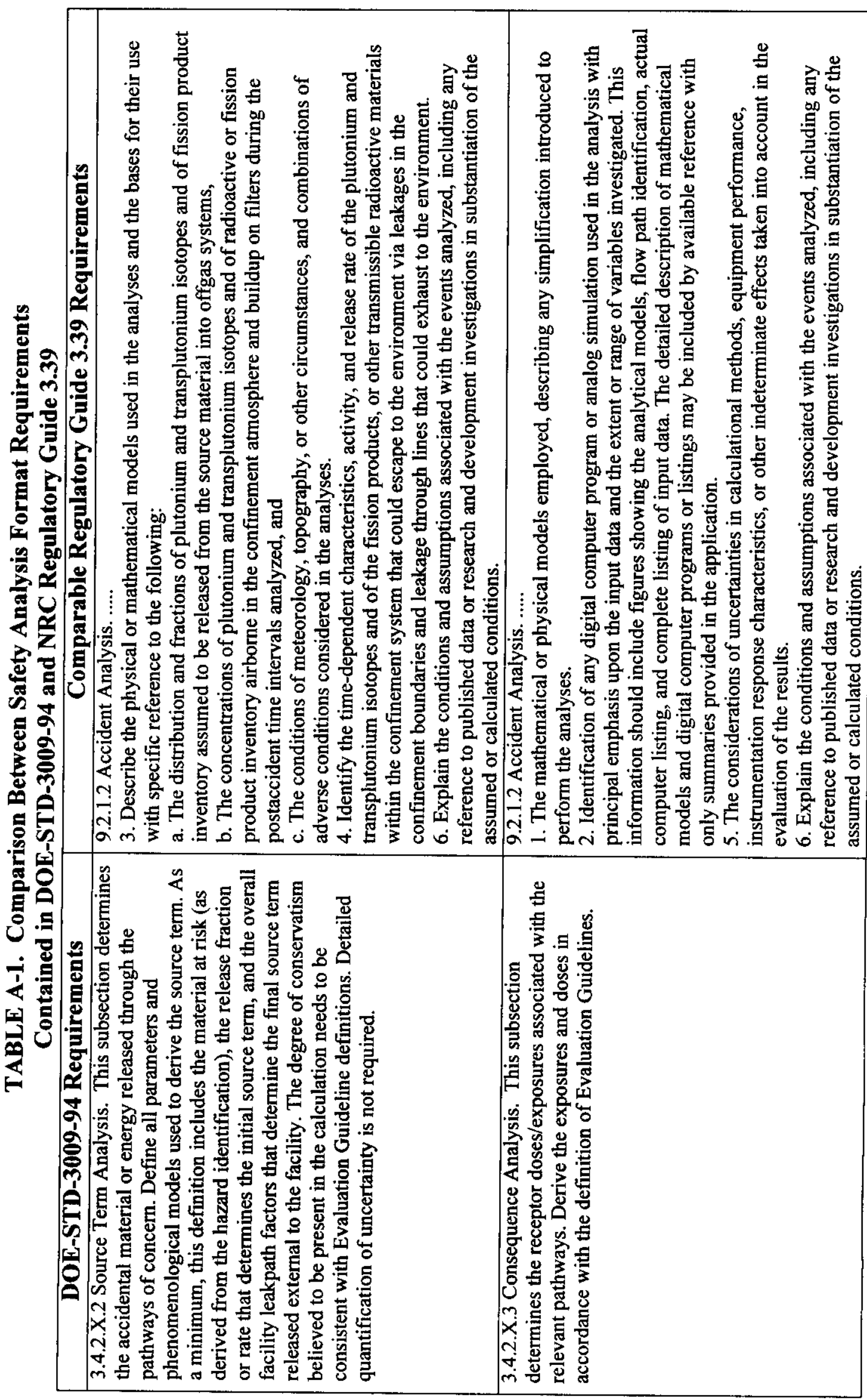


HNF-6533 Rev. 0

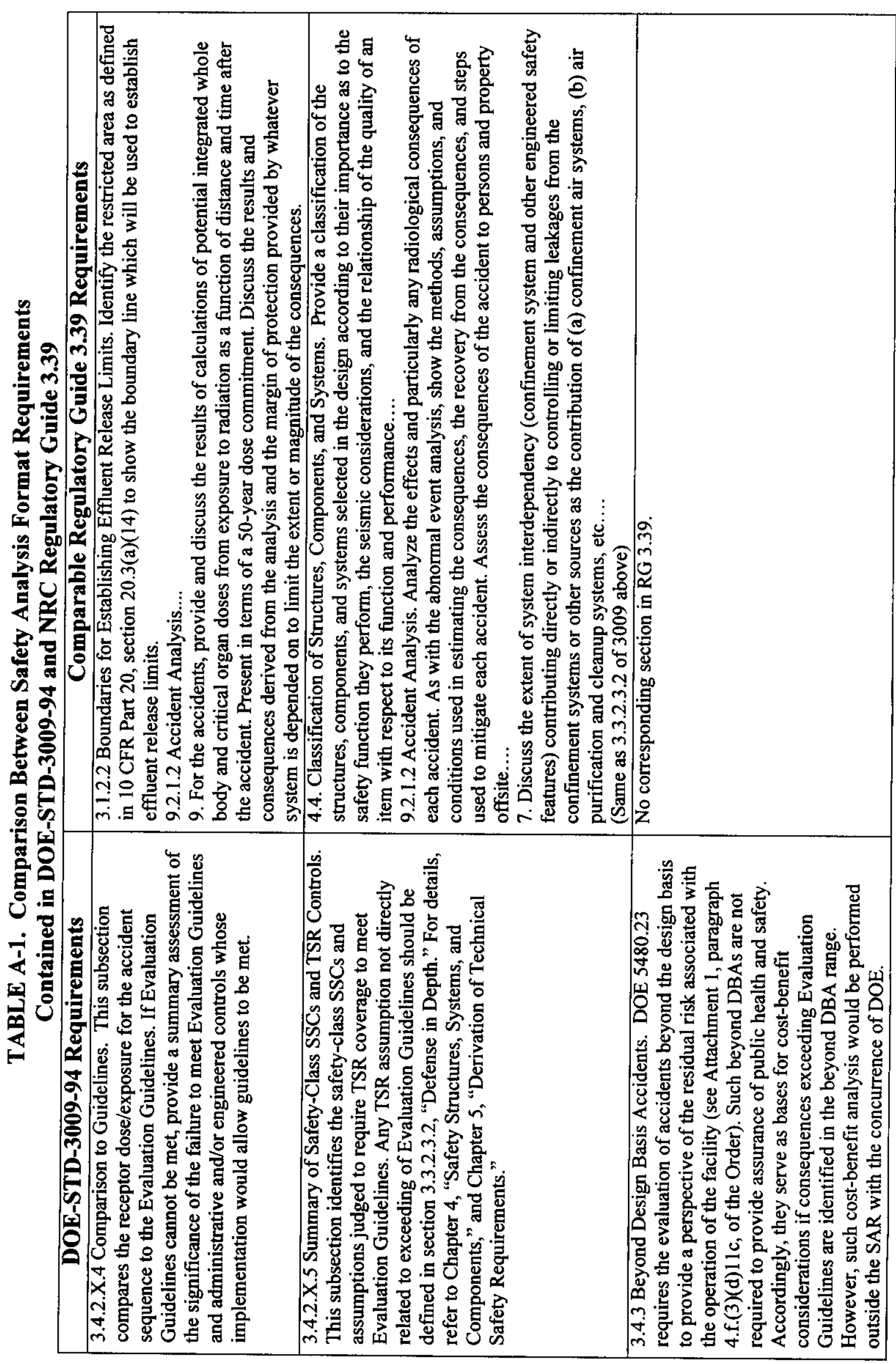


HNF-6533 Rev. 0

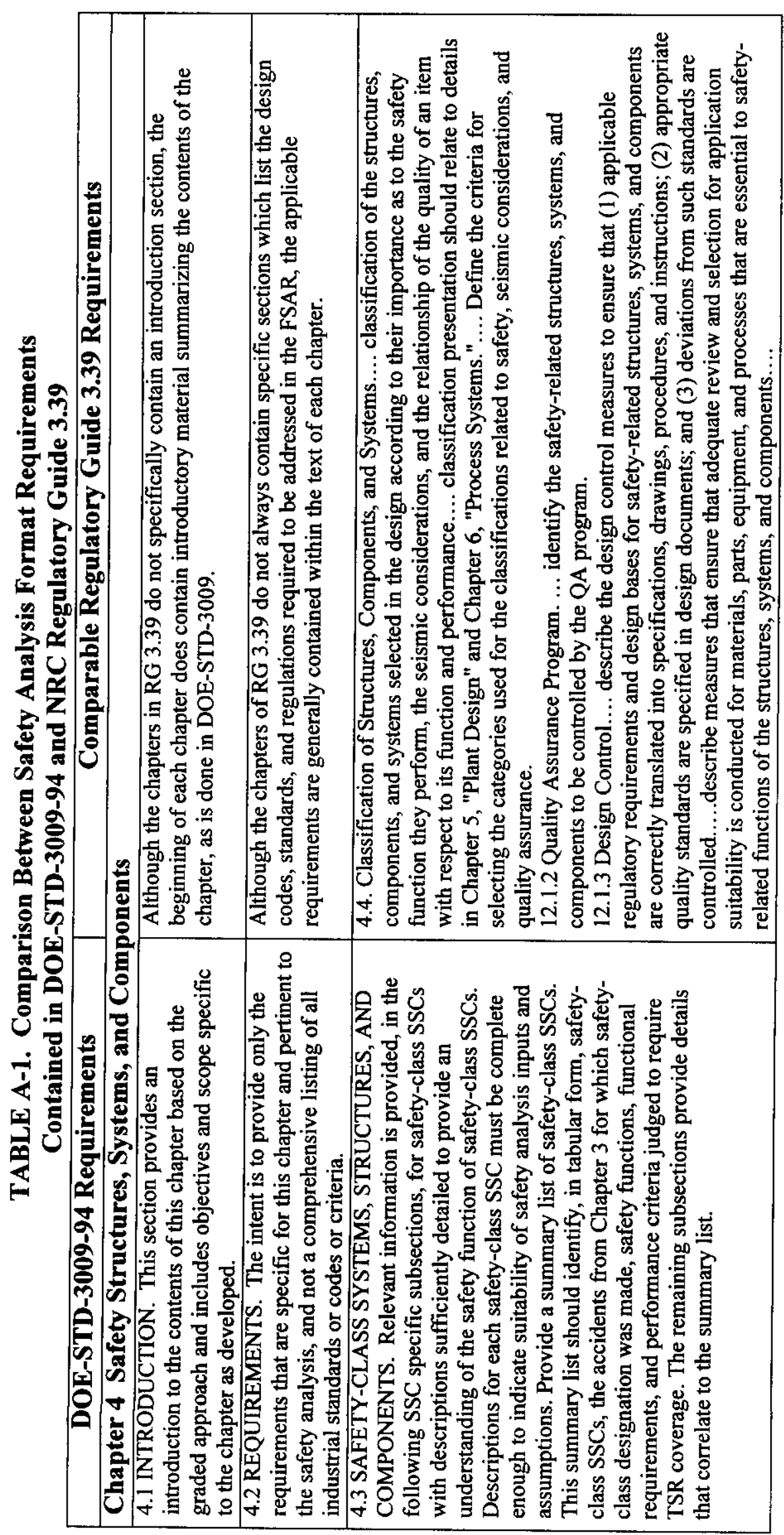


HNF-6533 Rev. 0

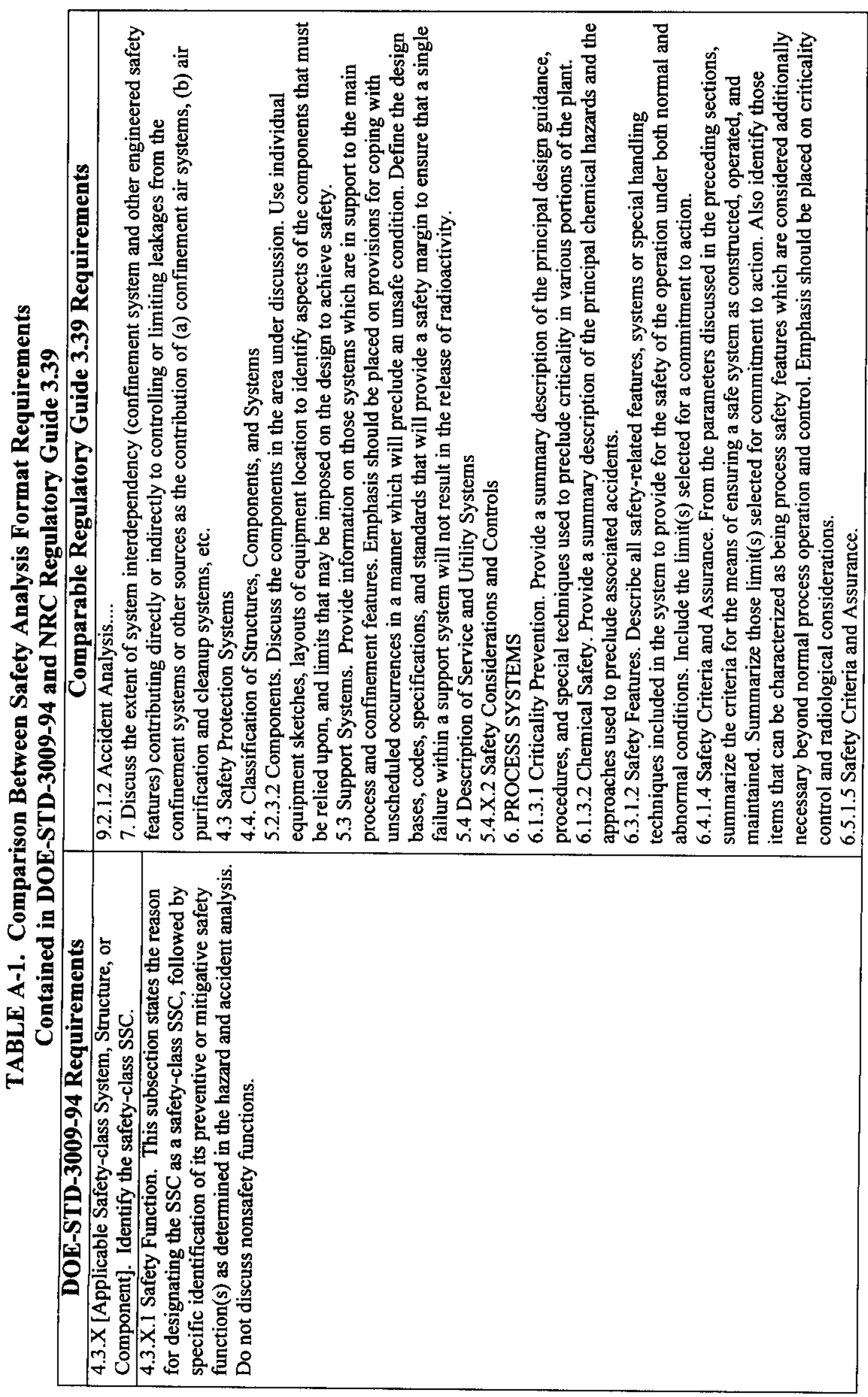


HNF-6533 Rev. 0

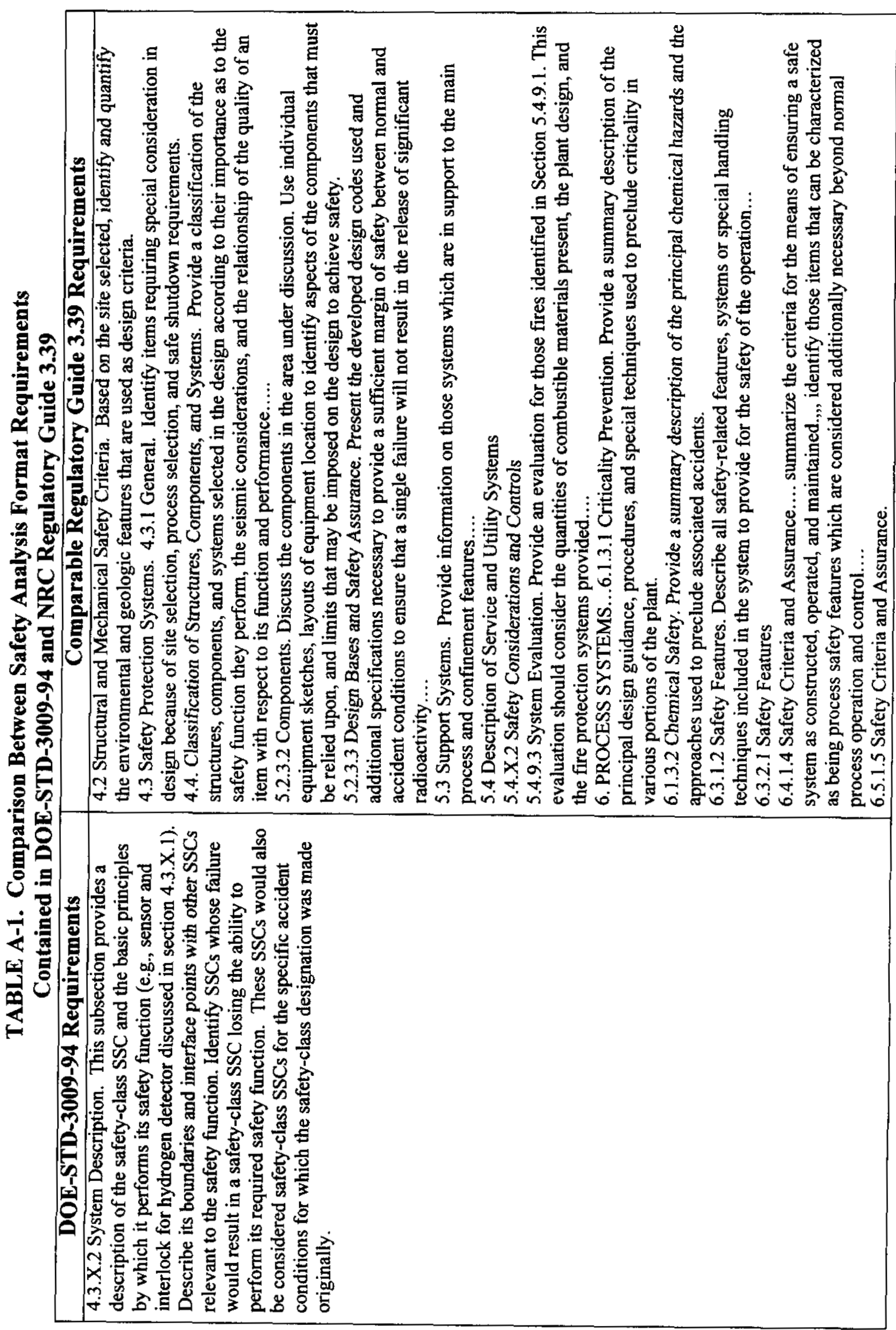


HNF-6533 Rev. 0

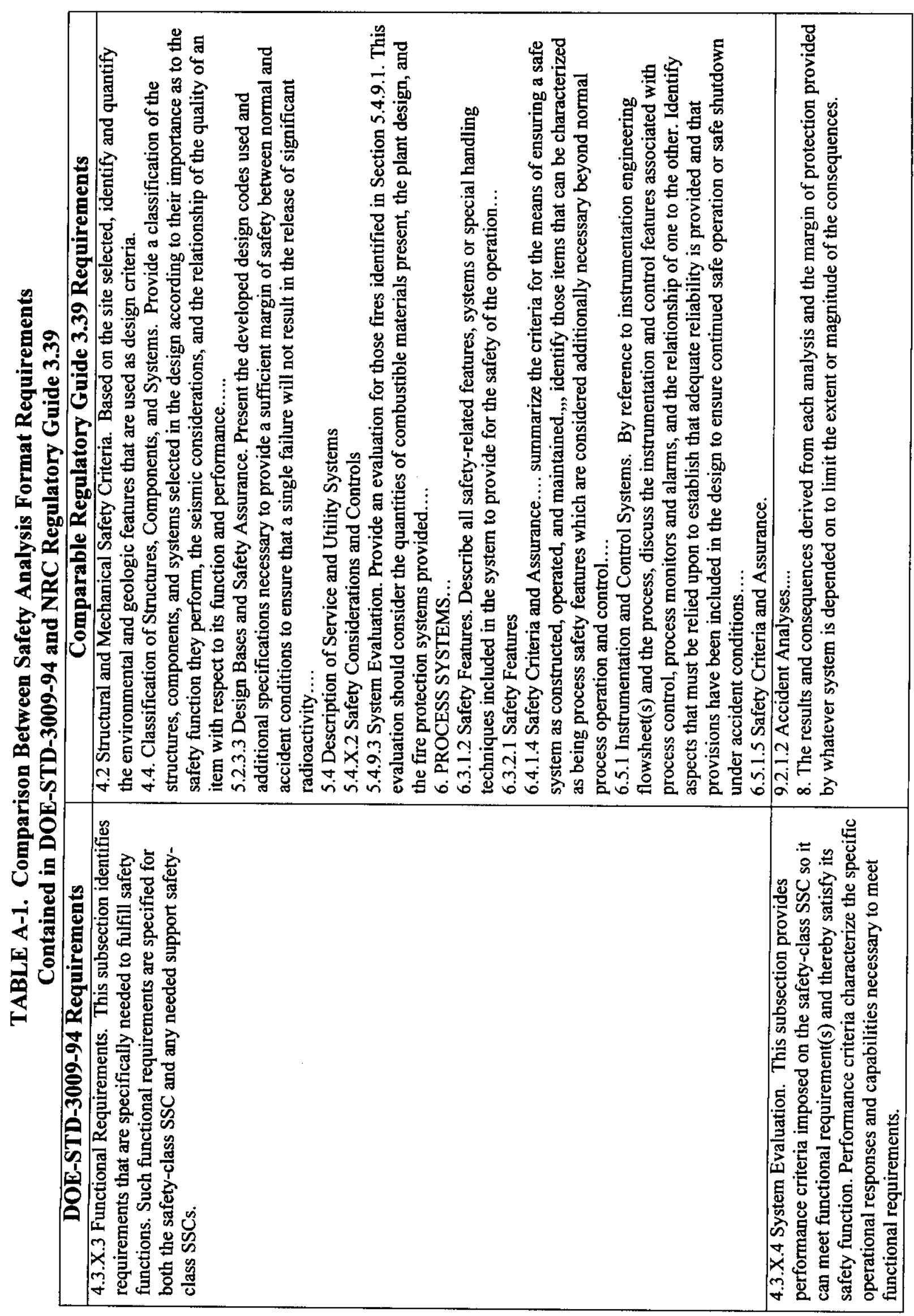


HNF-6533 Rev. 0

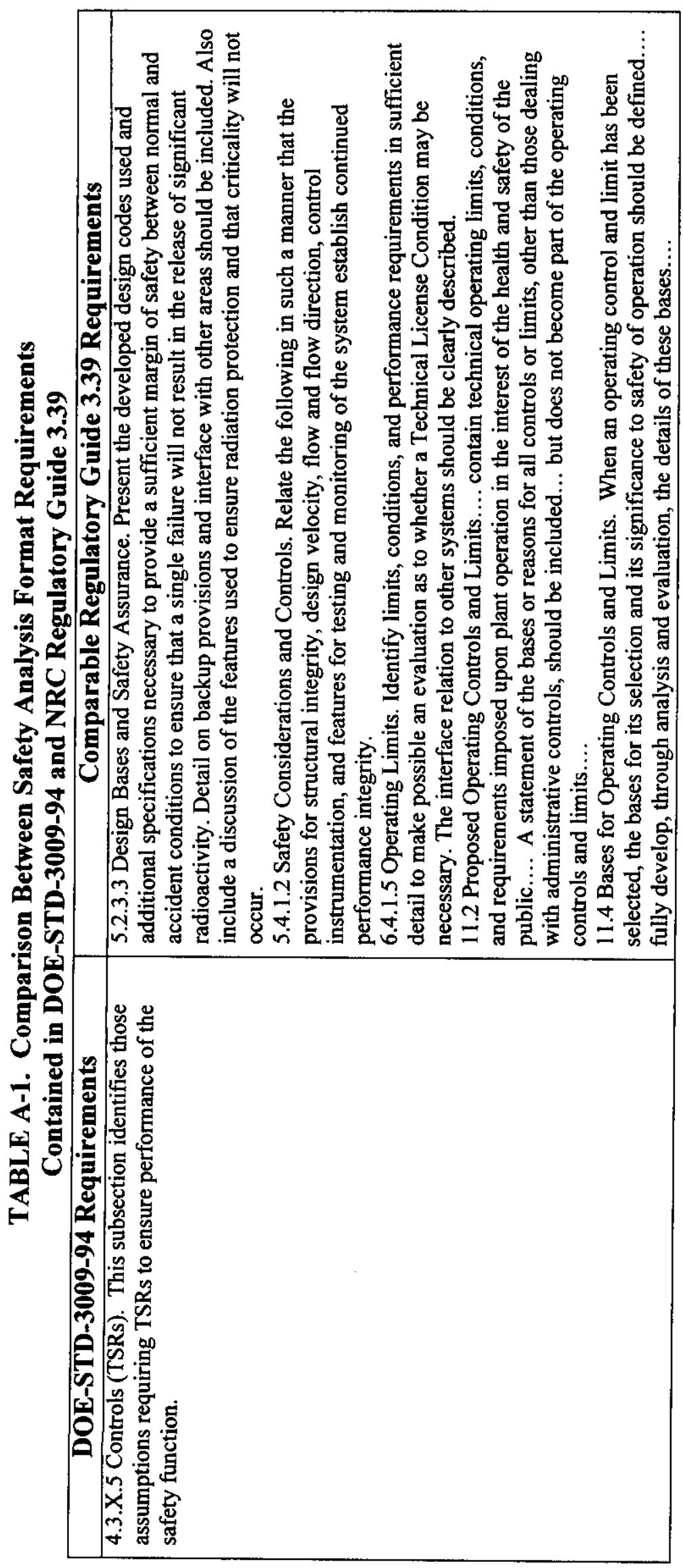


HNF-6533 Rev. 0

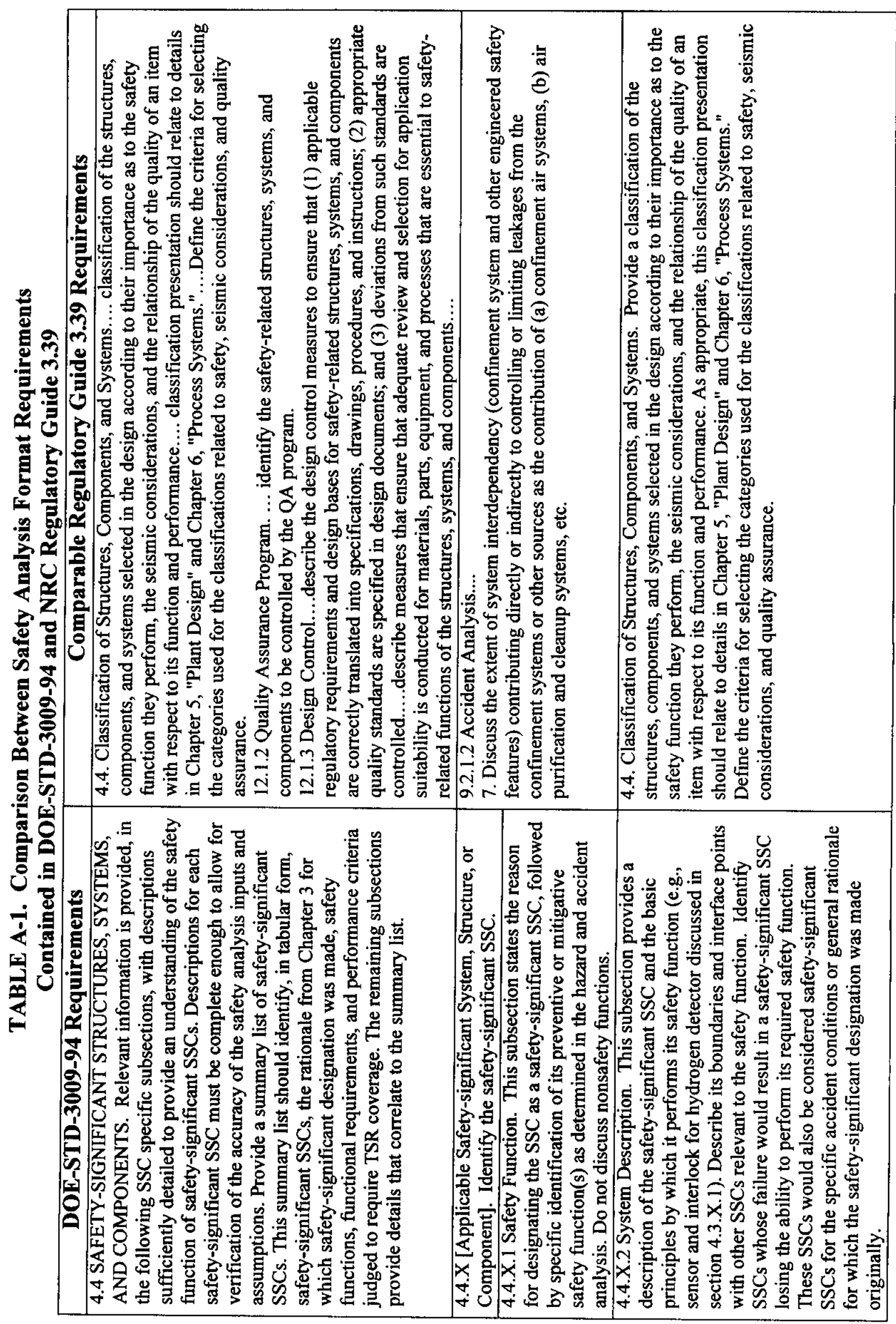


HNF-6533 Rev. 0

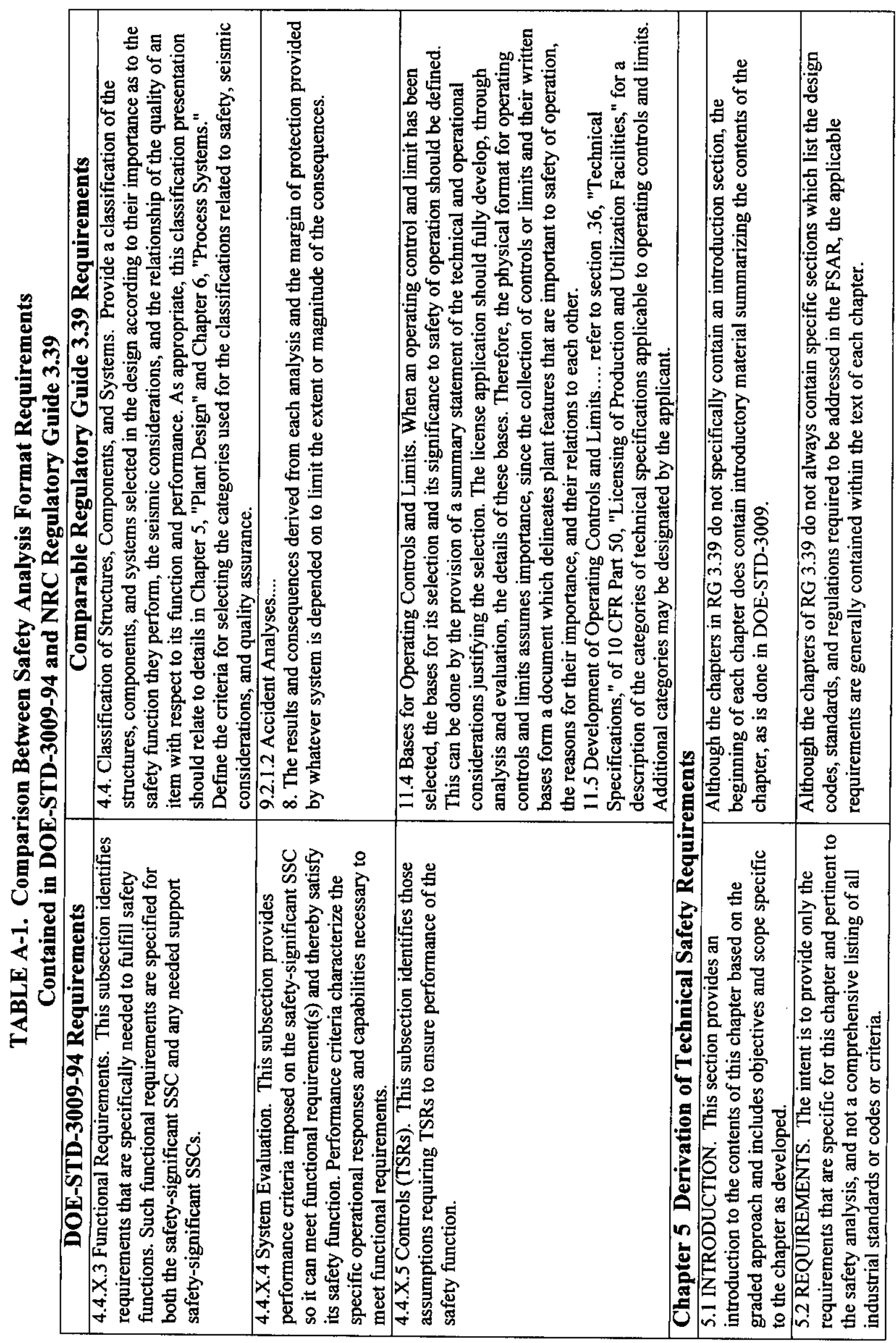


HNF-6533 Rev. 0

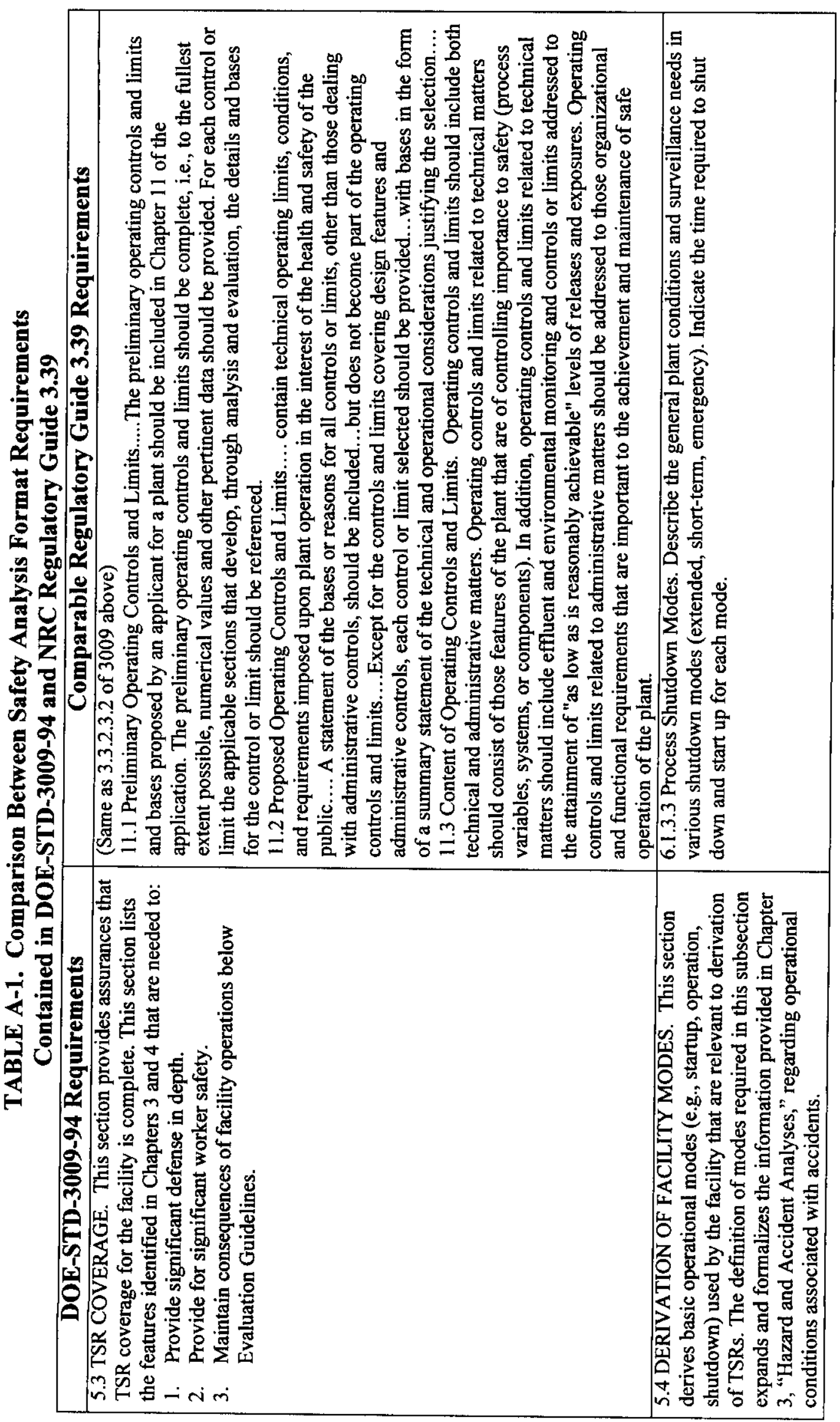


HNF-6533 Rev. 0

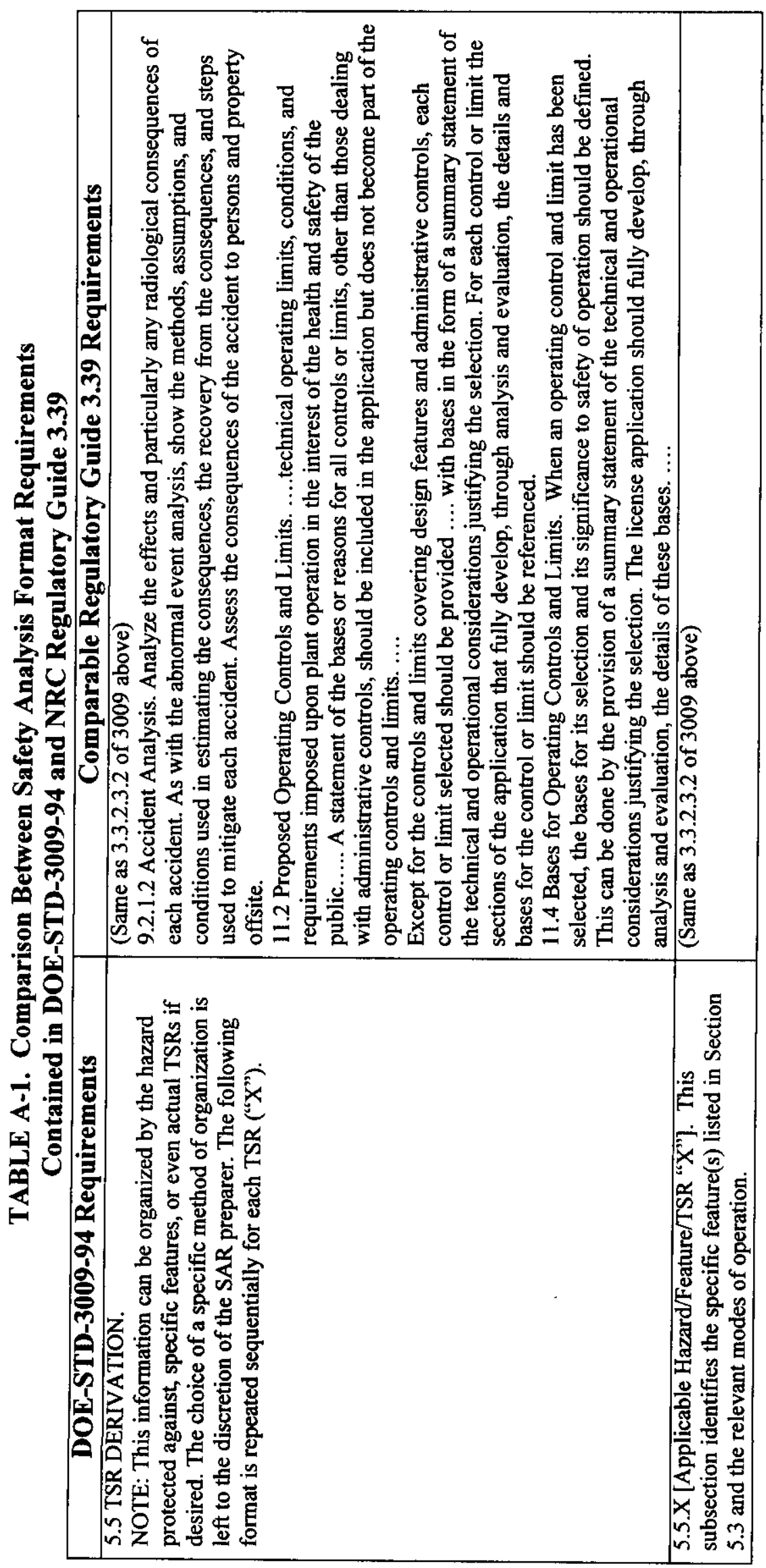


HNF-6533 Rev. 0

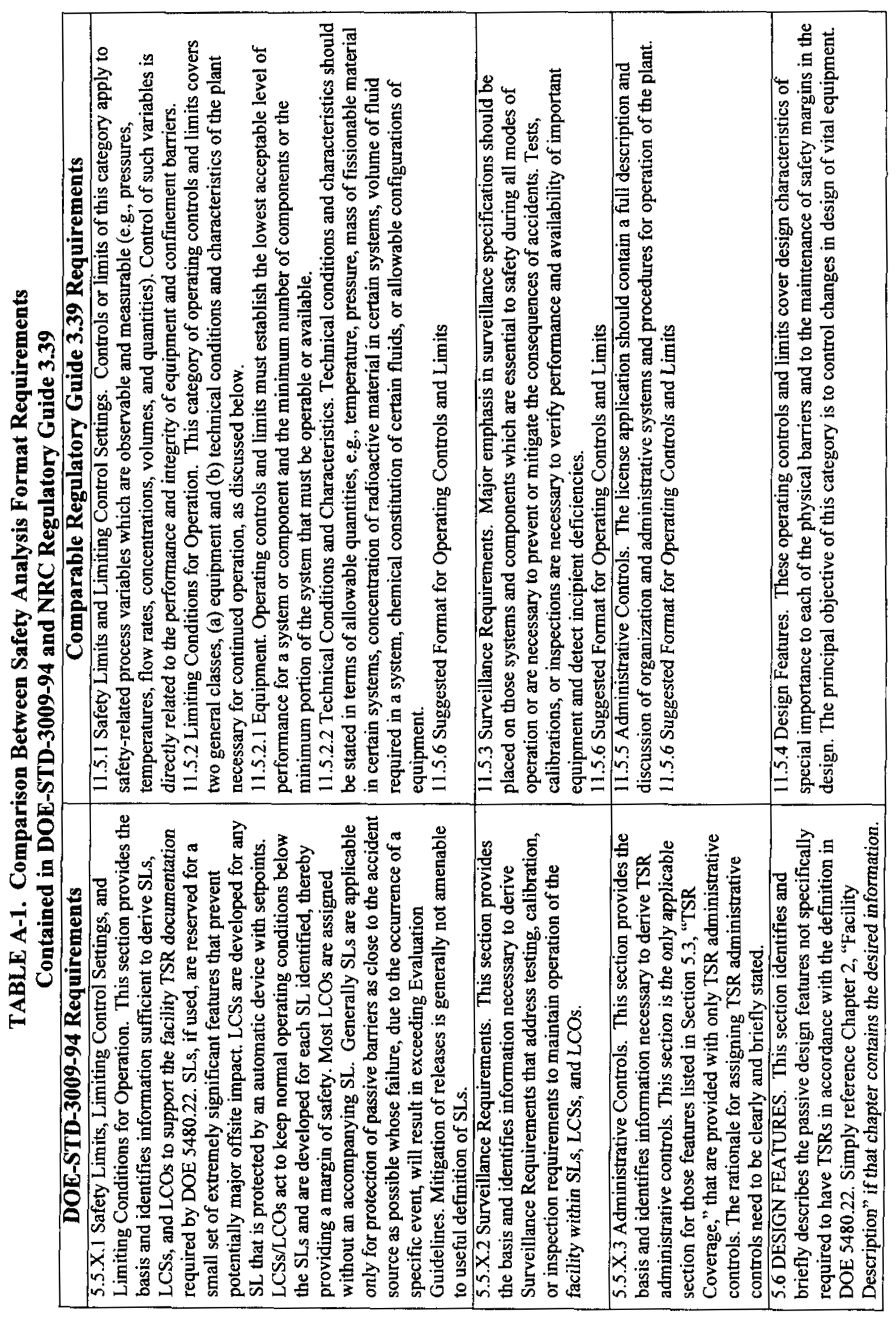


HNF-6533 Rev. 0

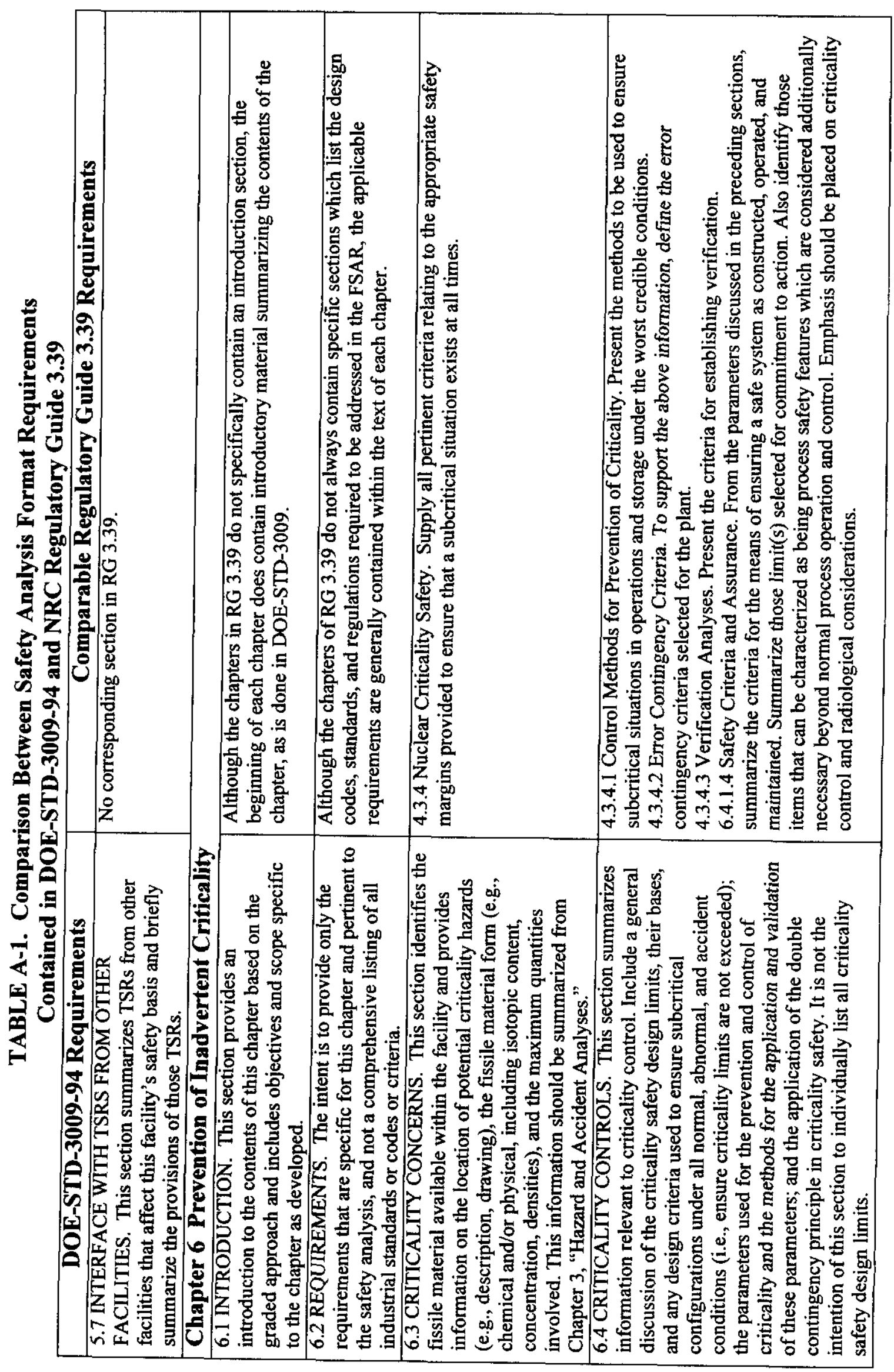


HNF-6533 Rev. 0

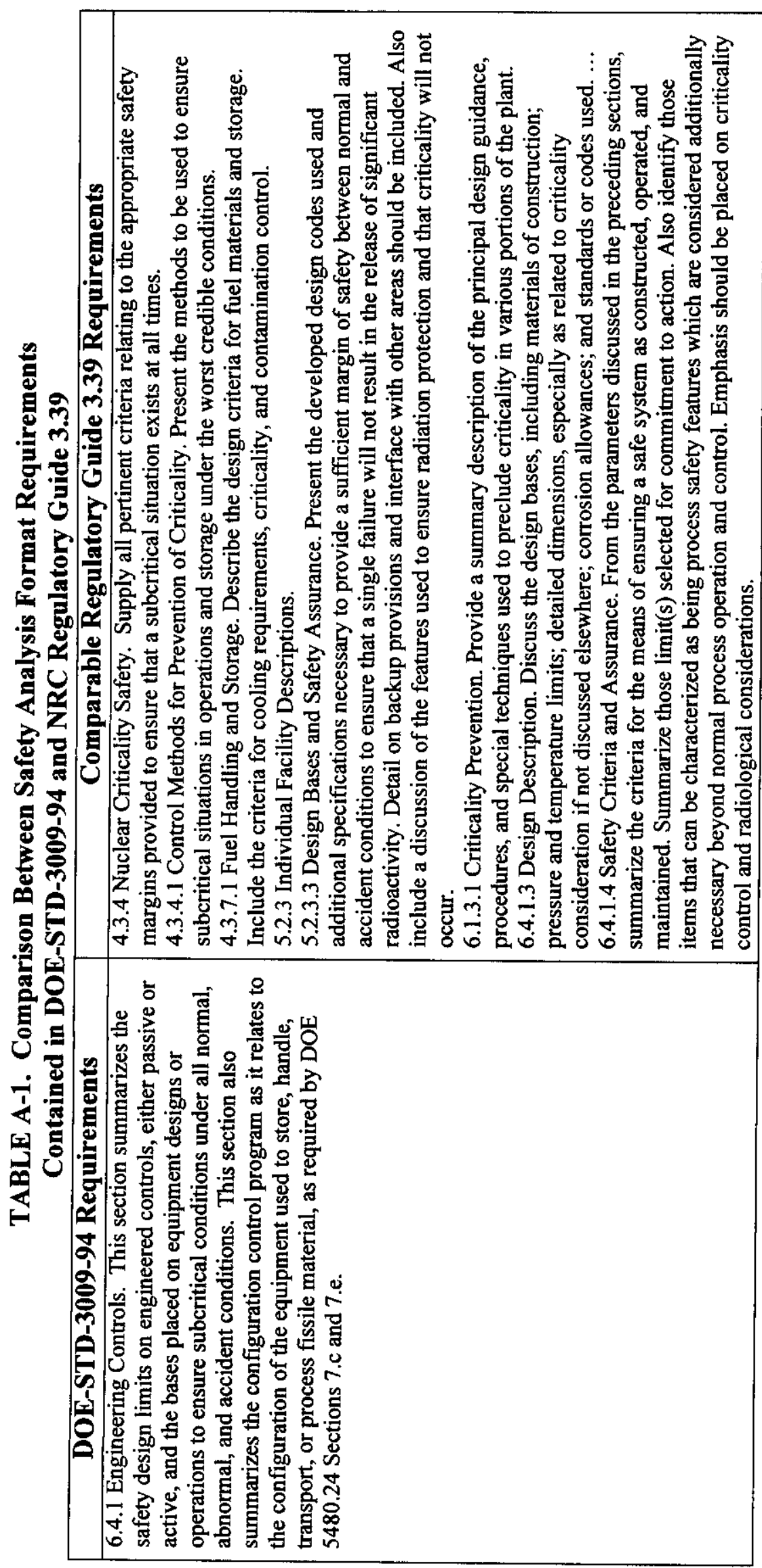




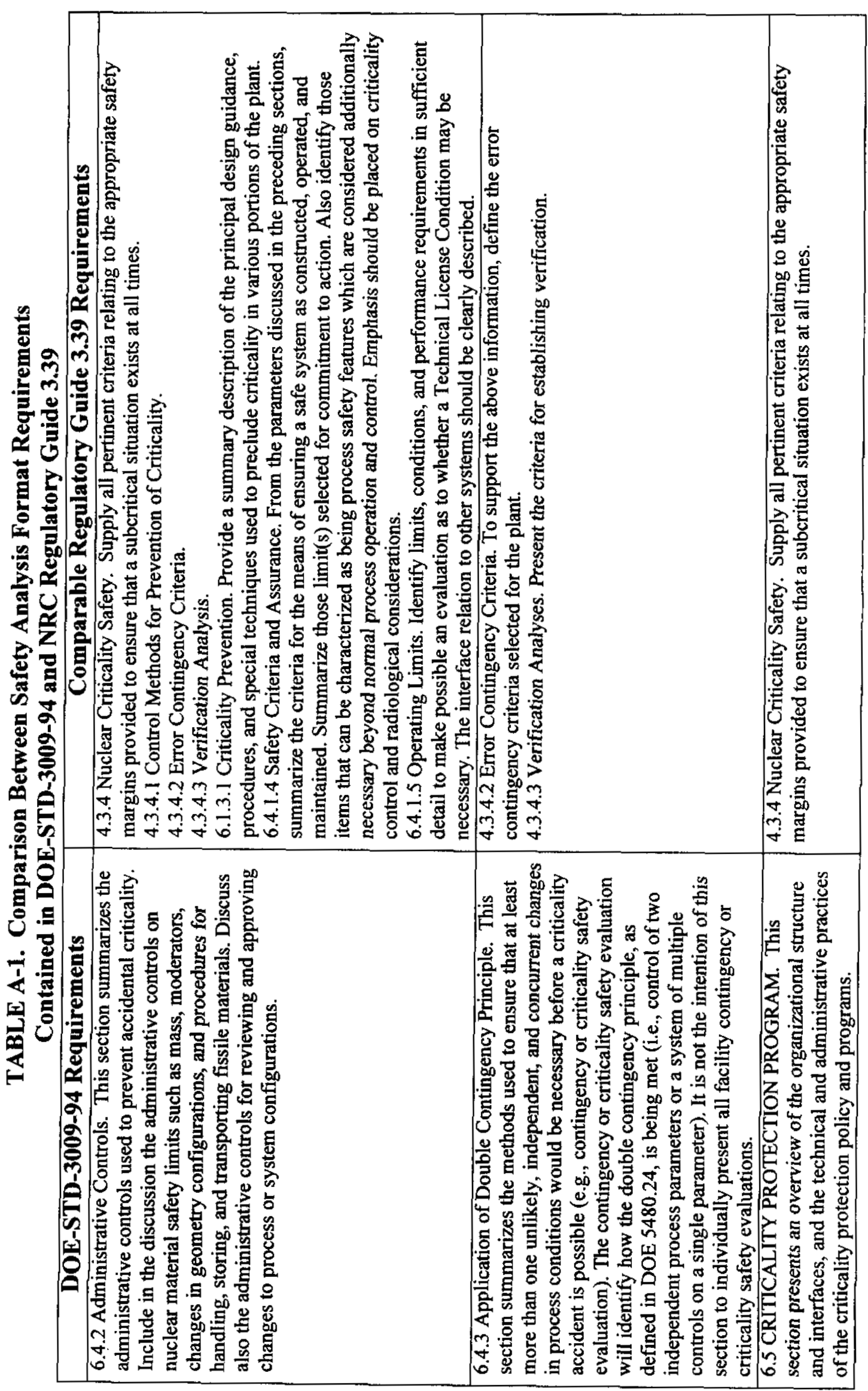


HNF-6533 Rev. 0

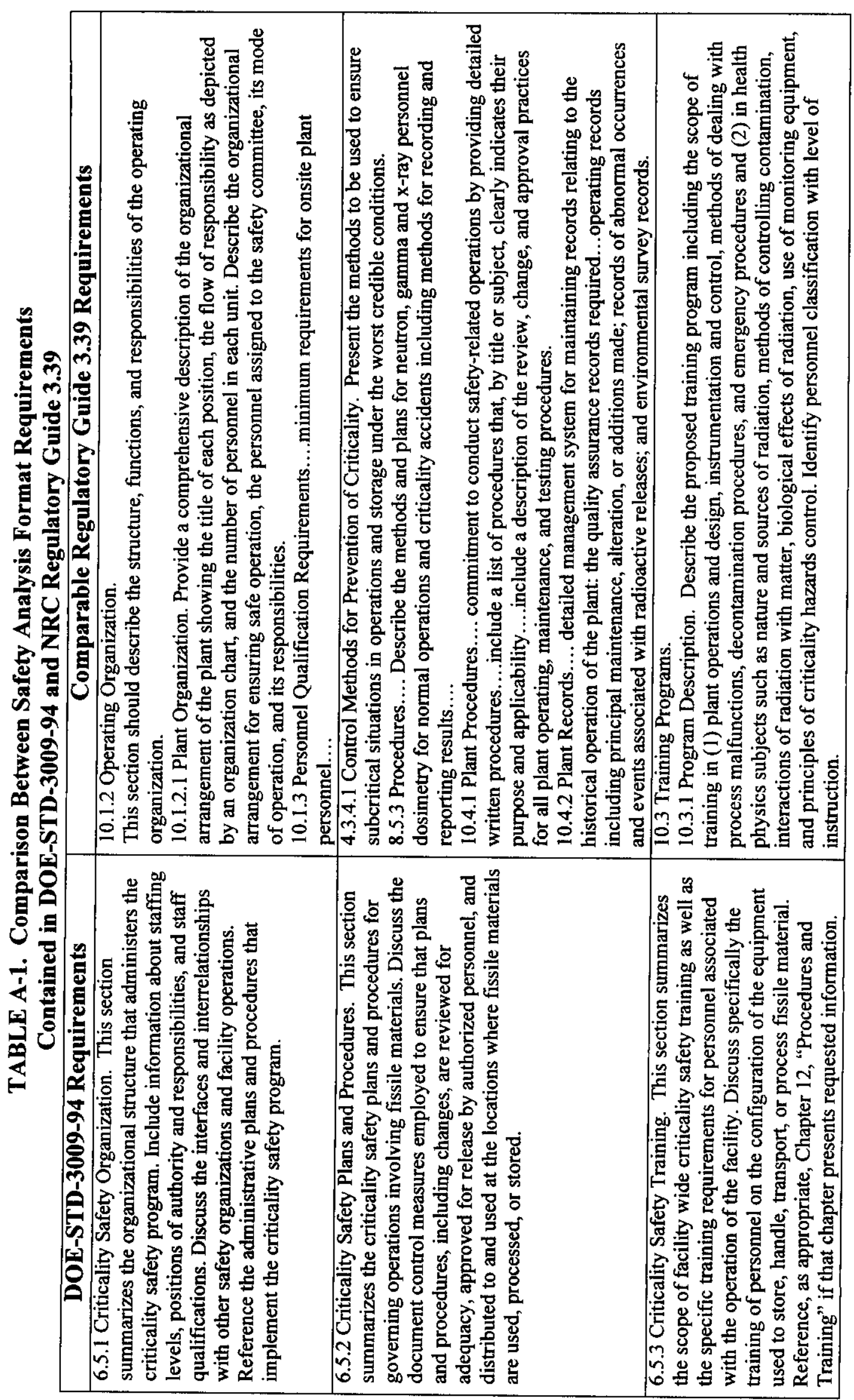


HNF-6533 Rev. 0

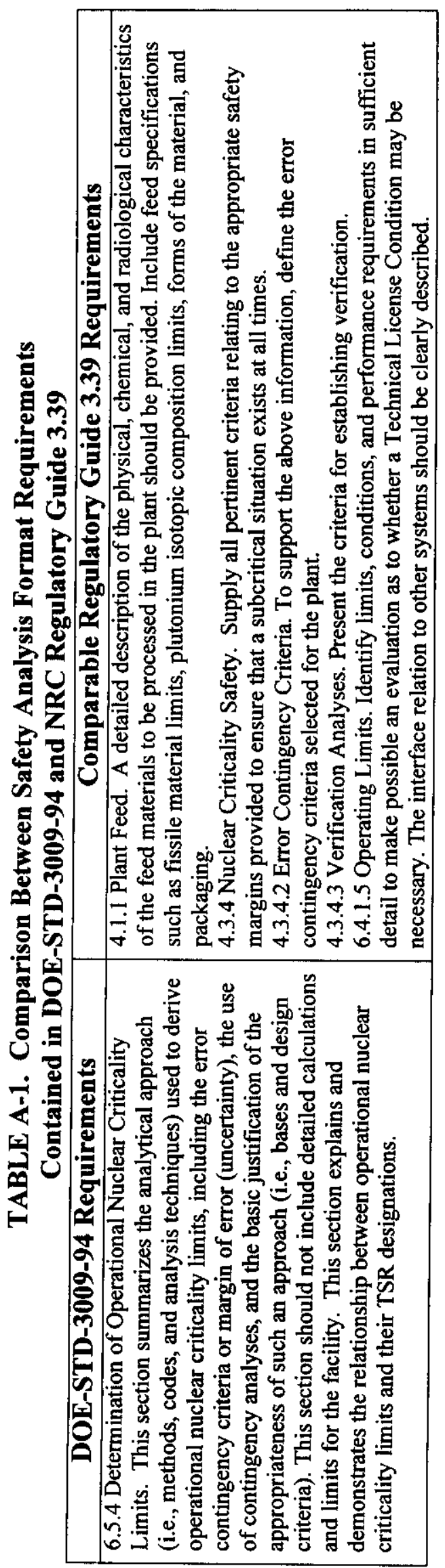


HNF-6533 Rev. 0

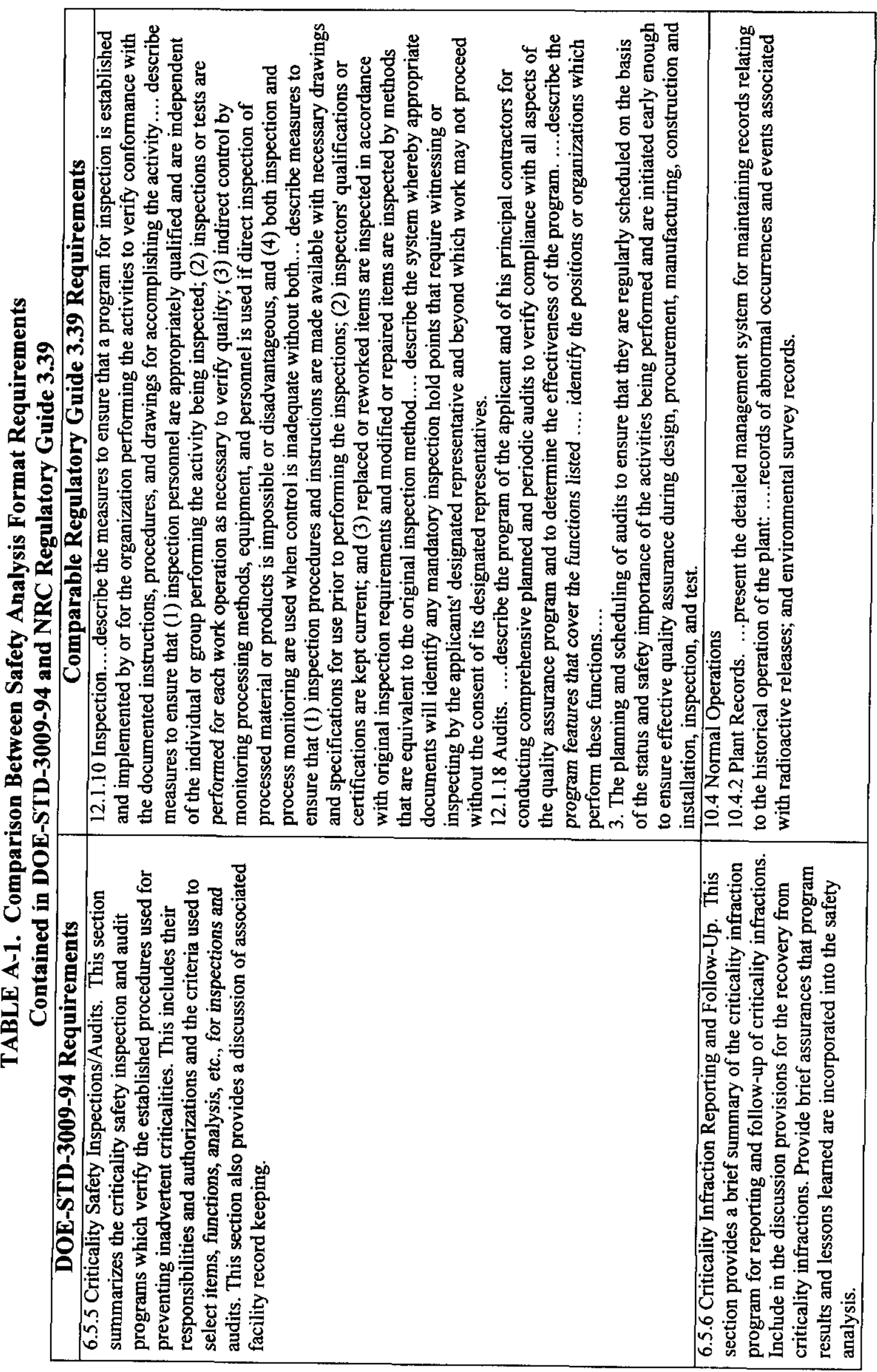


HNF-6533 Rev. 0

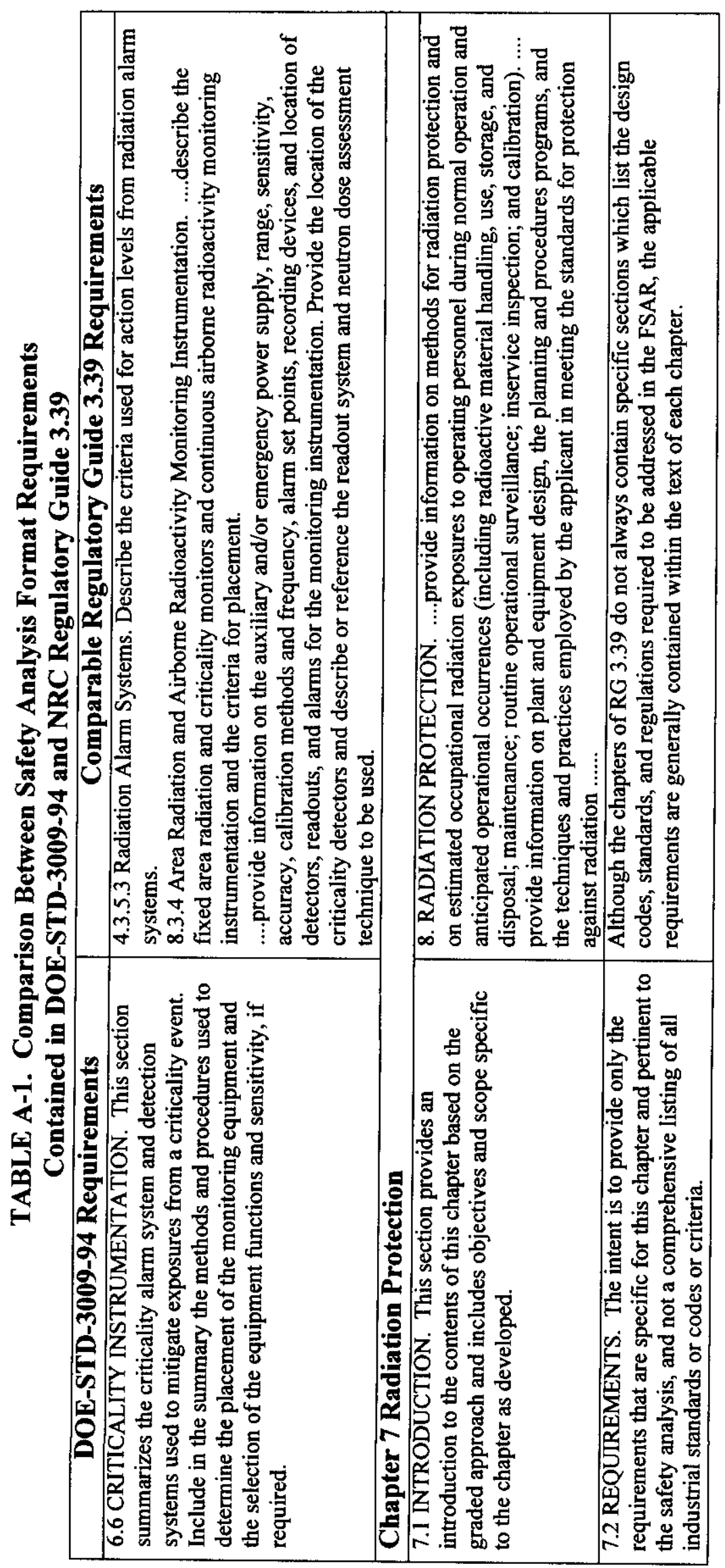


HNF-6533 Rev. 0

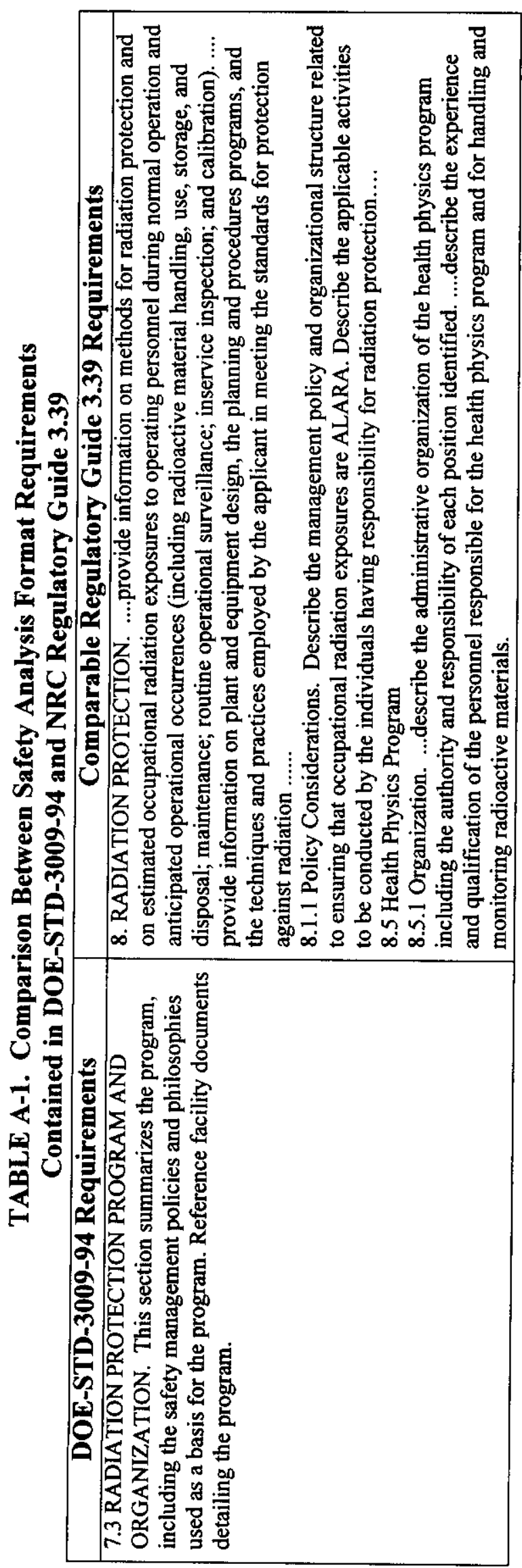




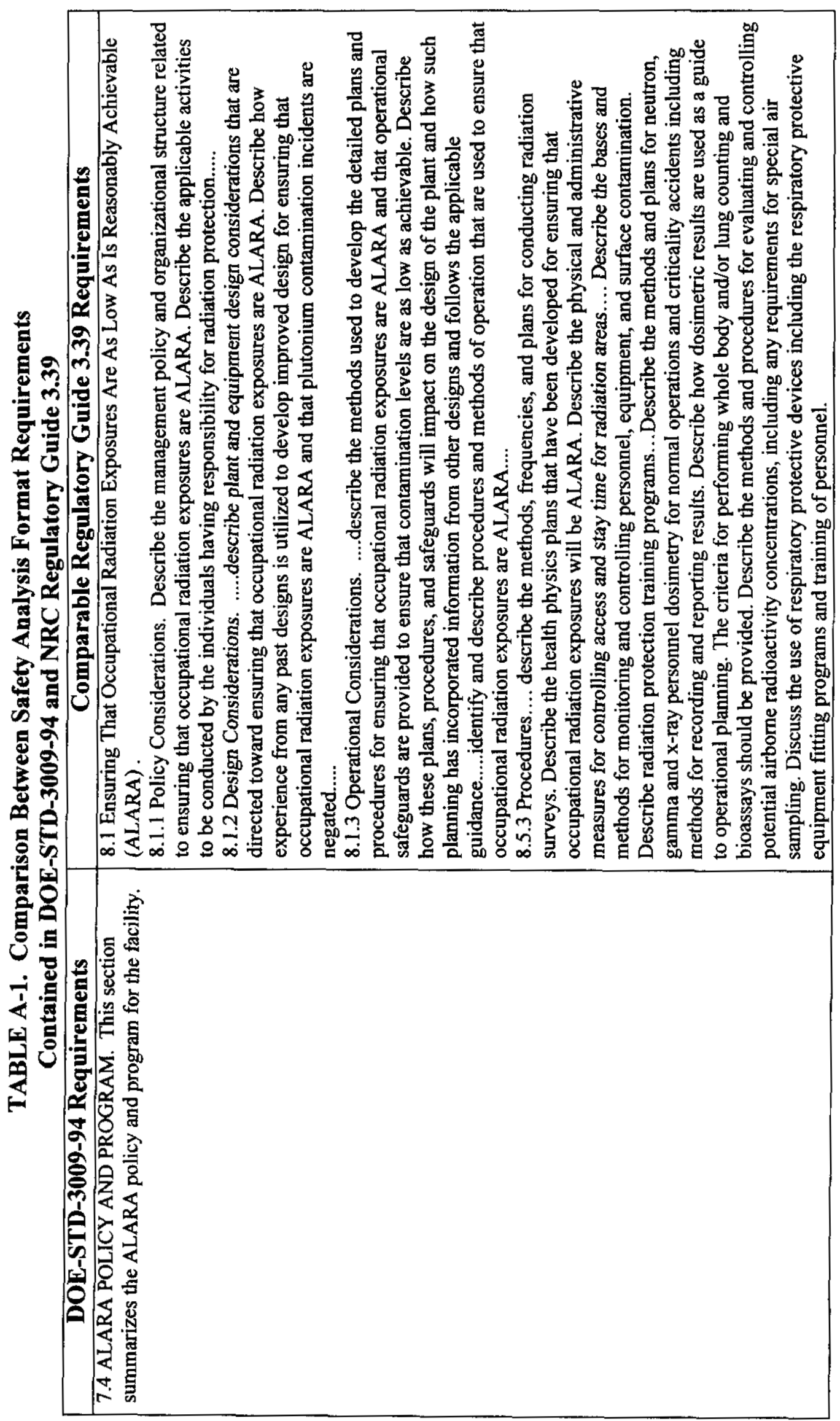


HNF-6533 Rev. 0

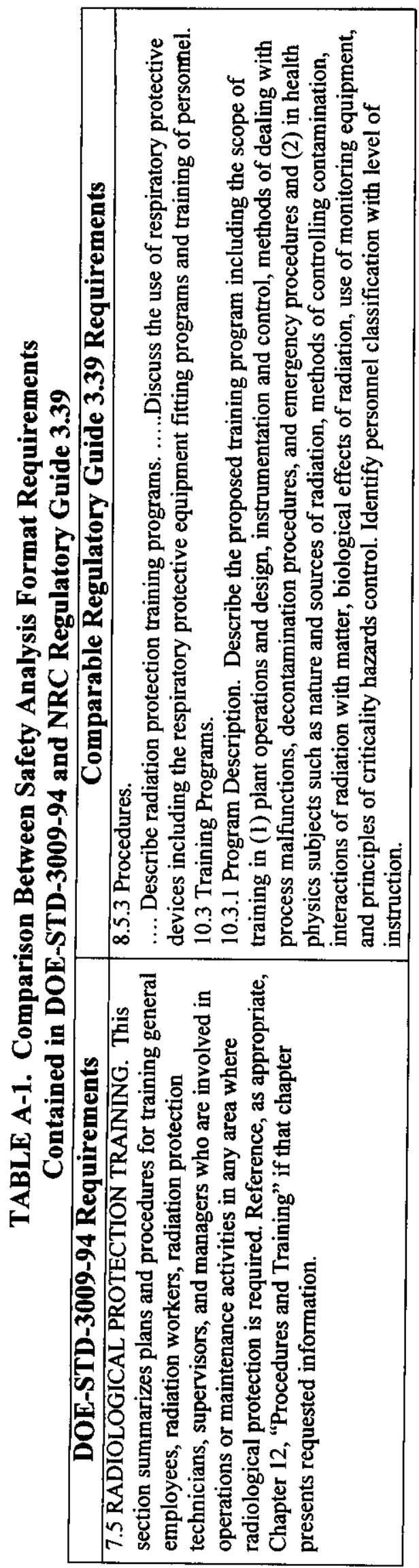


HNF-6533 Rev. 0

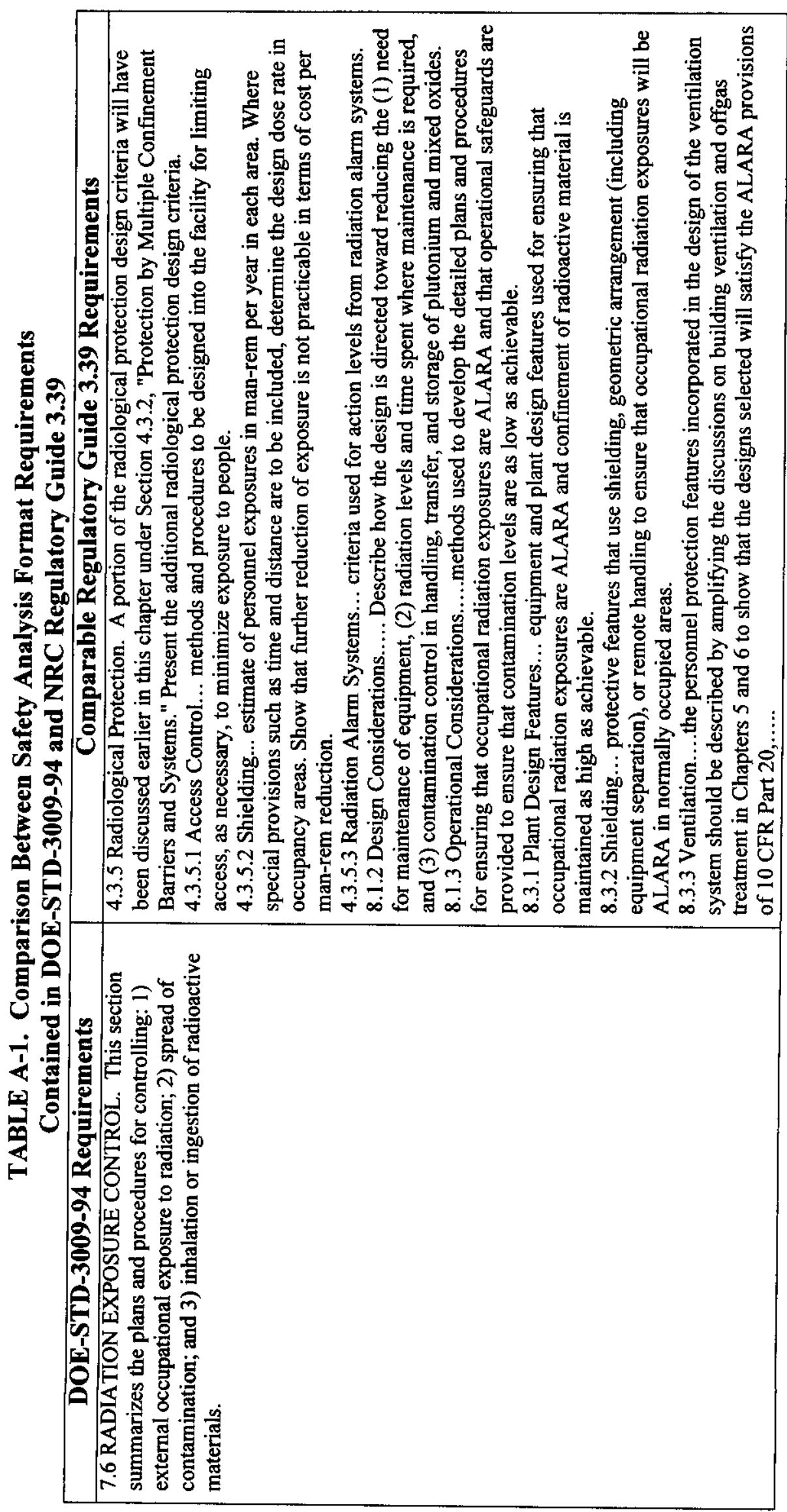


HNF-6533 Rev. 0

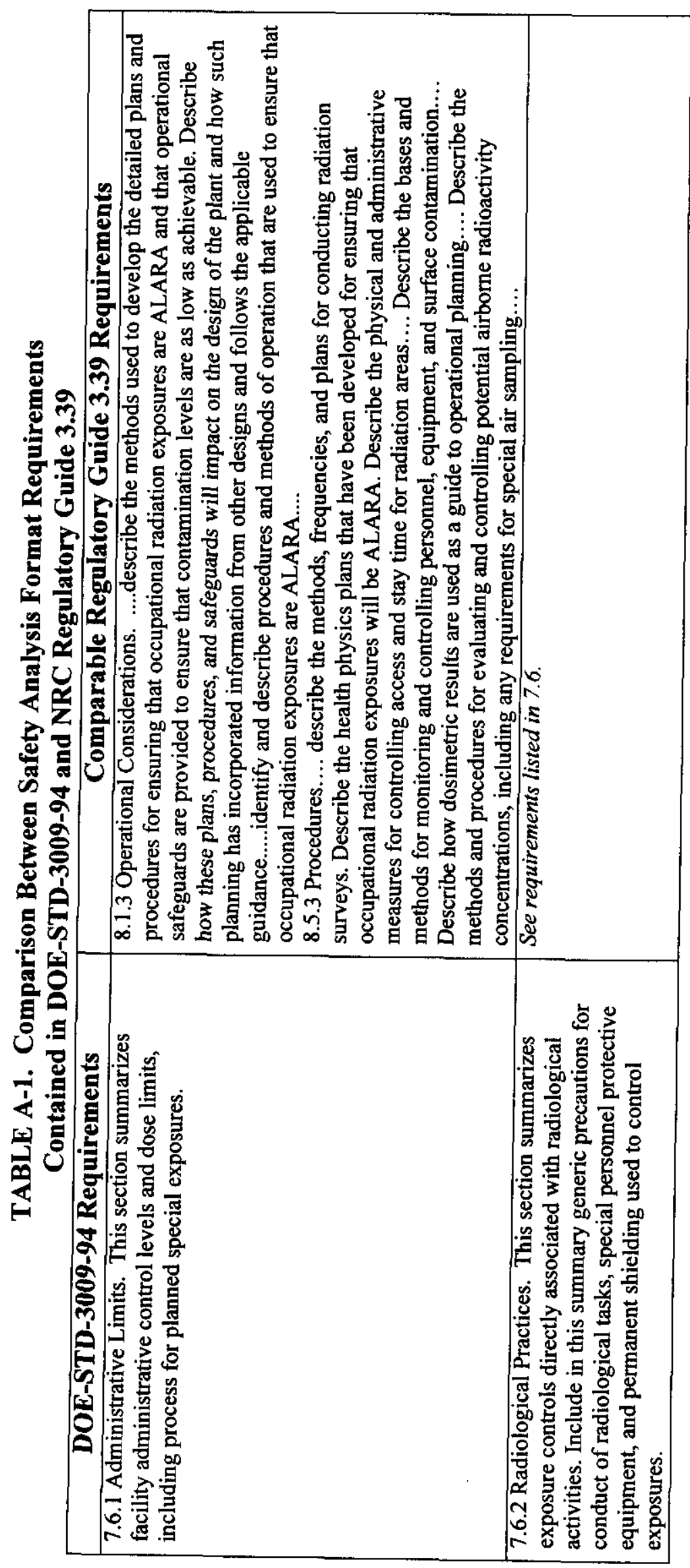


HNF-6533 Rev. 0

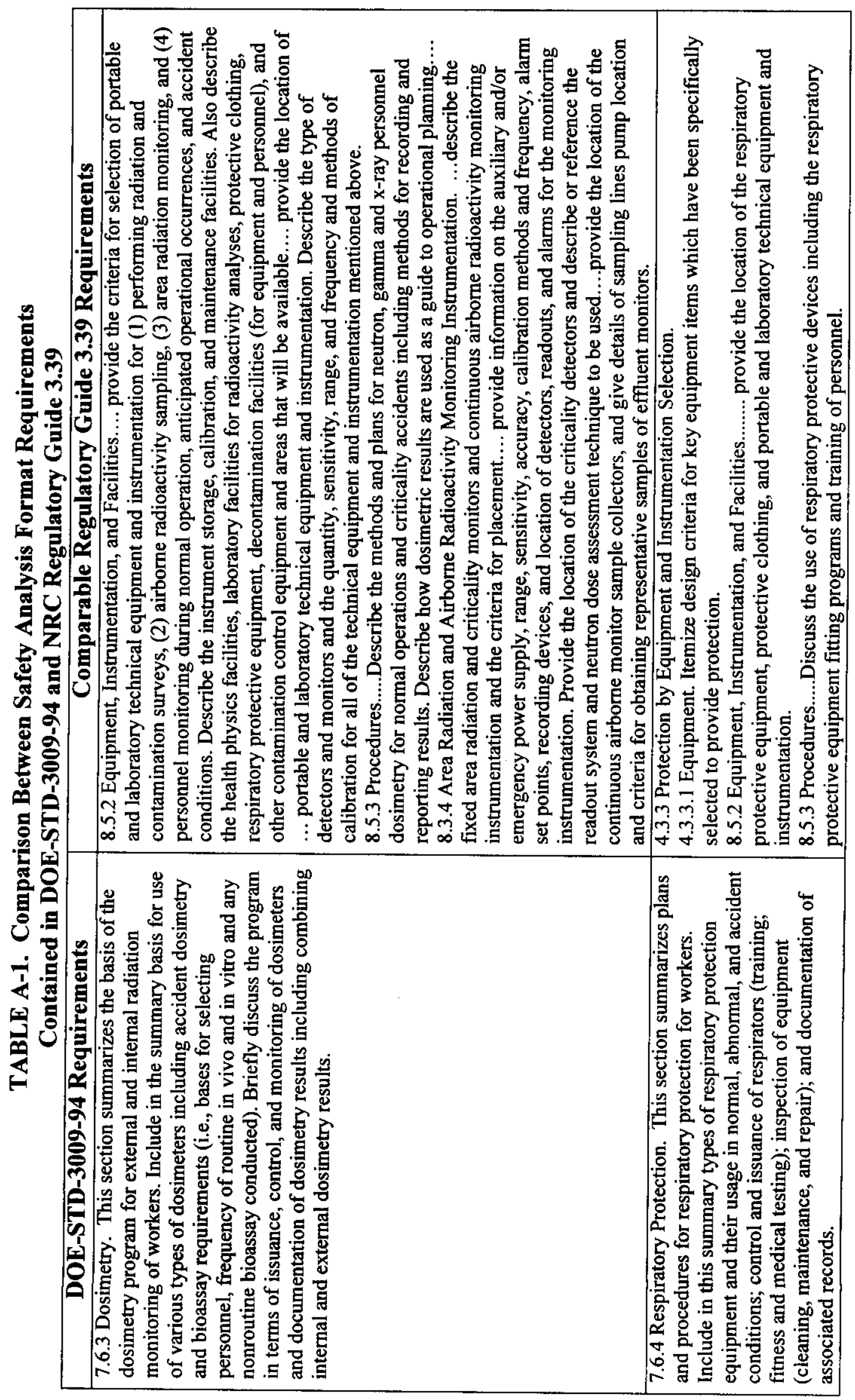


HNF-6533 Rev. 0

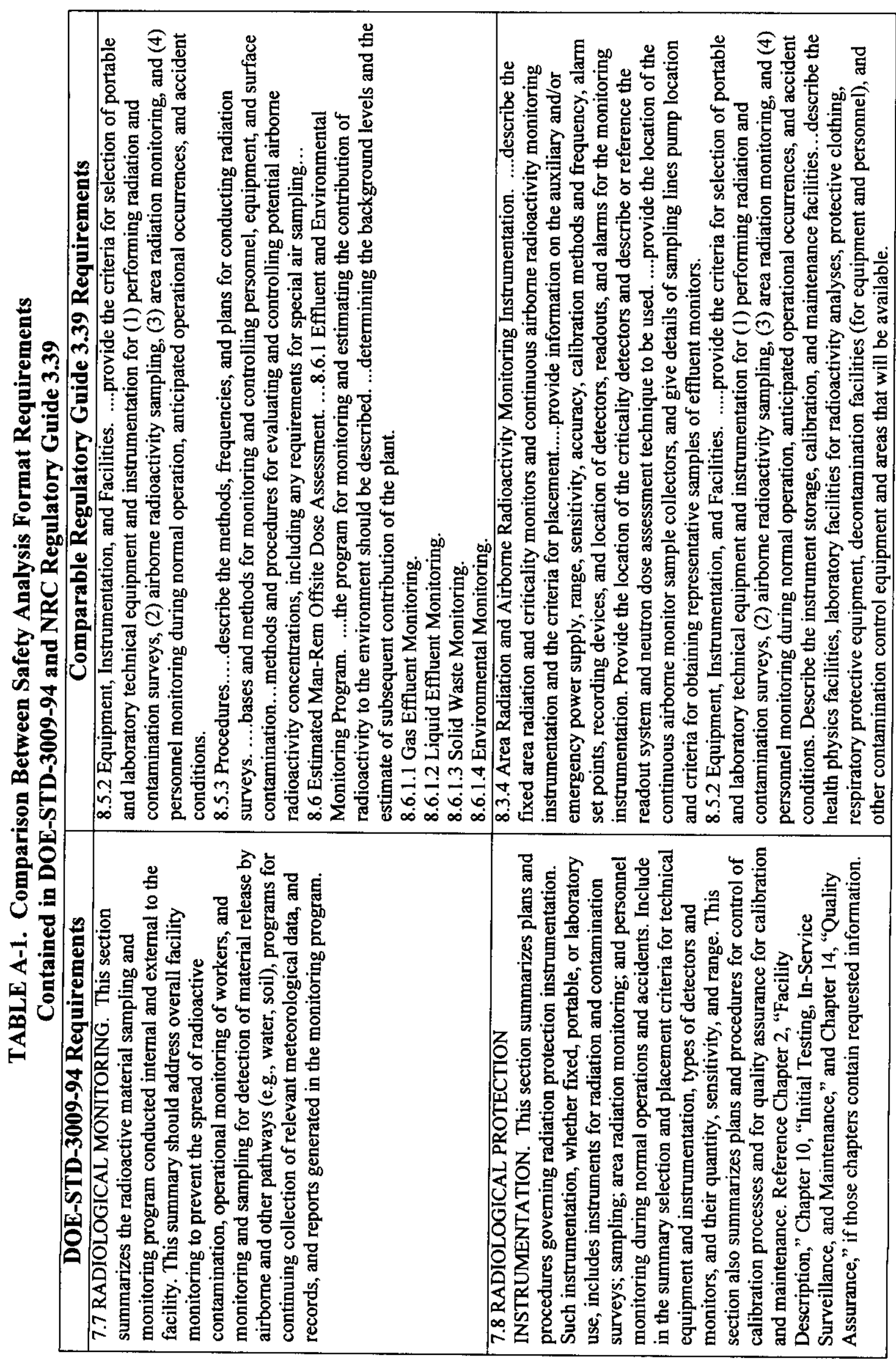




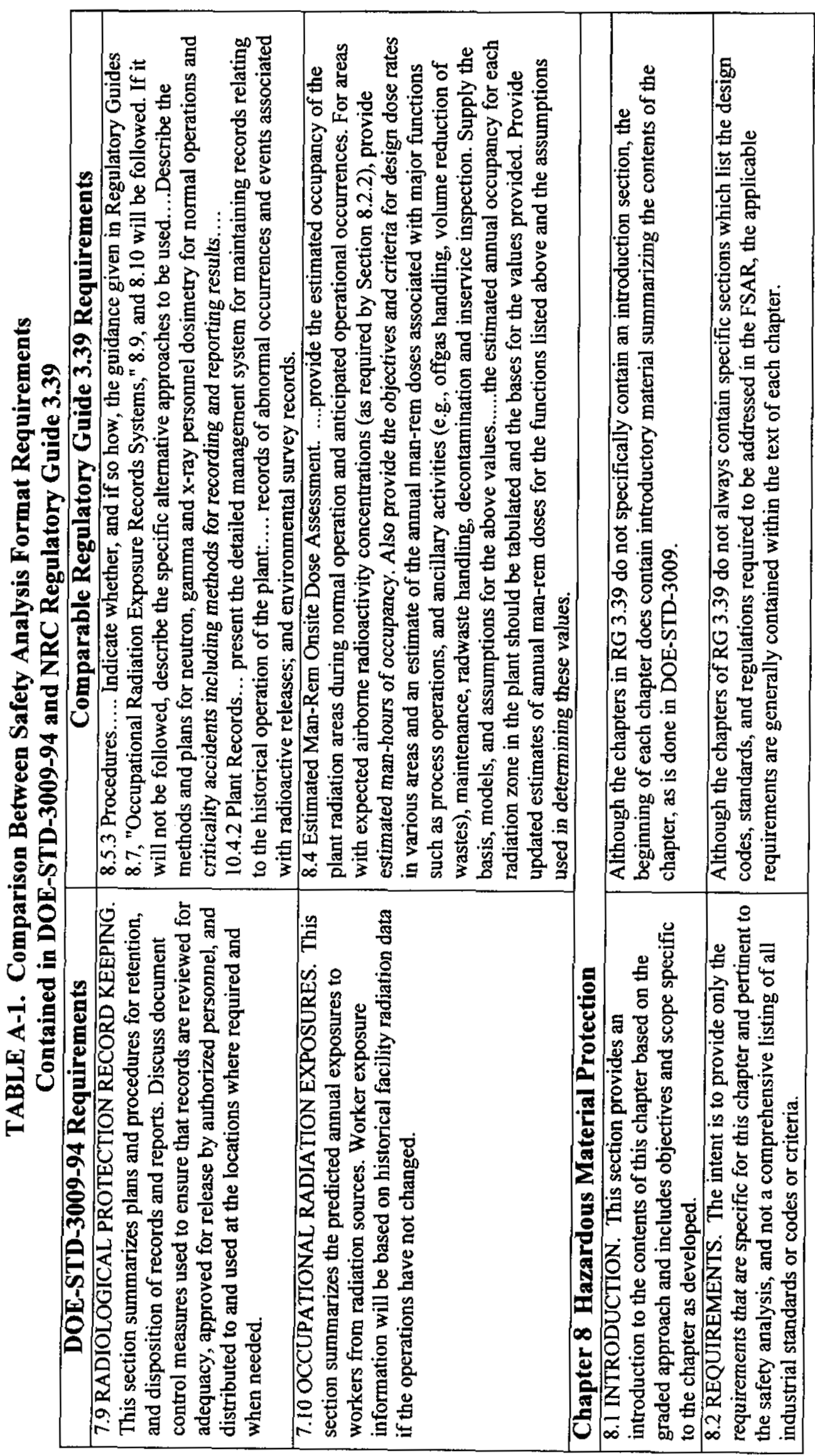




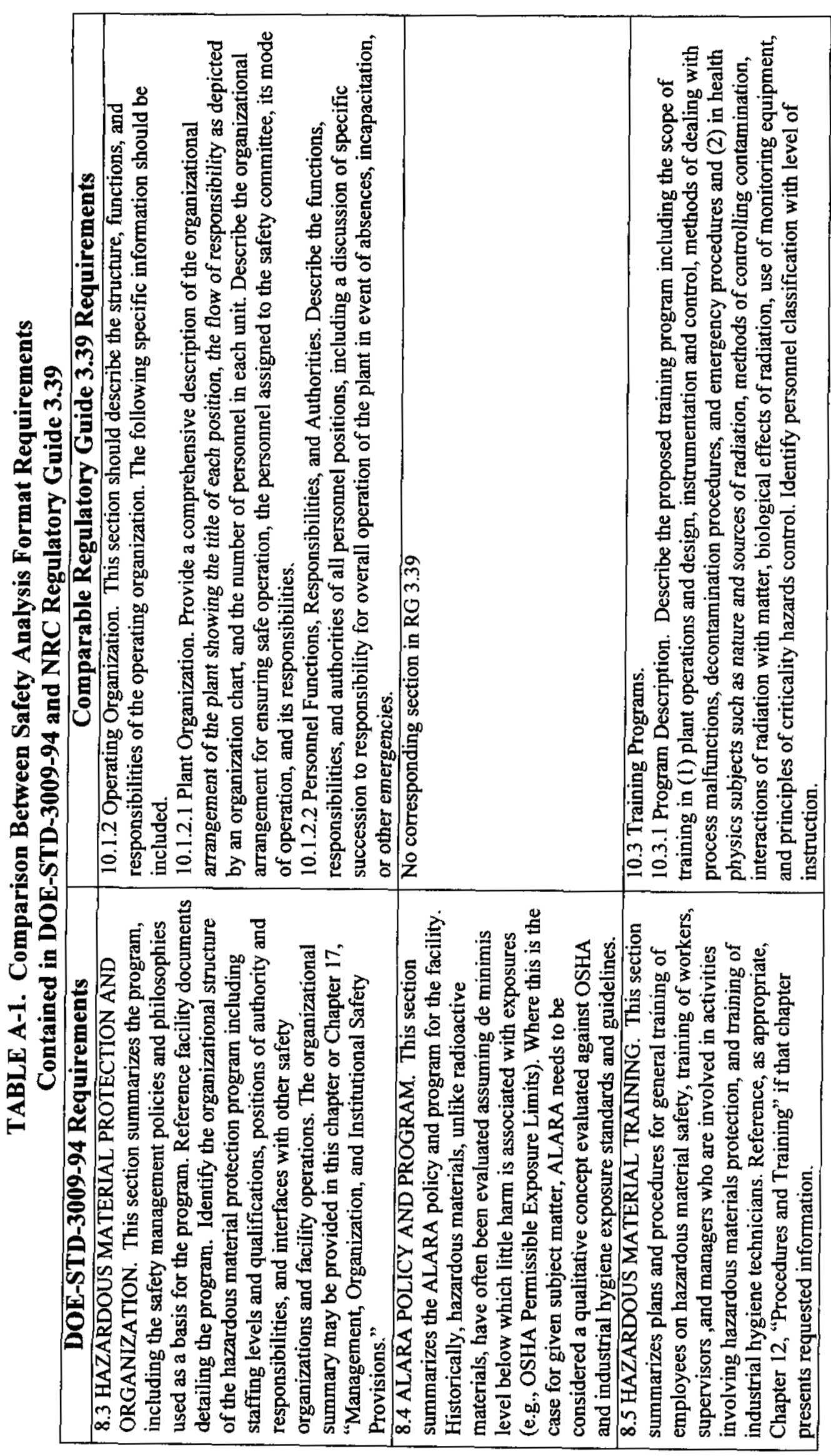


HNF-6533 Rev. 0

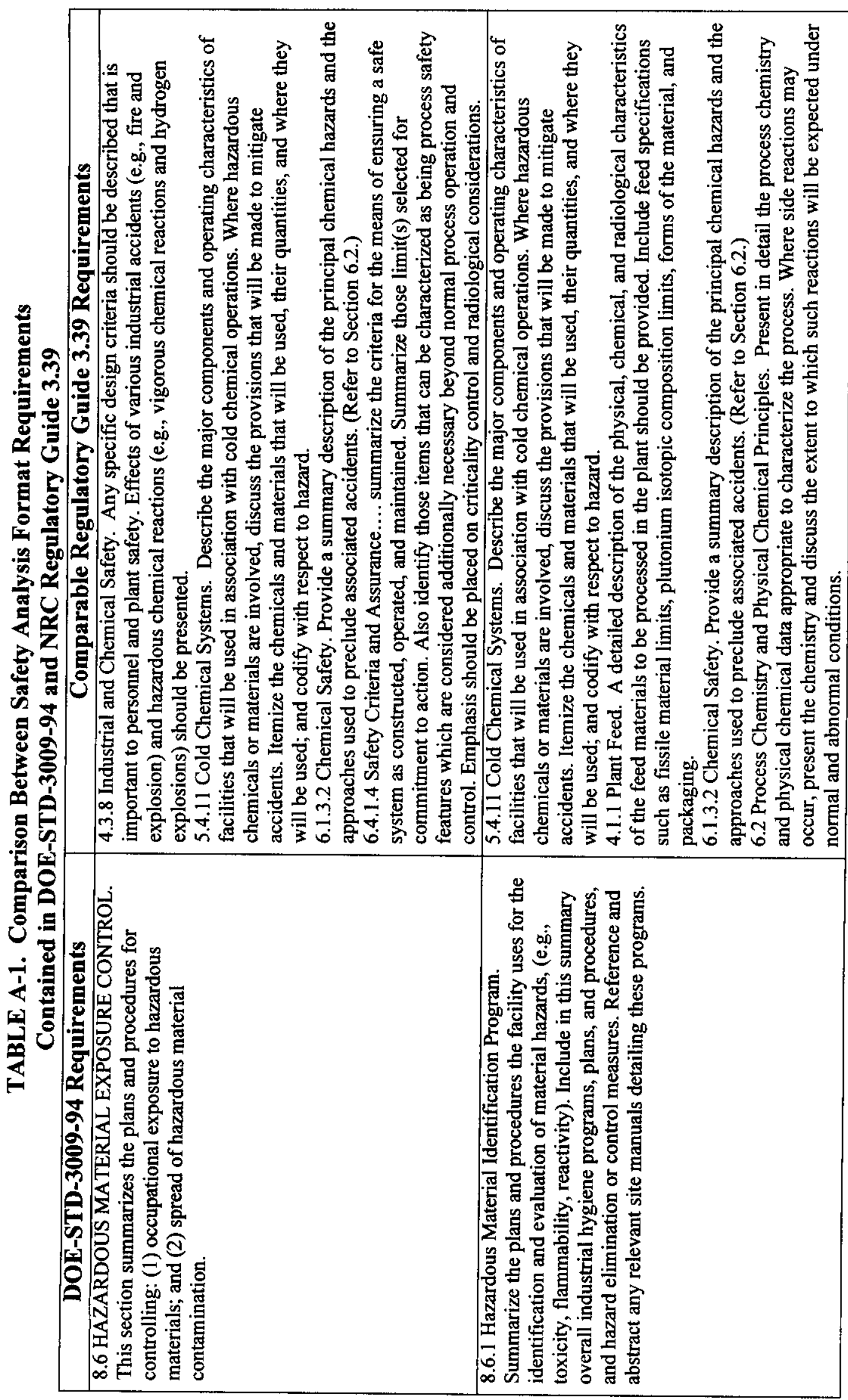


HNF-6533 Rev. 0

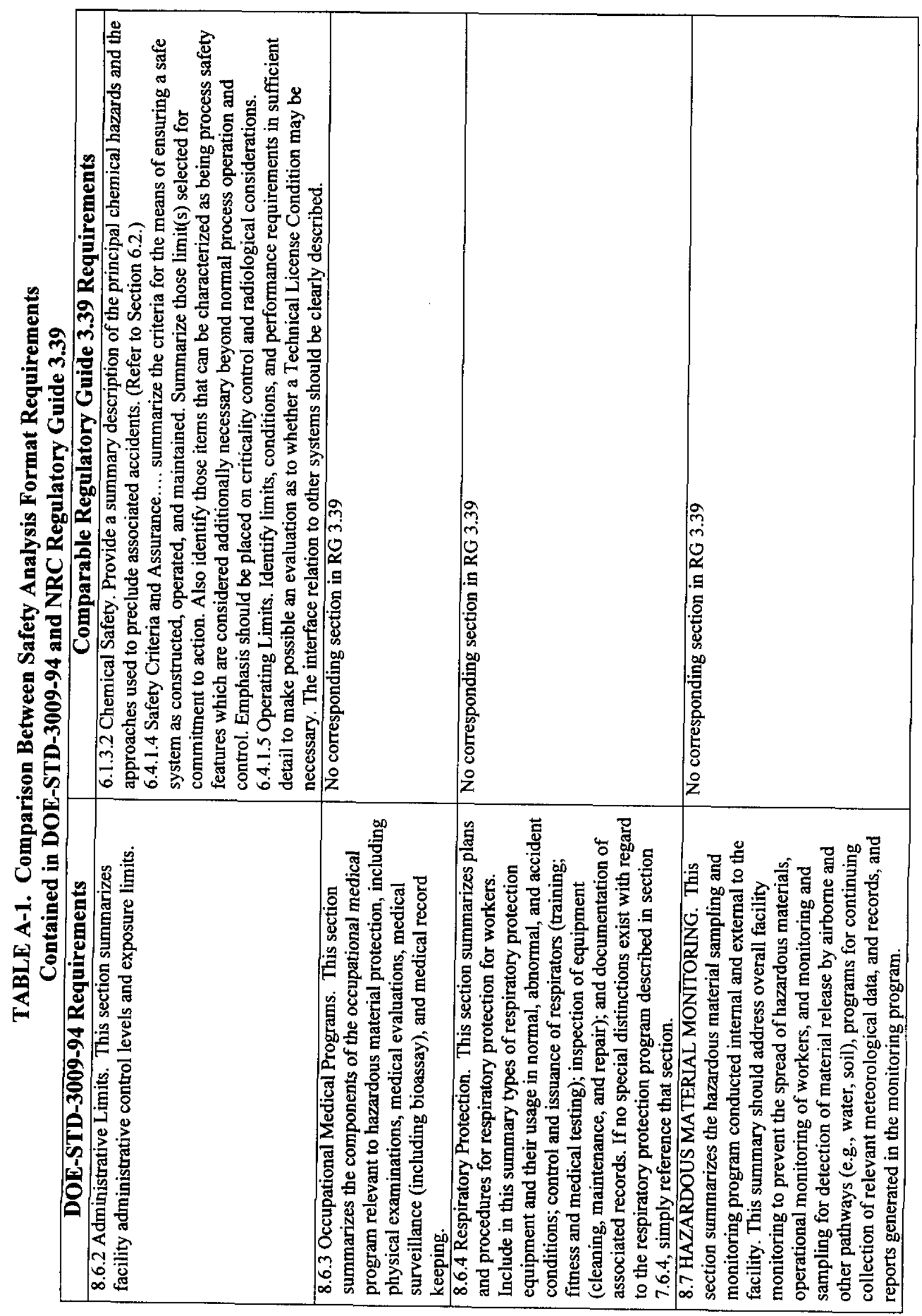


HNF-6533 Rev. 0

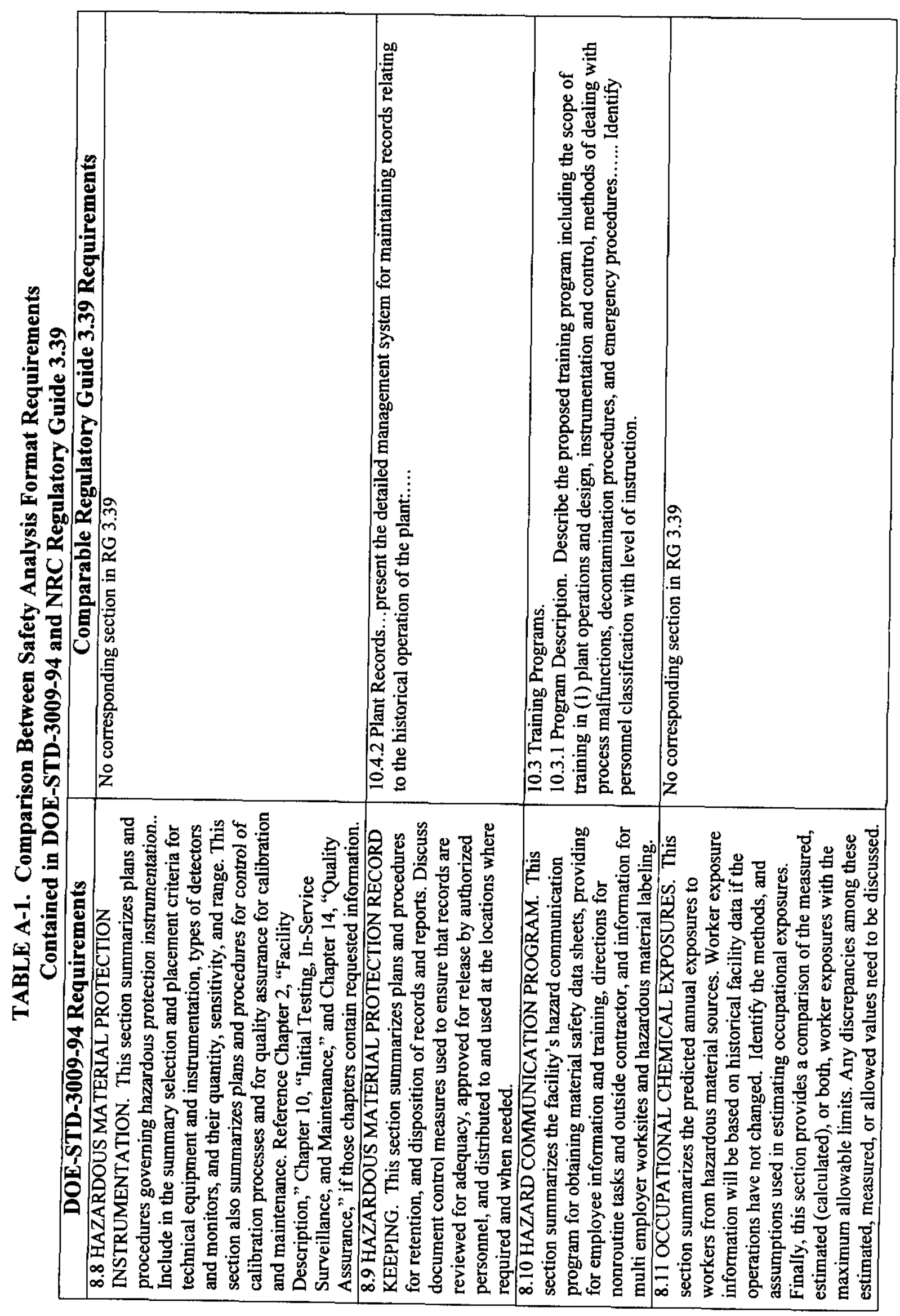


HNF-6533 Rev. 0

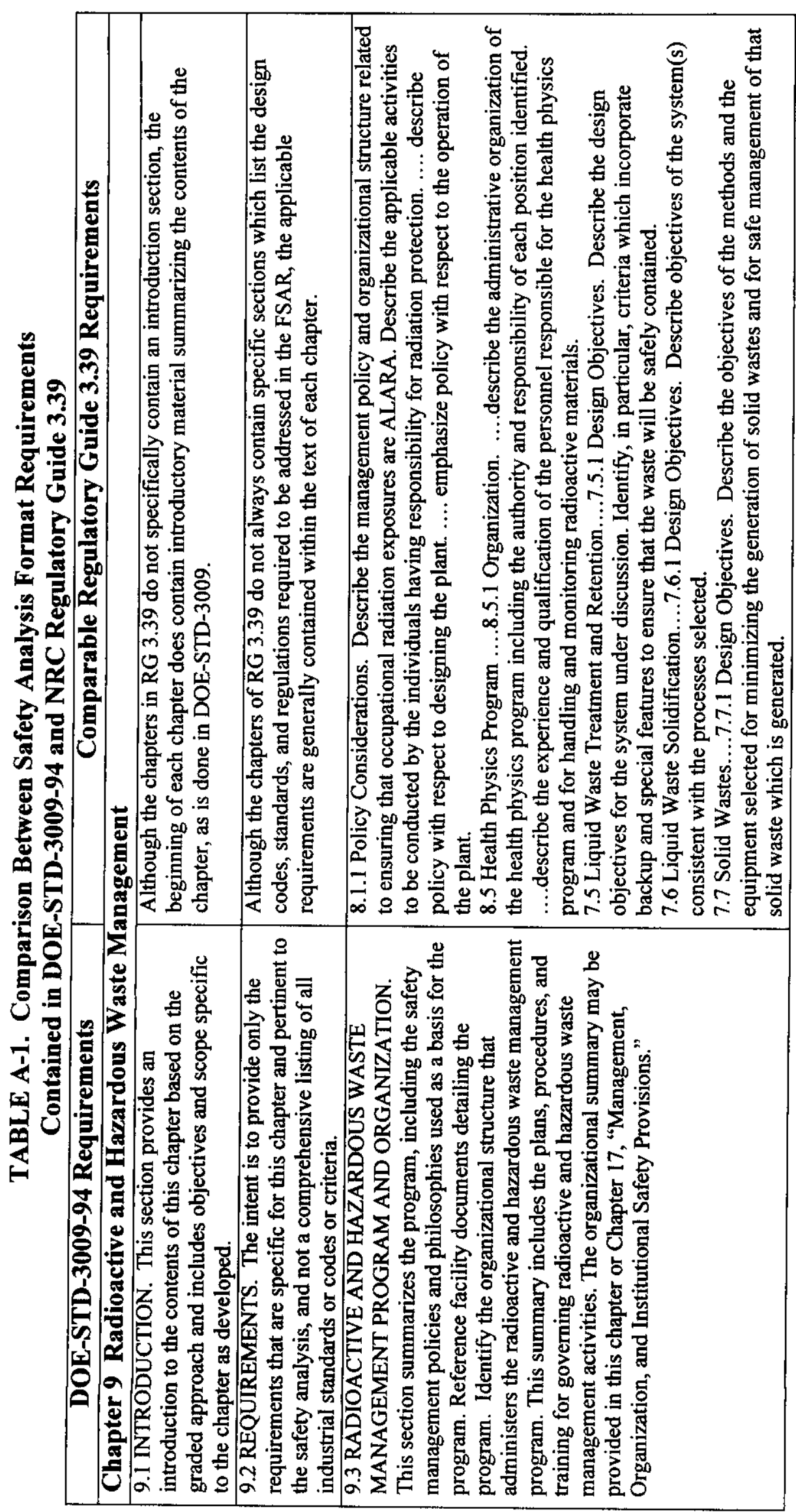


HNF-6533 Rev. 0

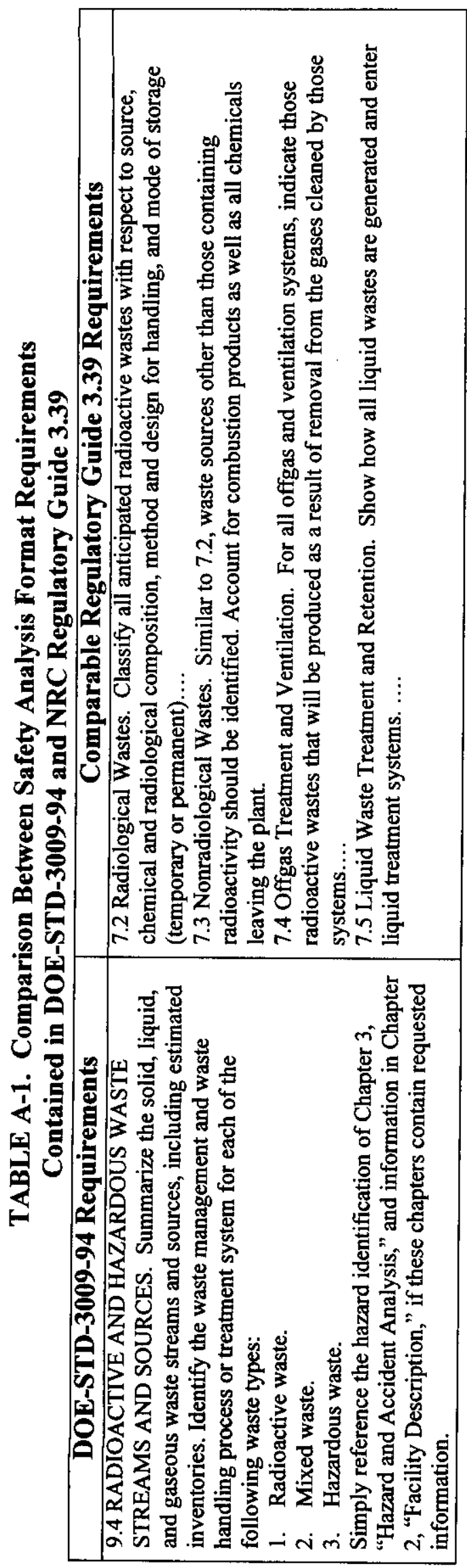


HNF-6533 Rev. 0

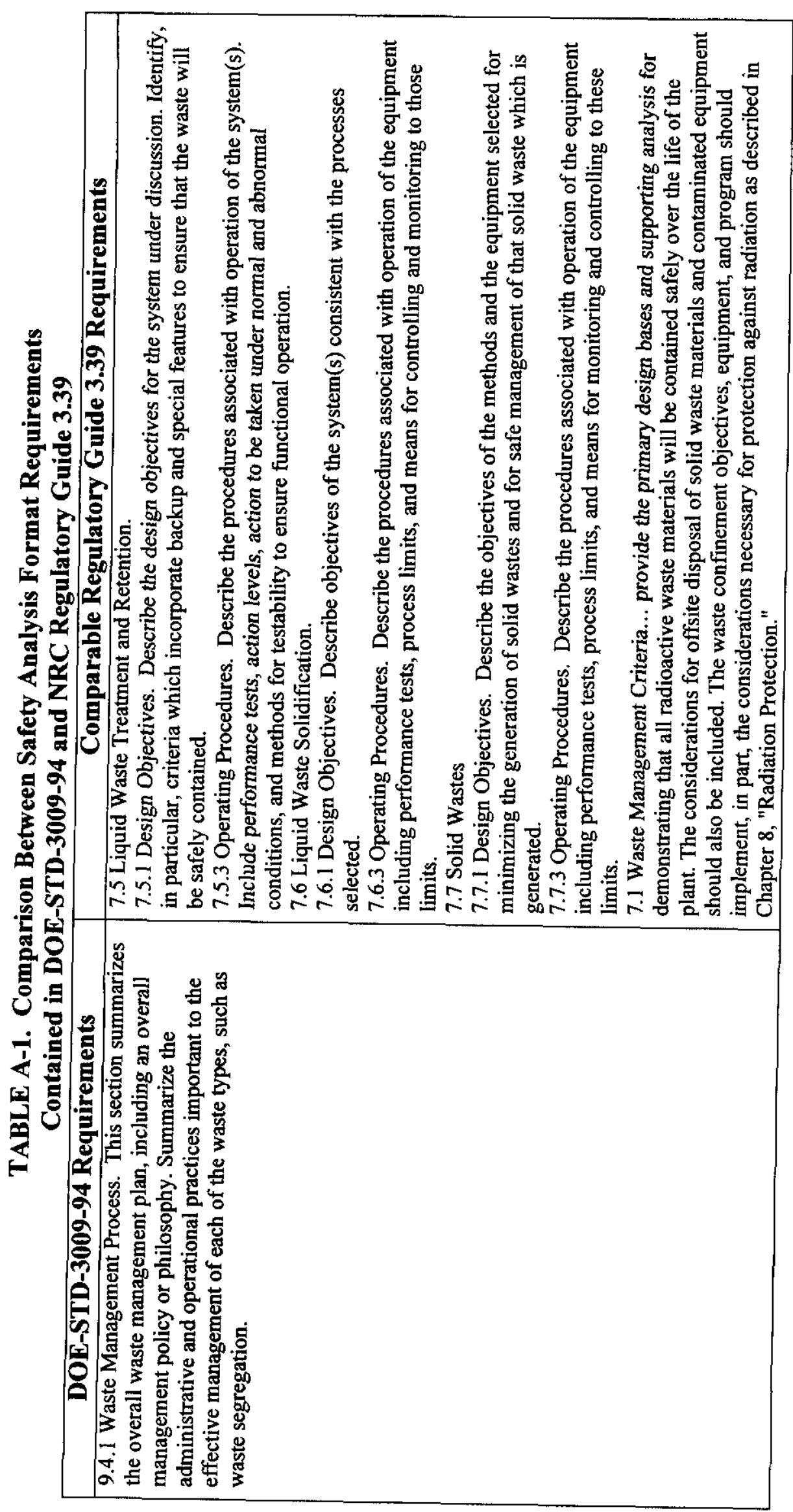


HNF-6533 Rev. 0

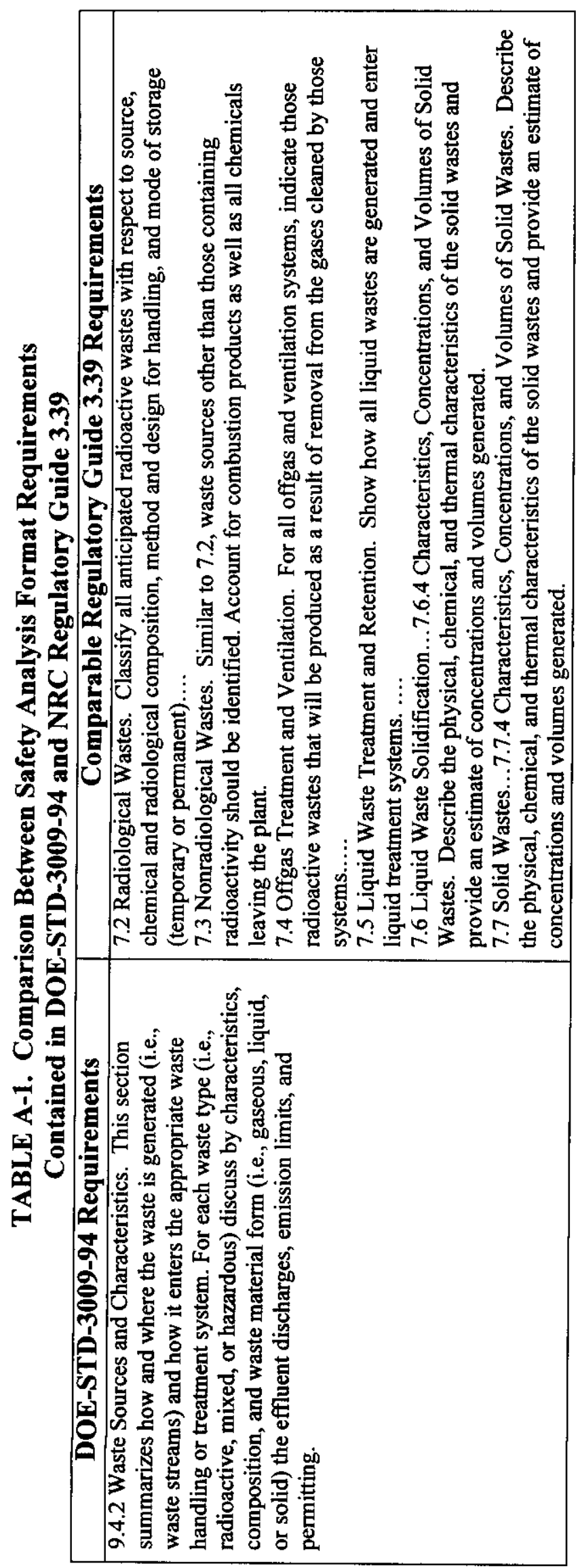




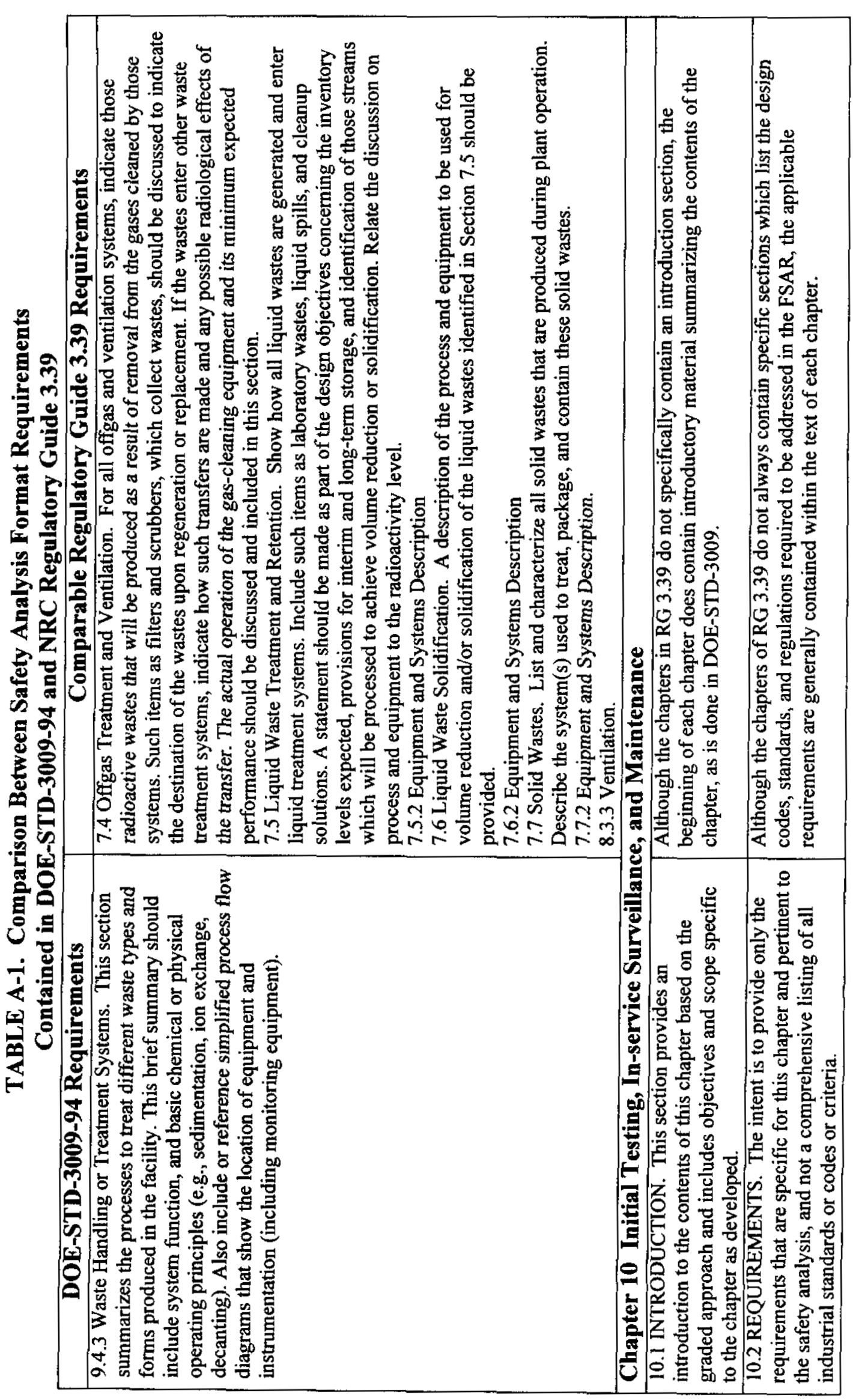




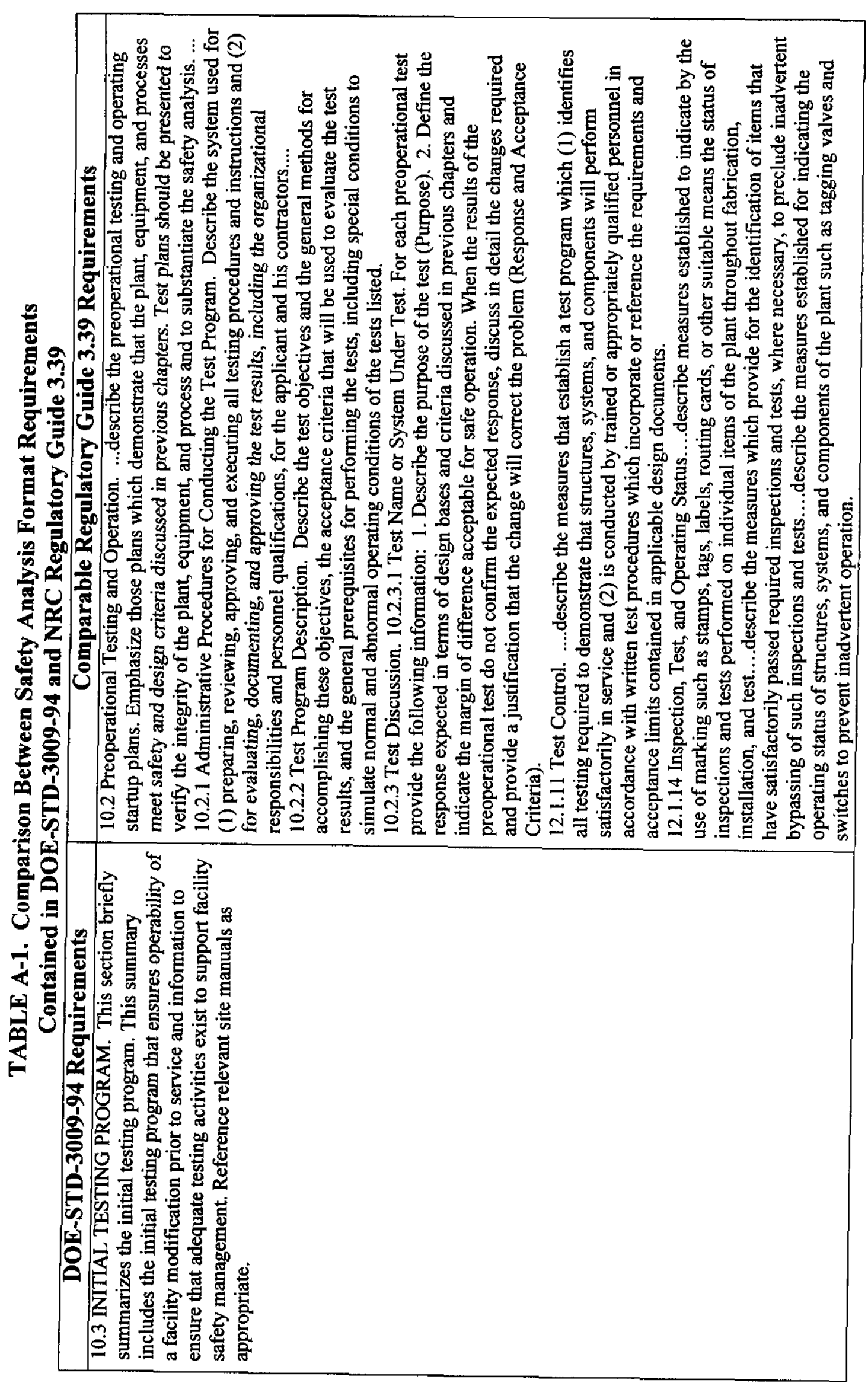


HNF-6533 Rev. 0

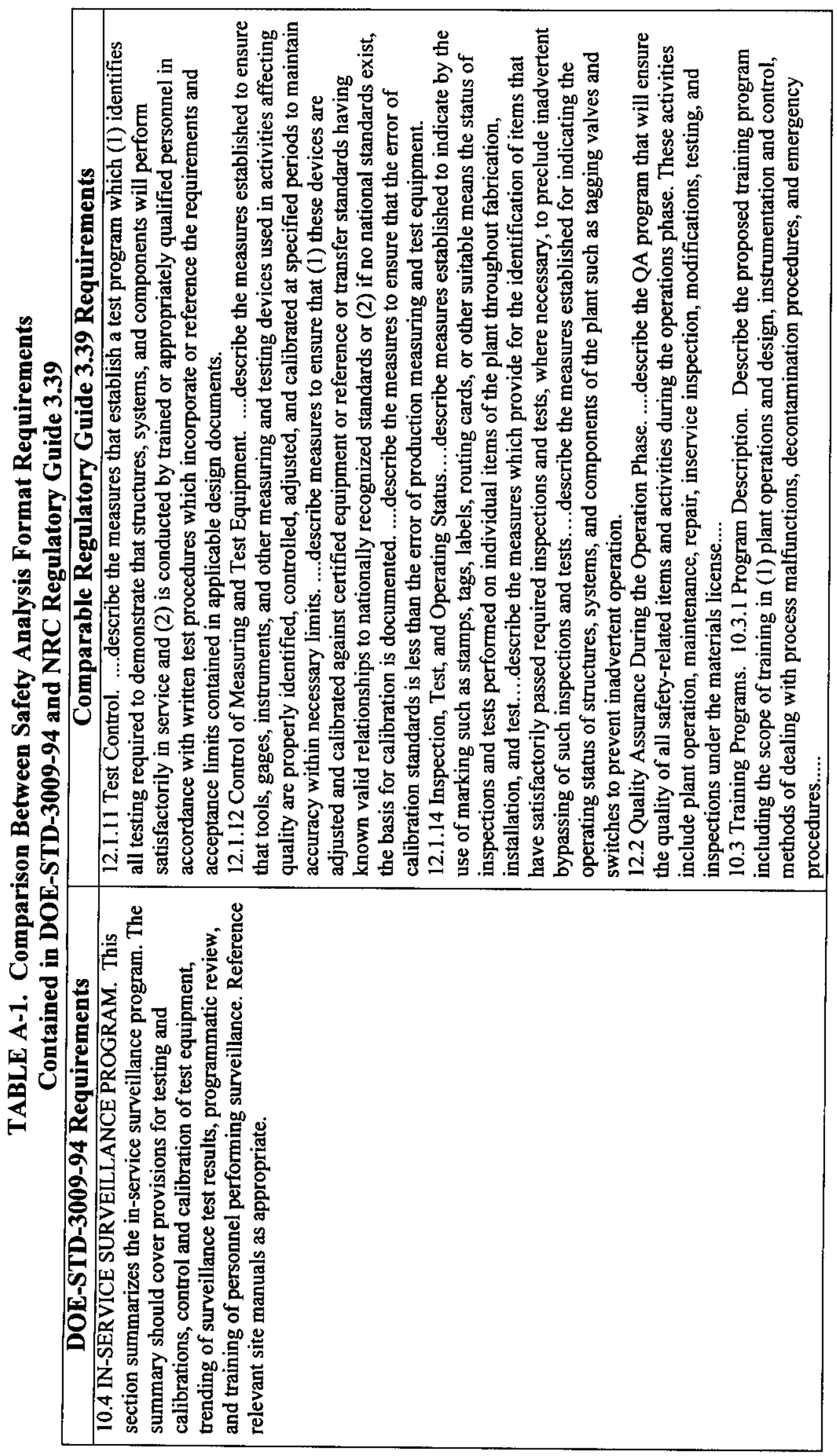




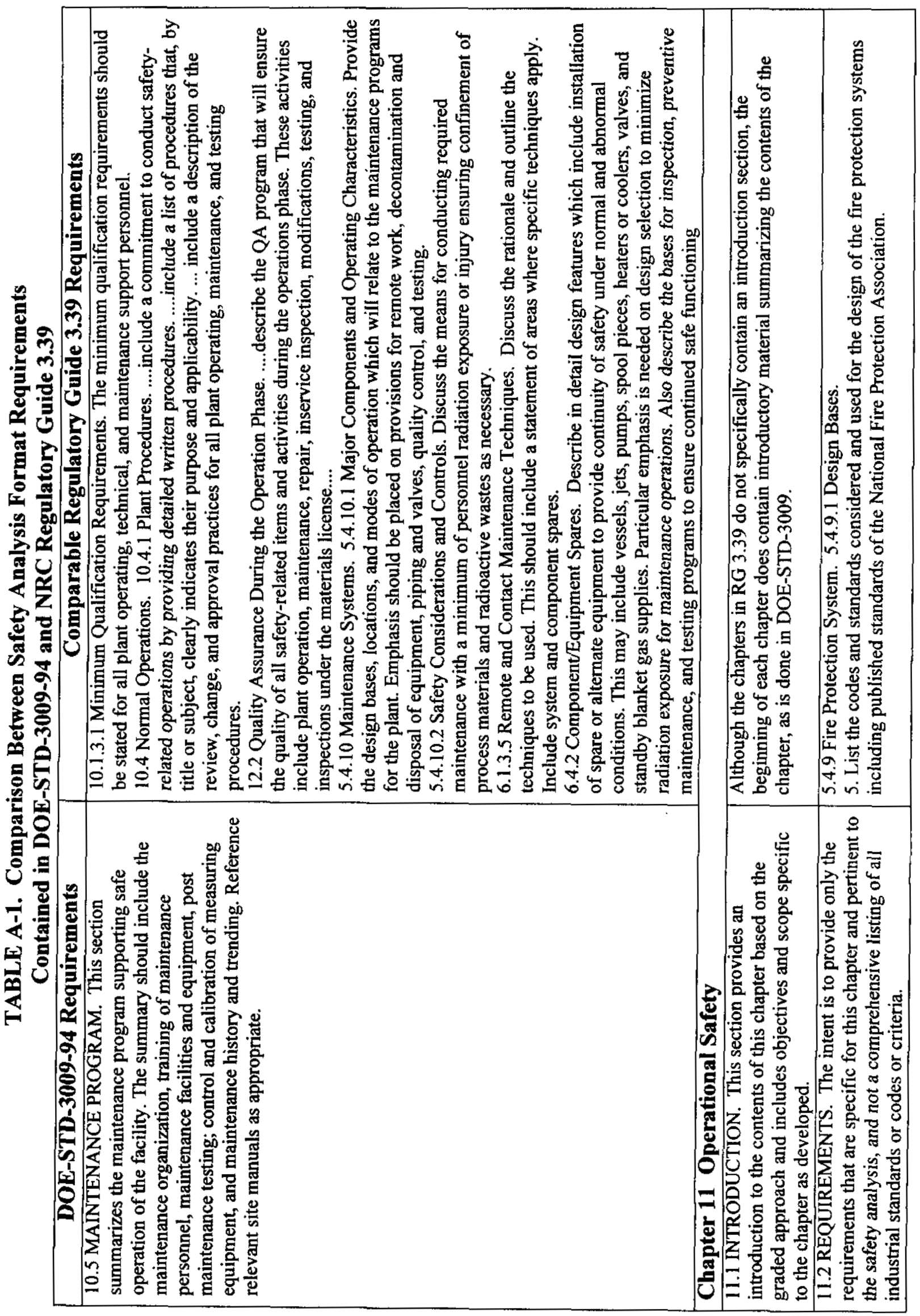




\section{HNF-6533 Rev. 0}

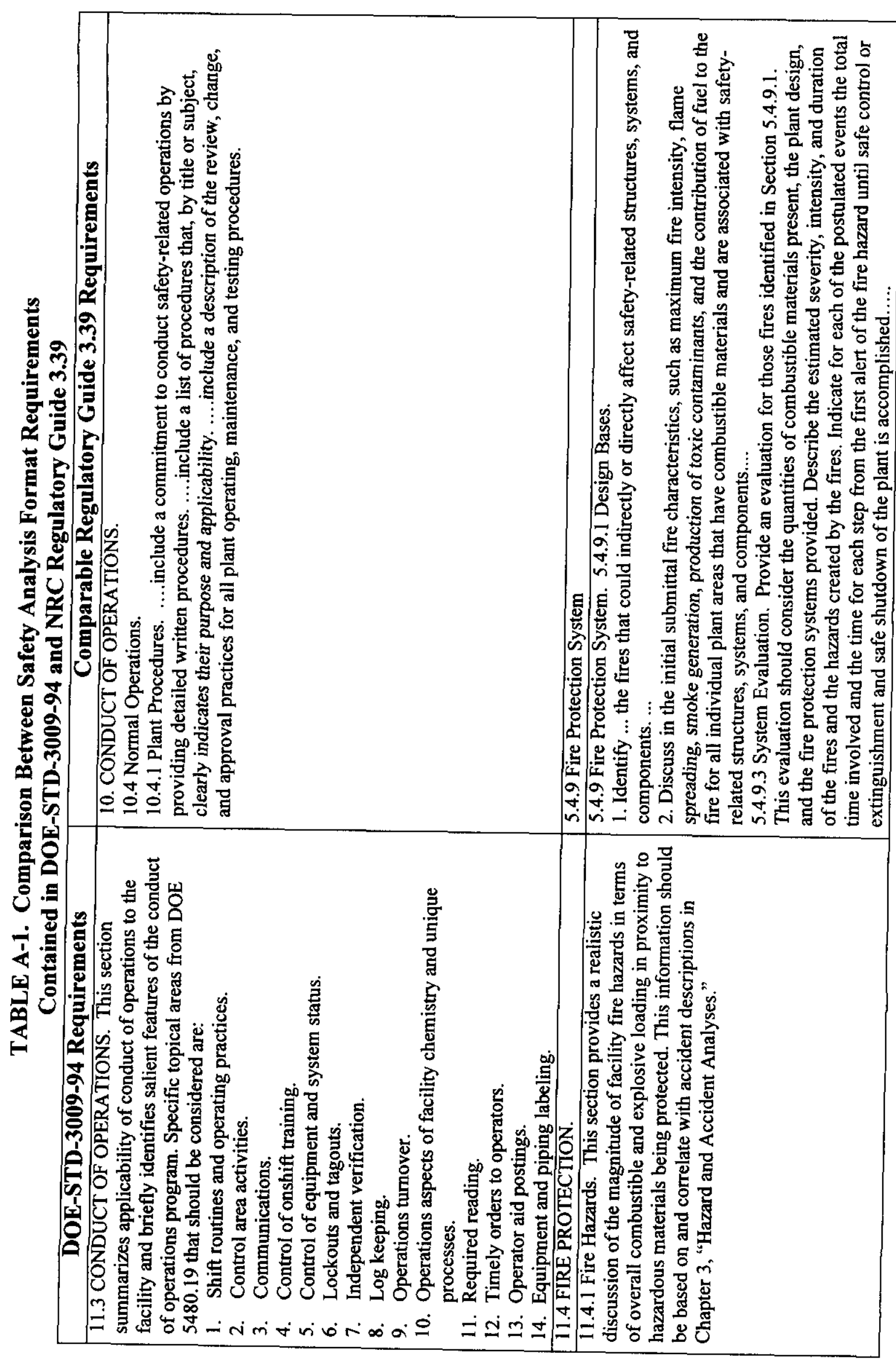


HNF-6533 Rev. 0

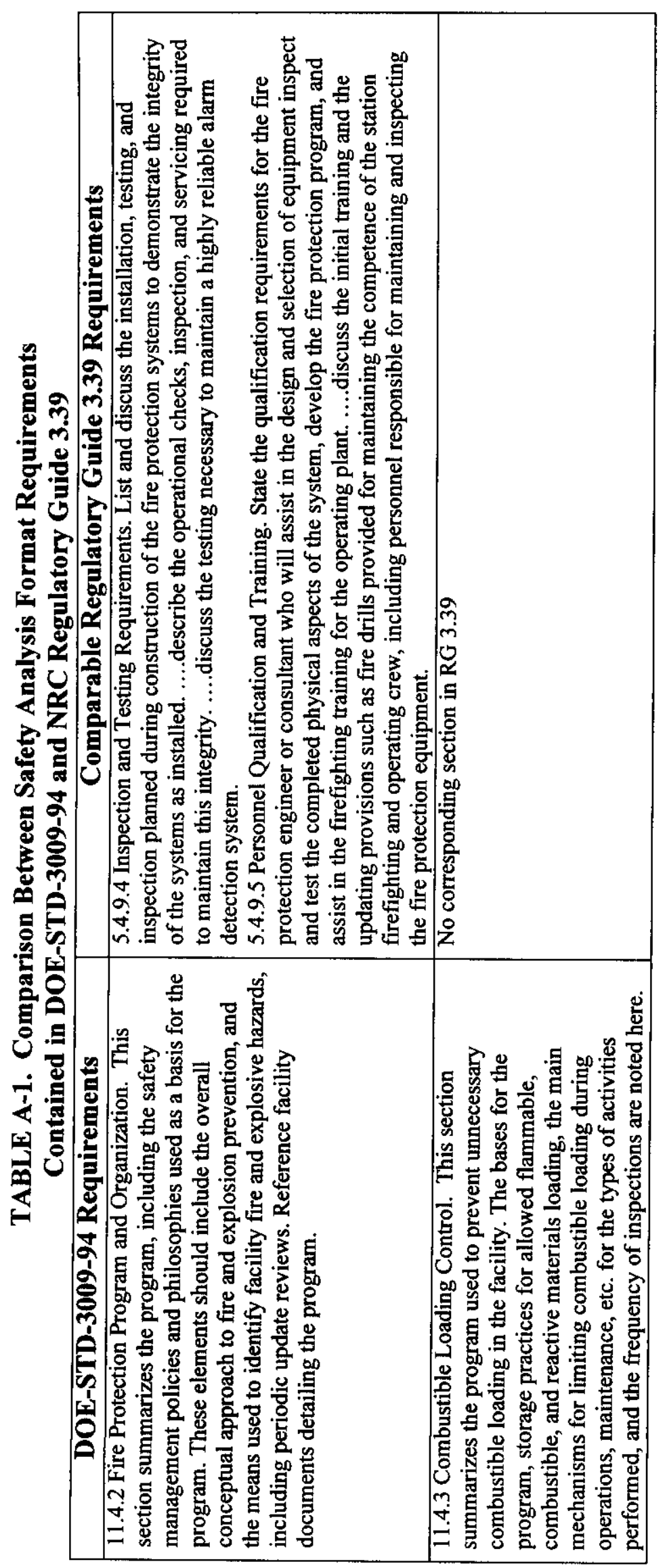




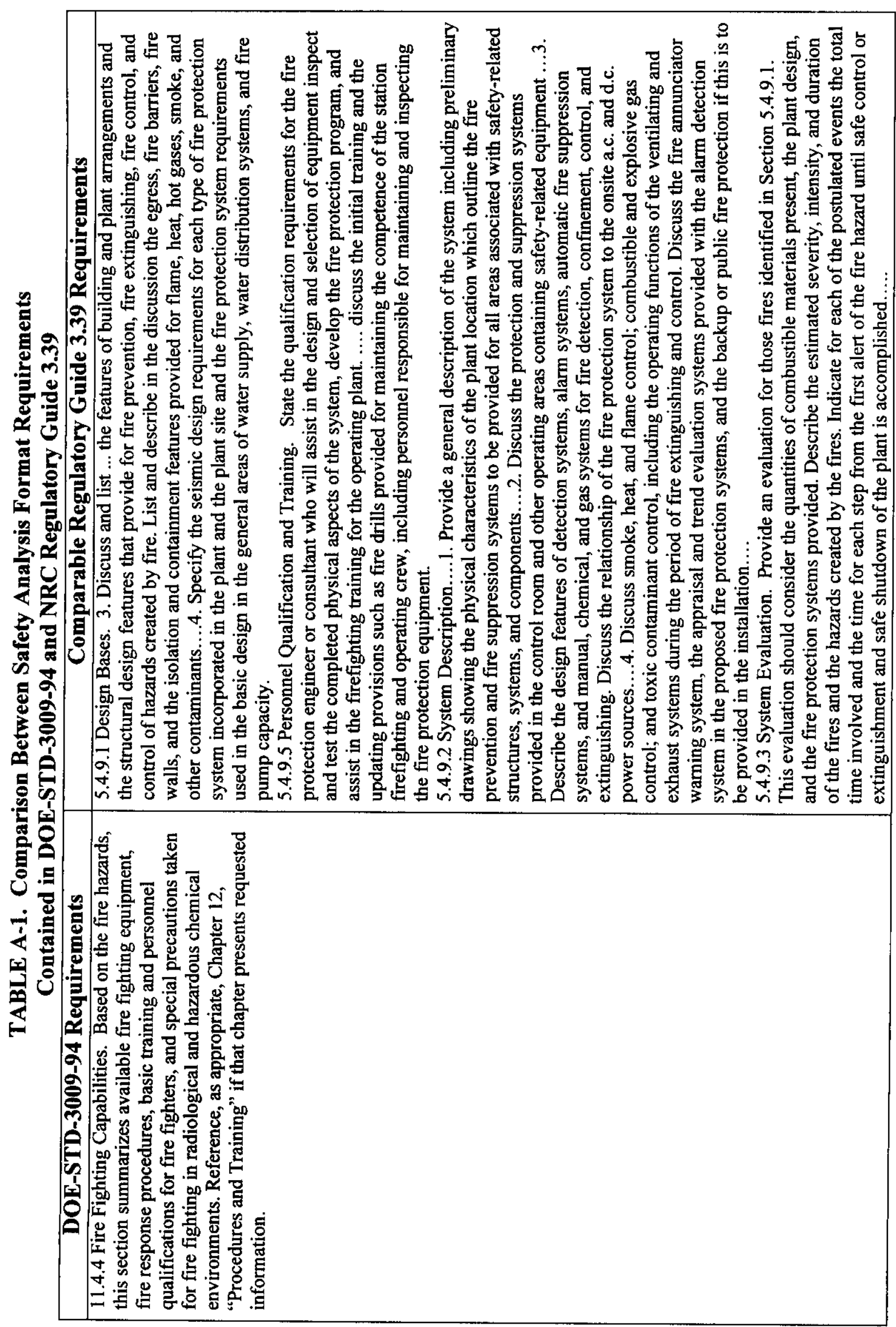


HNF-6533 Rev. 0

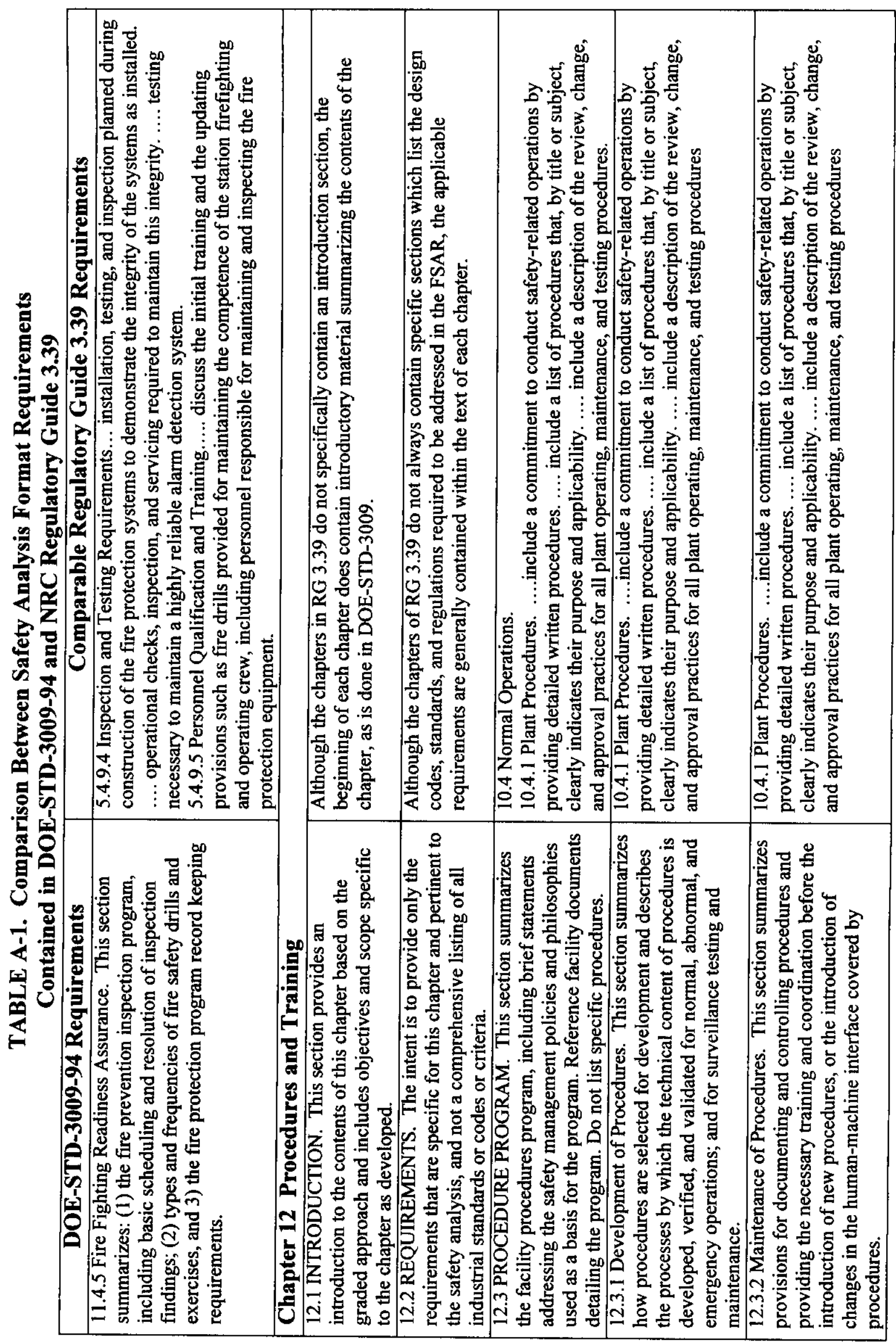


HNF-6533 Rev. 0

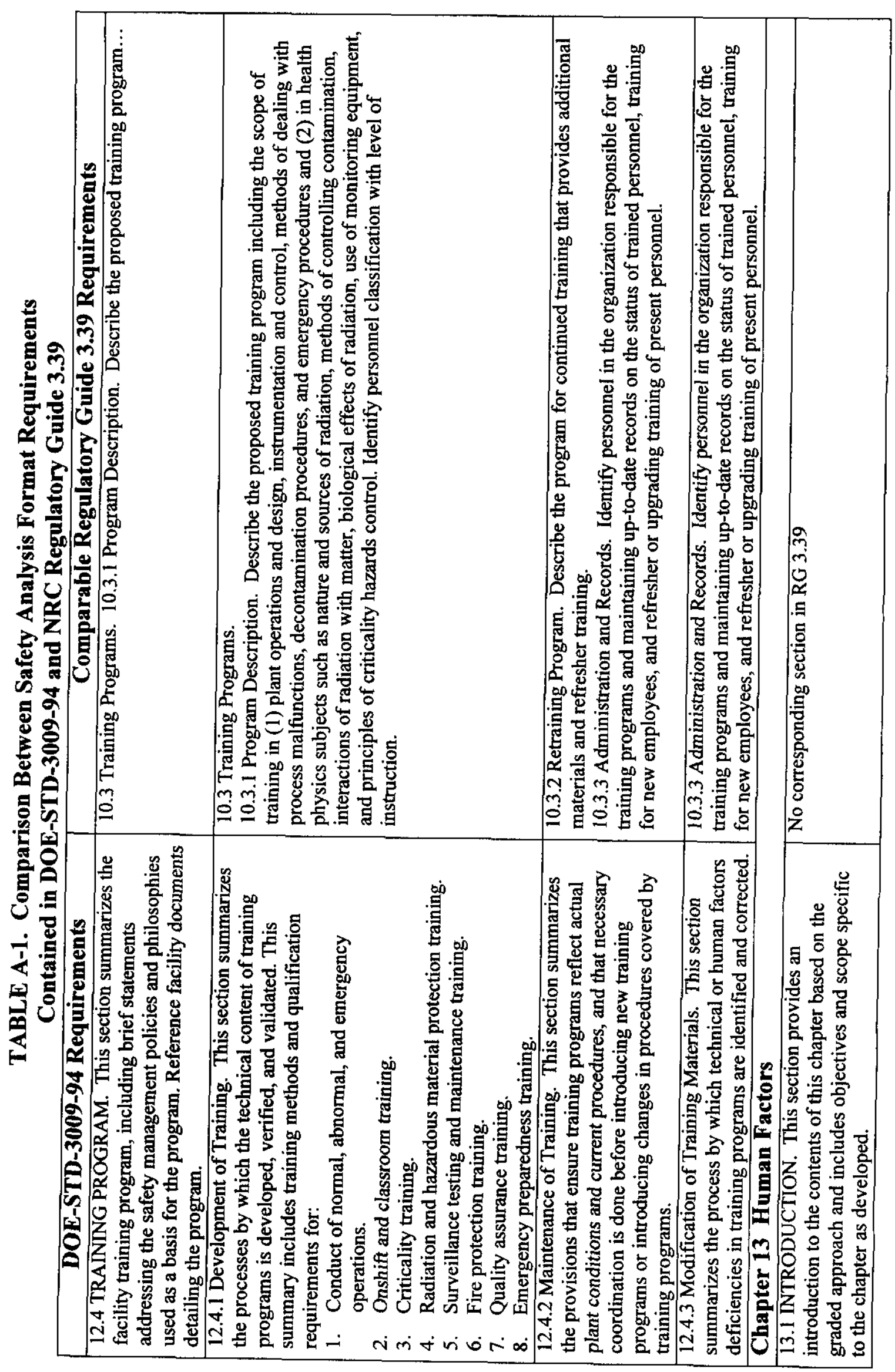


HNF-6533 Rev. 0

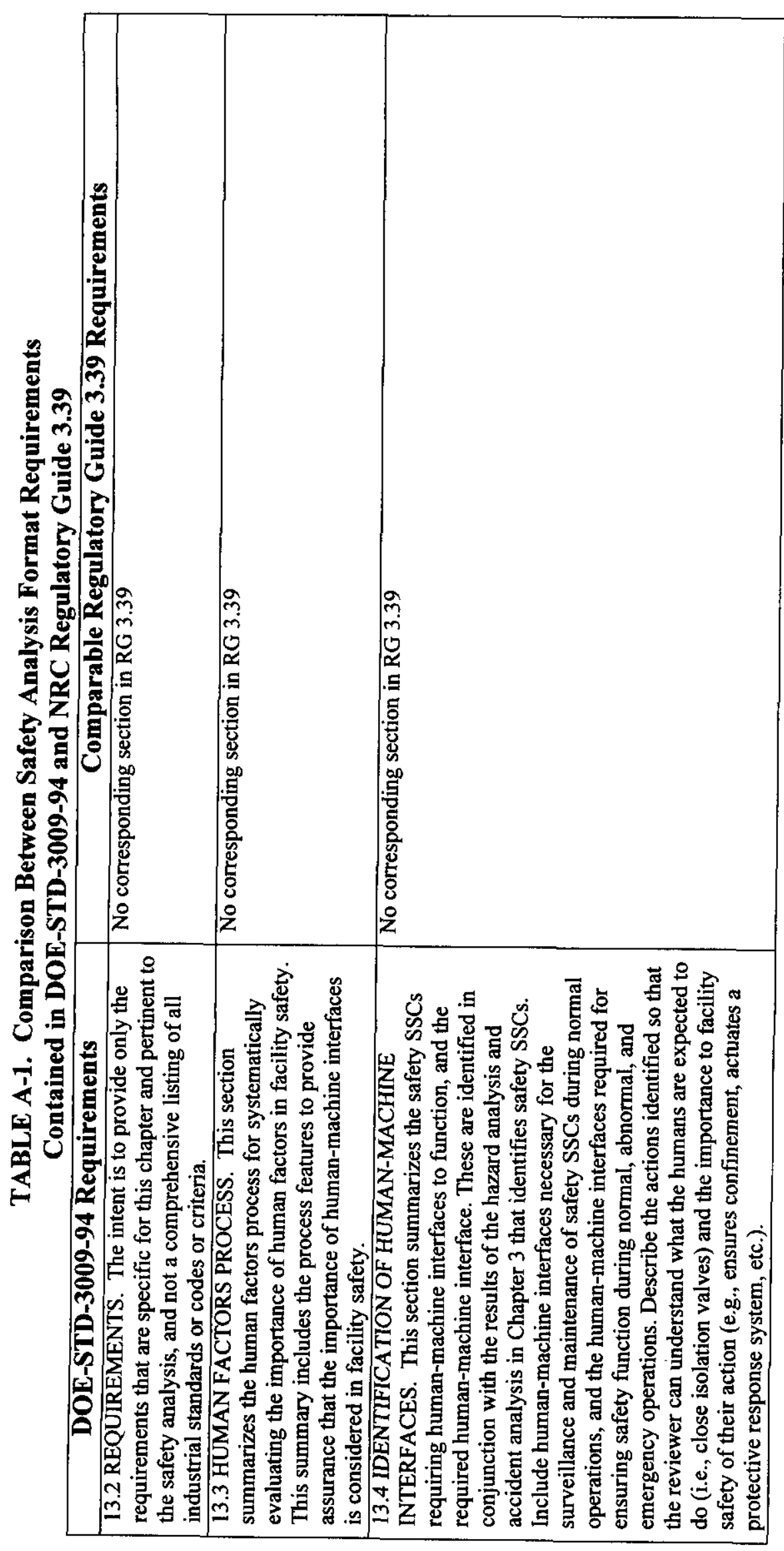




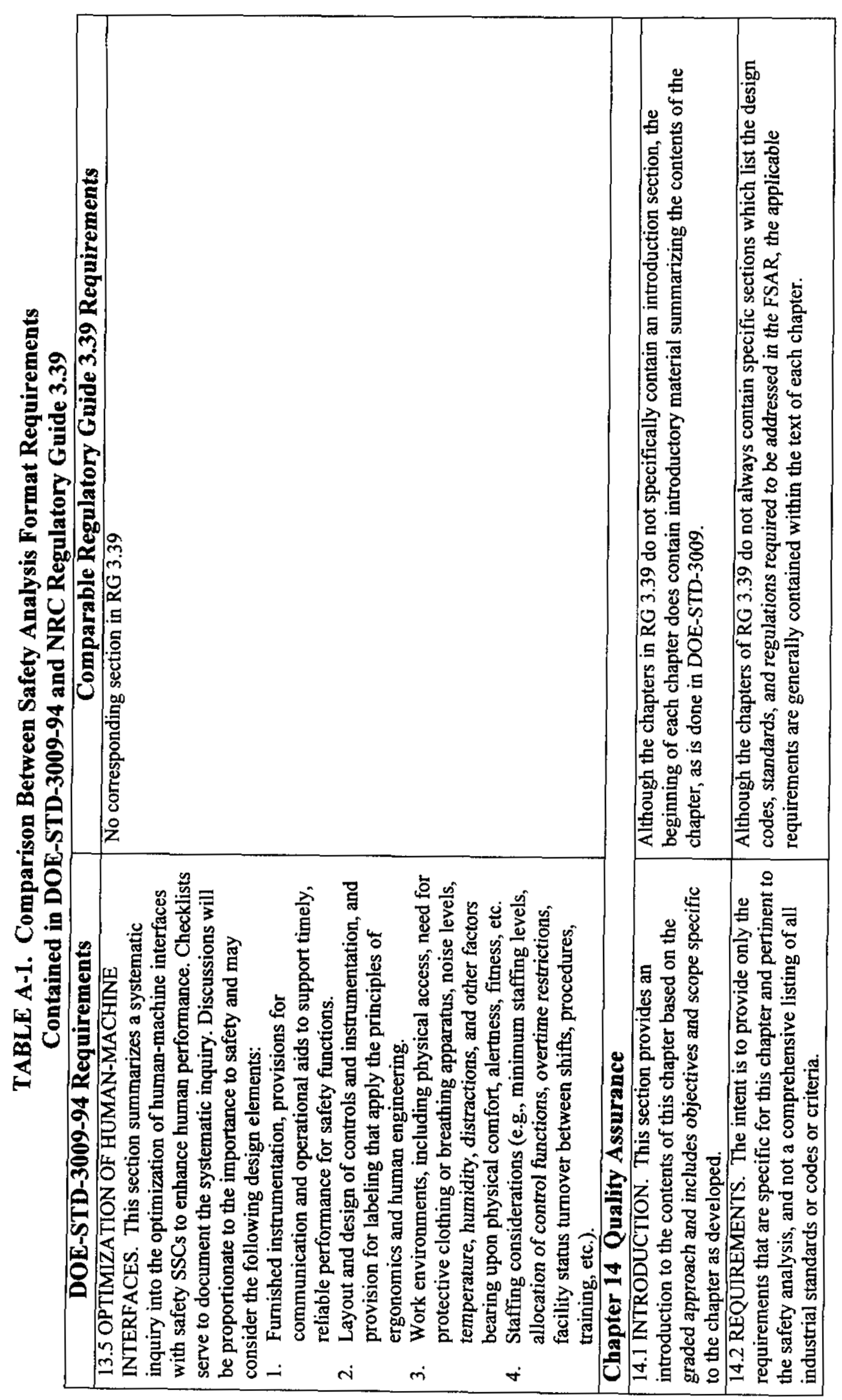


HNF-6533 Rev. 0

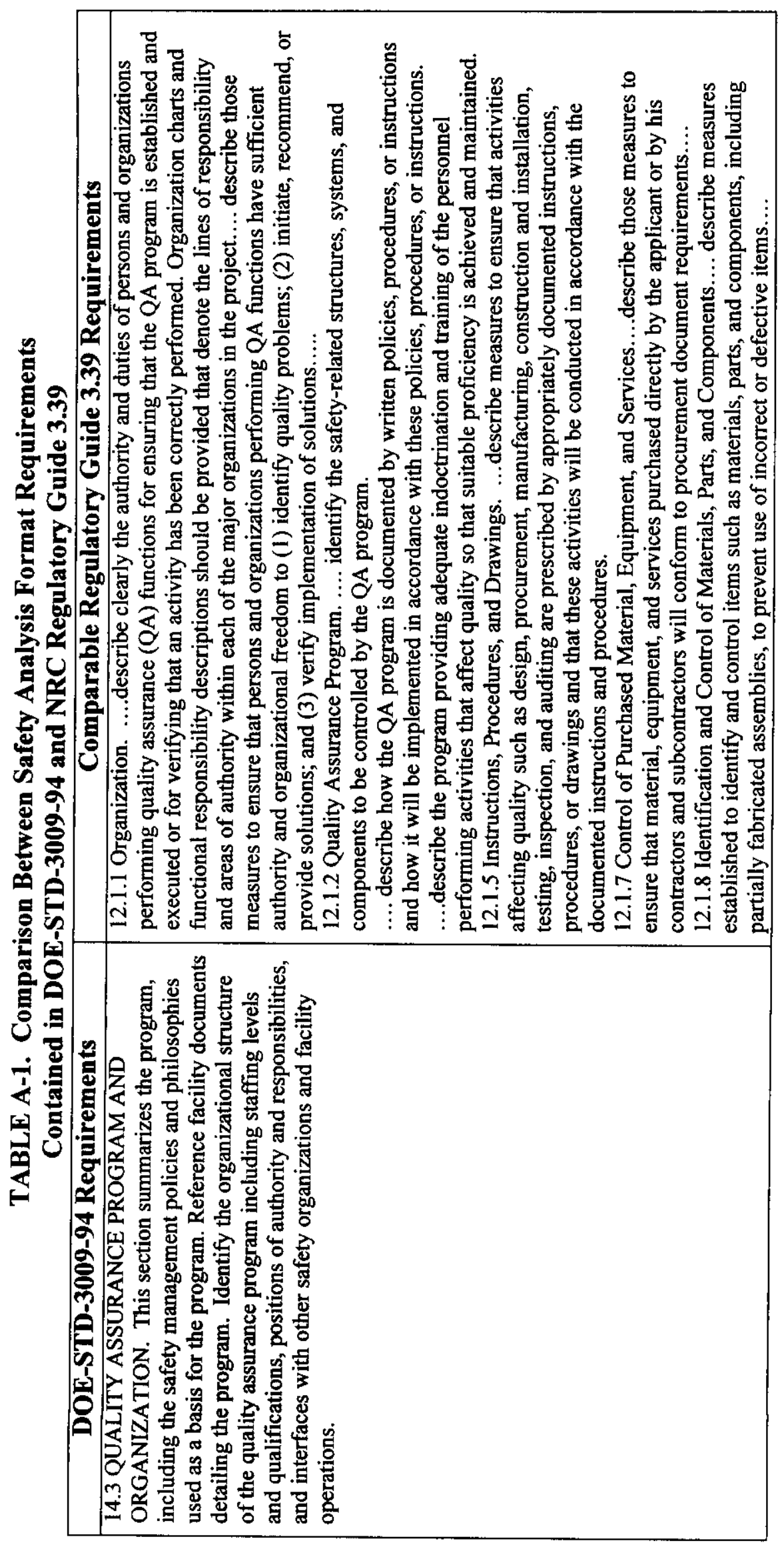


HNF-6533 Rev. 0

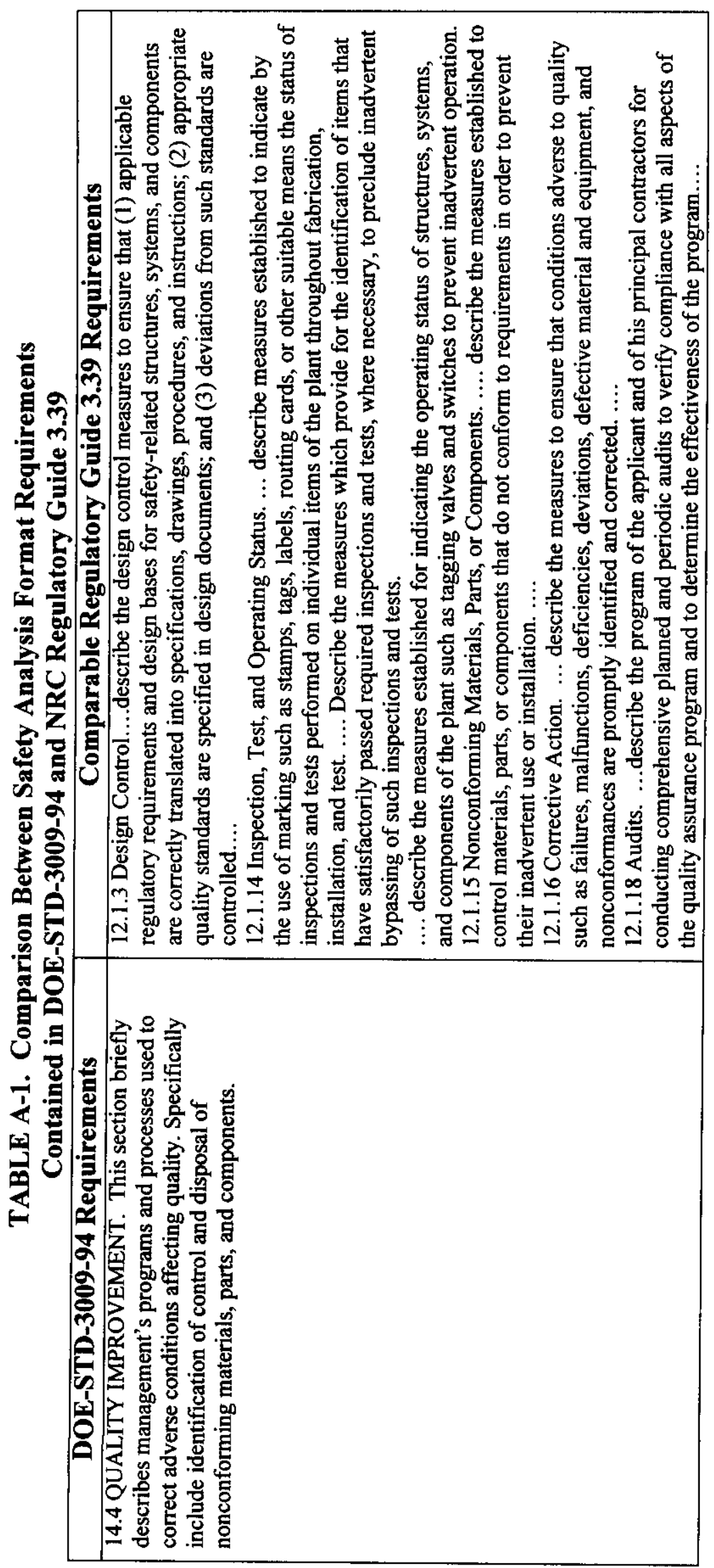


HNF-6533 Rev. 0

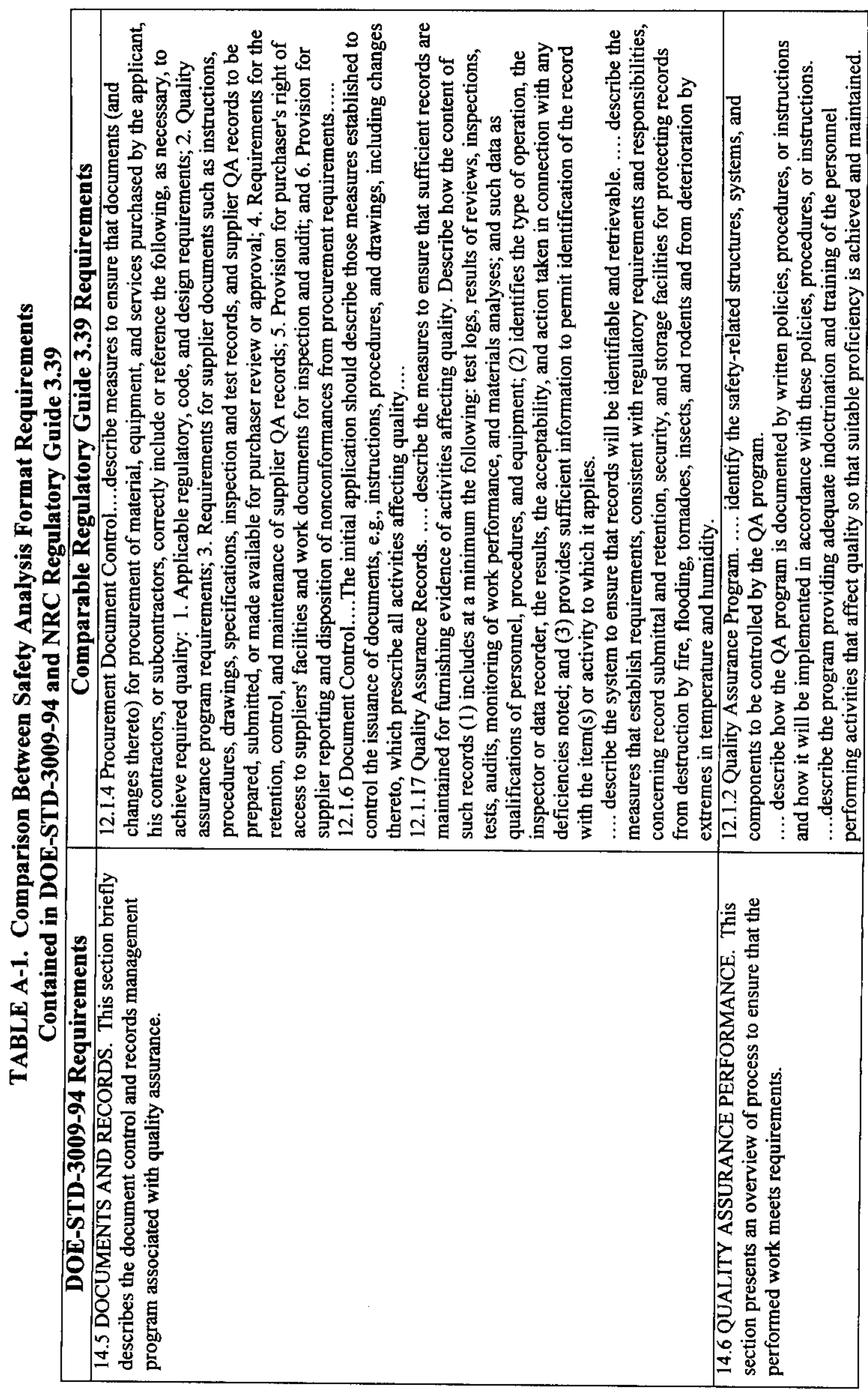


HNF-6533 Rev. 0

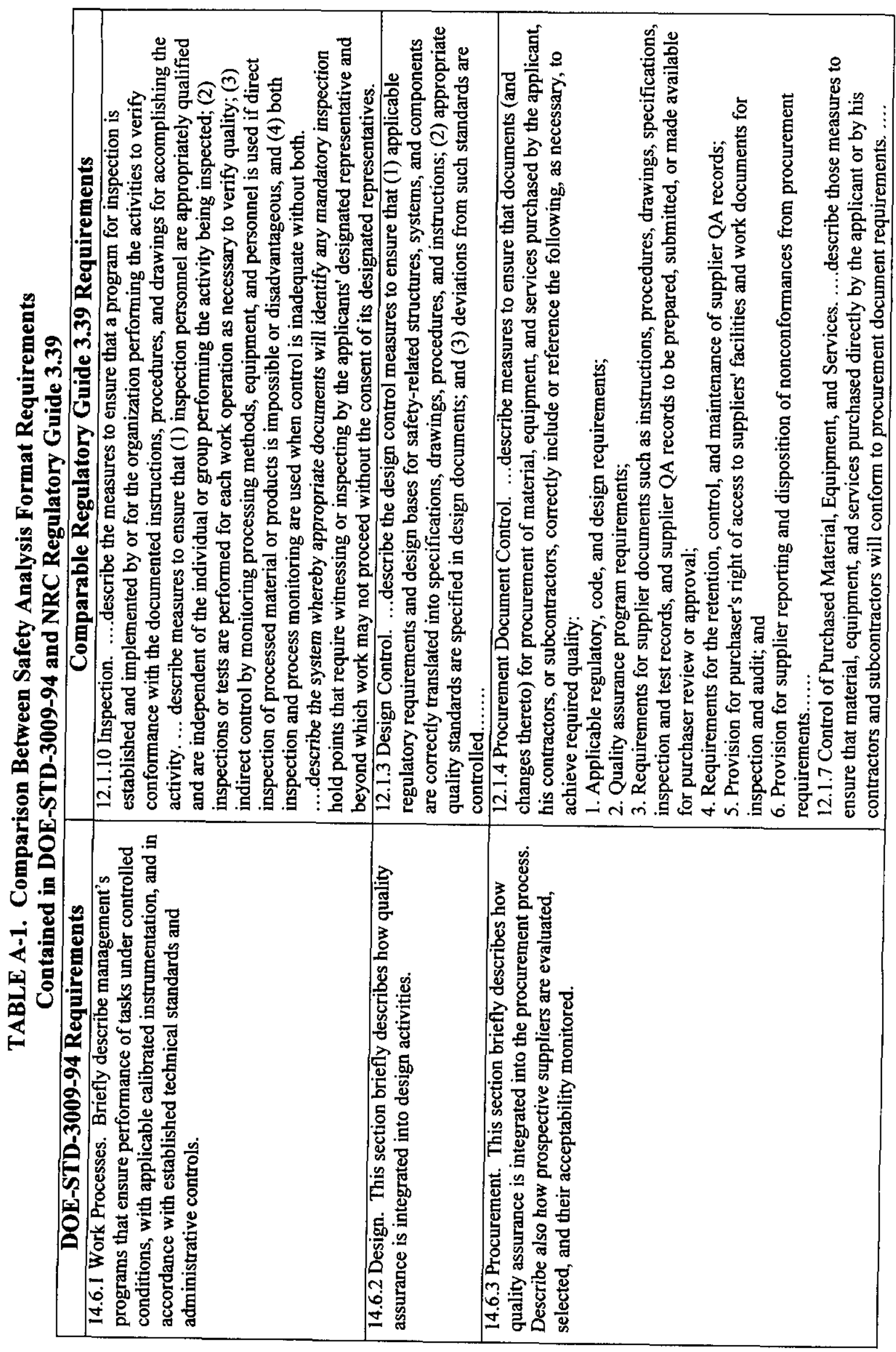


HNF-6533 Rev. 0

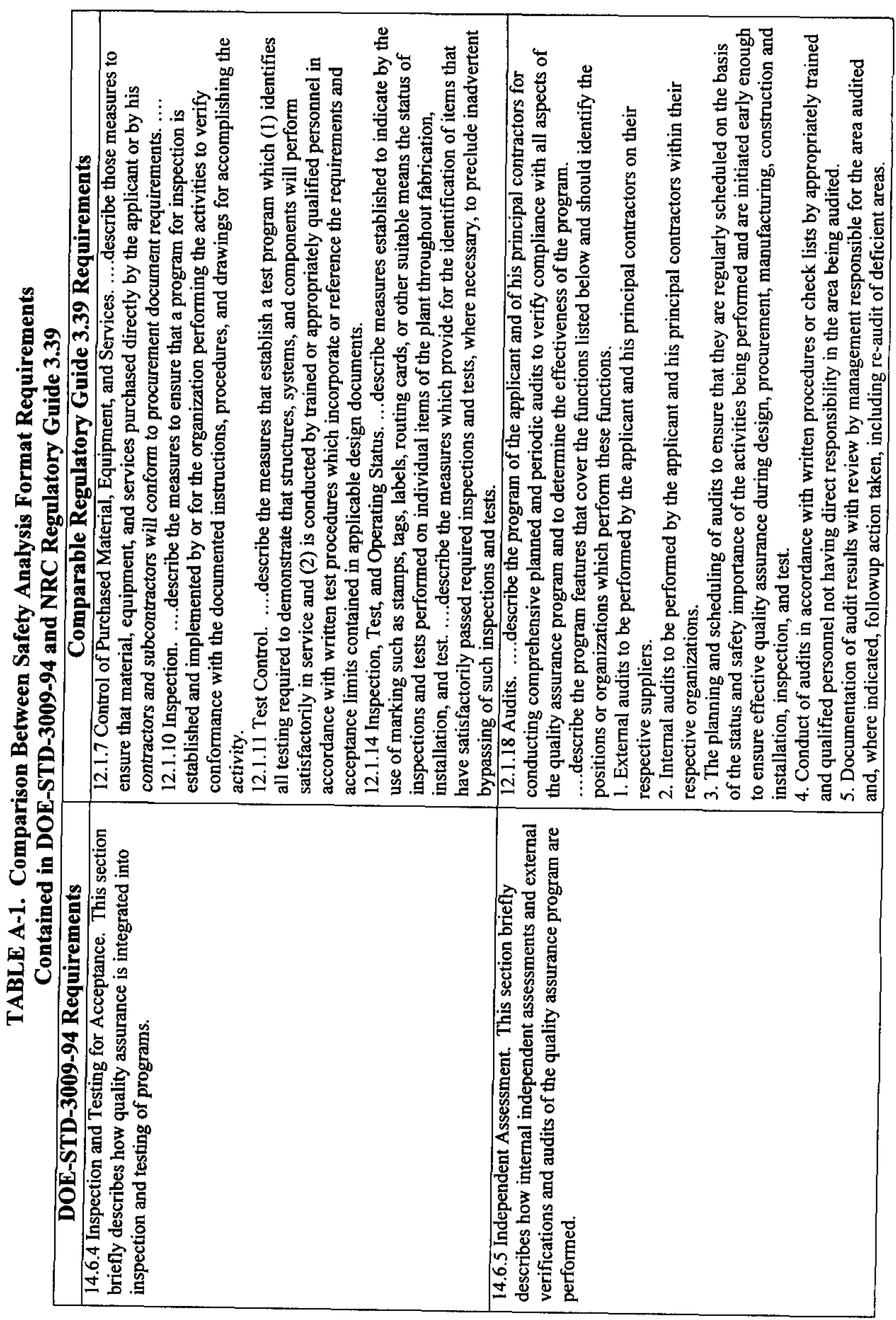


HNF-6533 Rev. 0

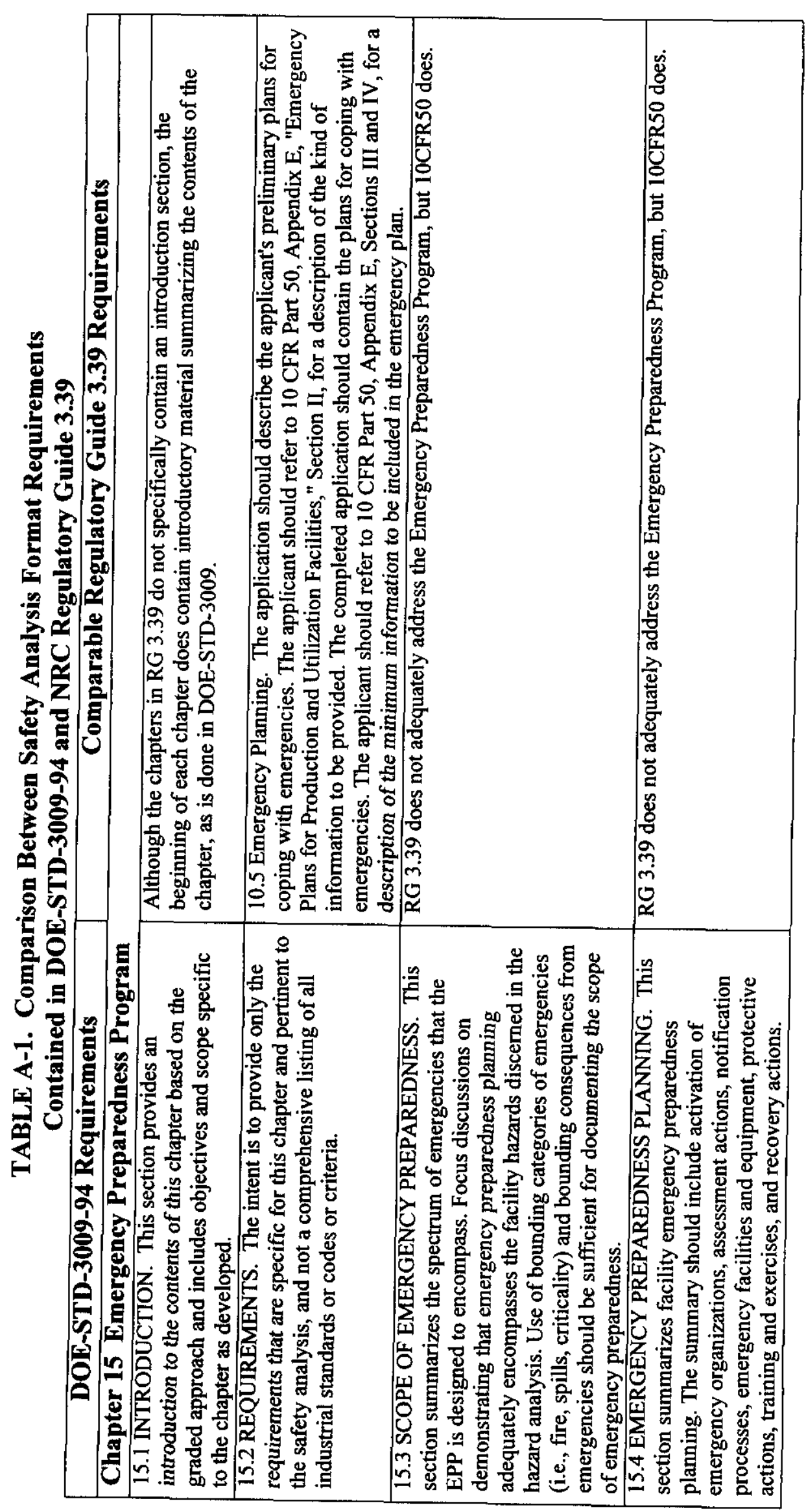


HNF-6533 Rev. 0

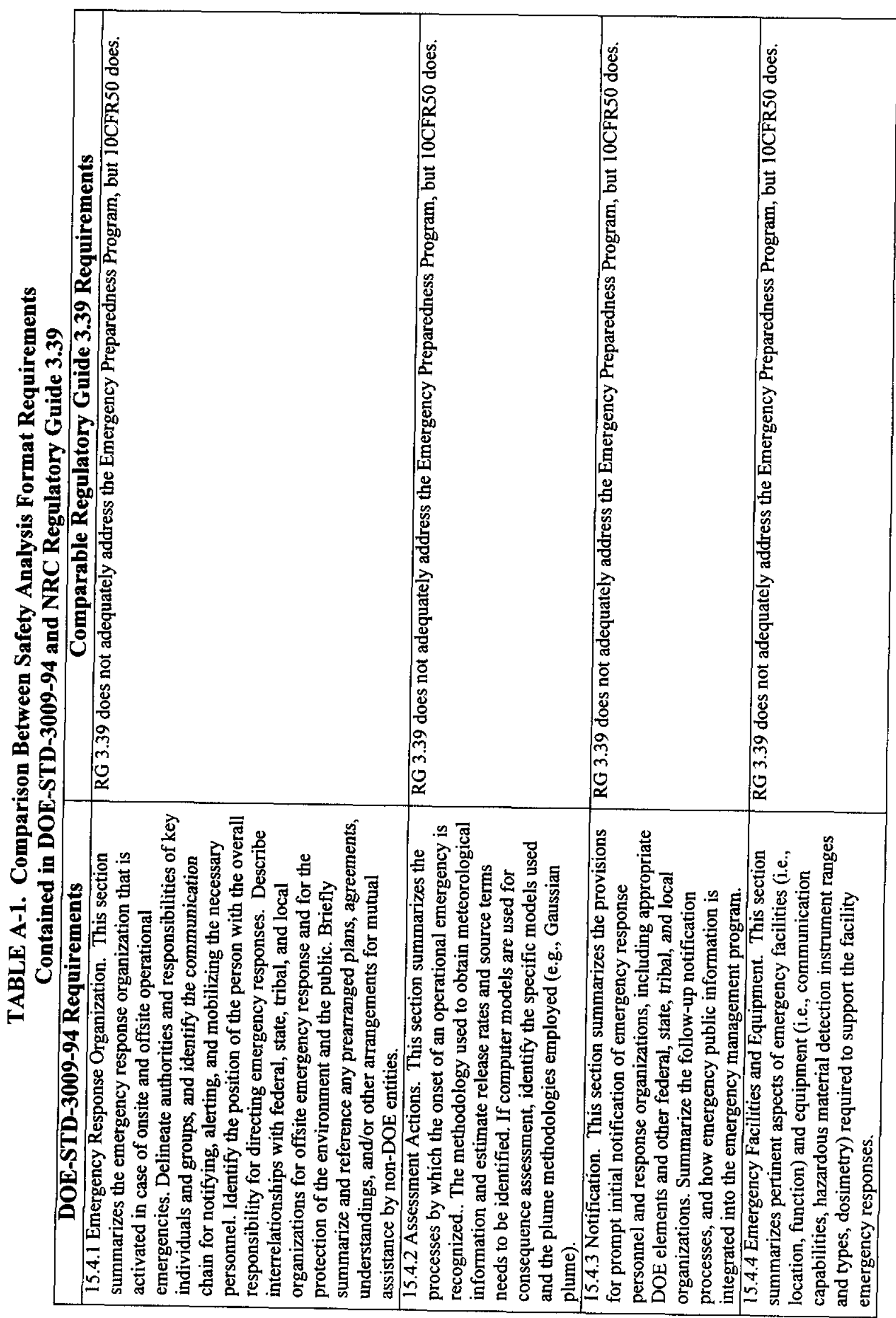


HNF-6533 Rev. 0

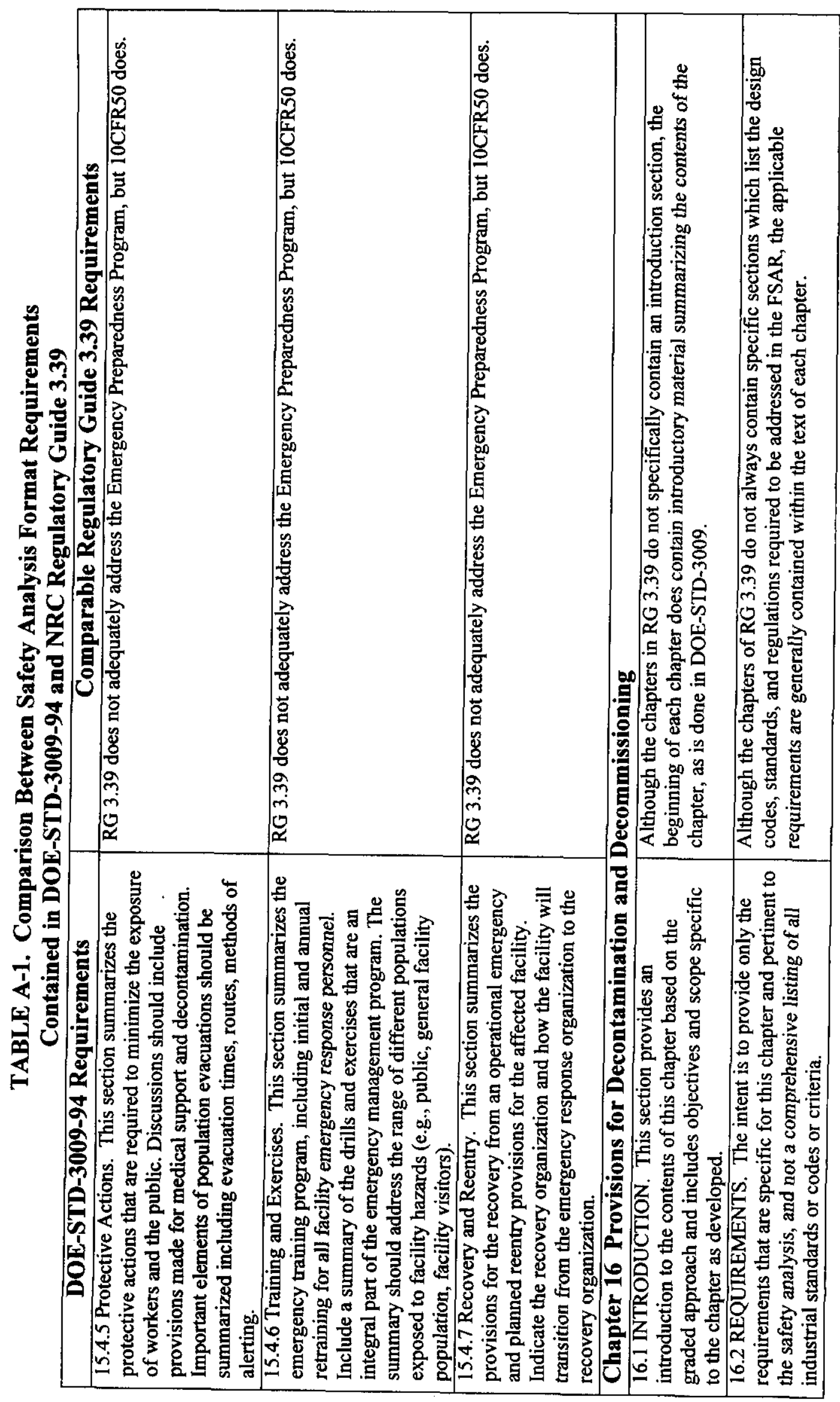


HNF-6533 Rev. 0

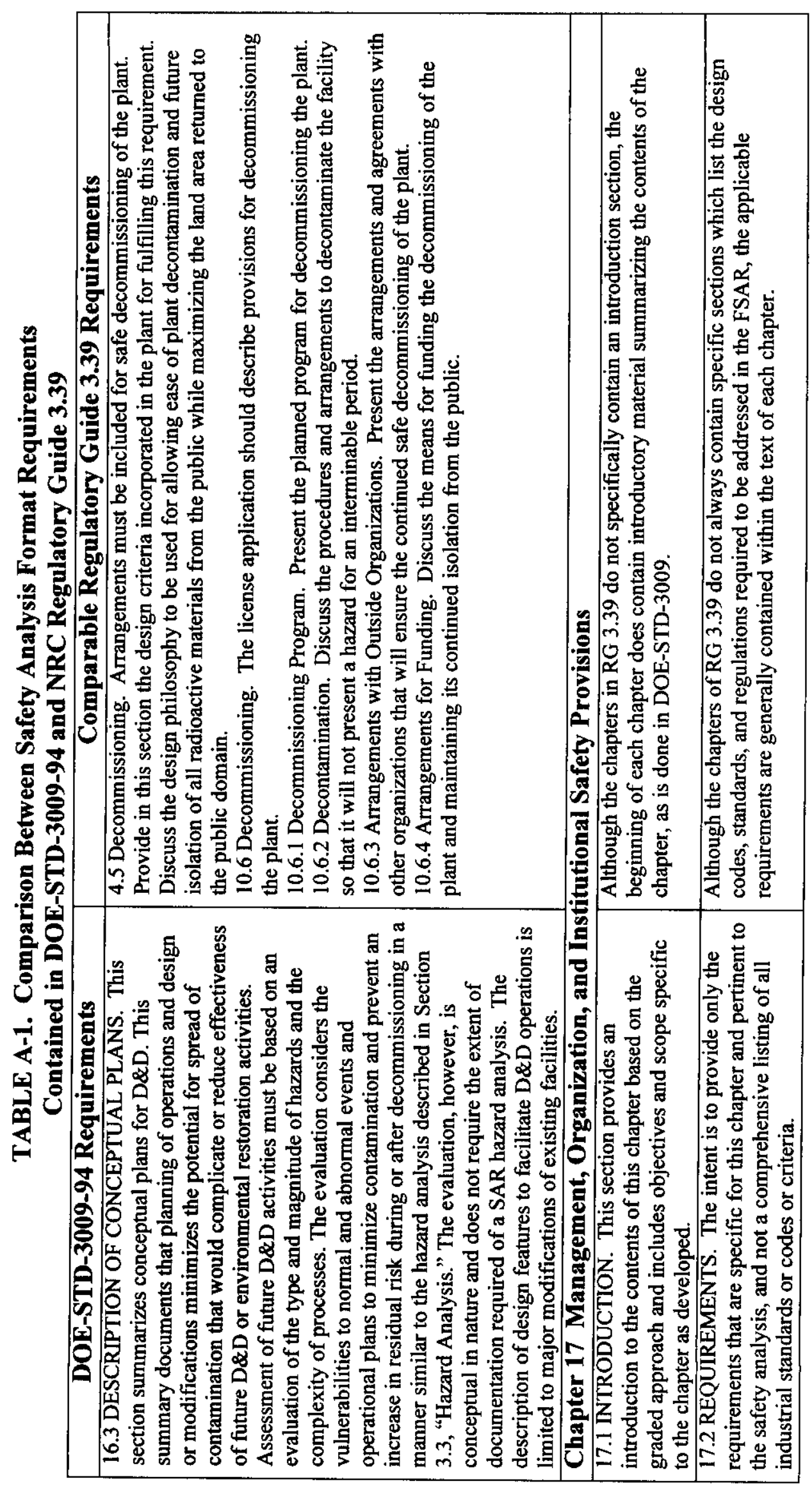


HNF-6533 Rev. 0

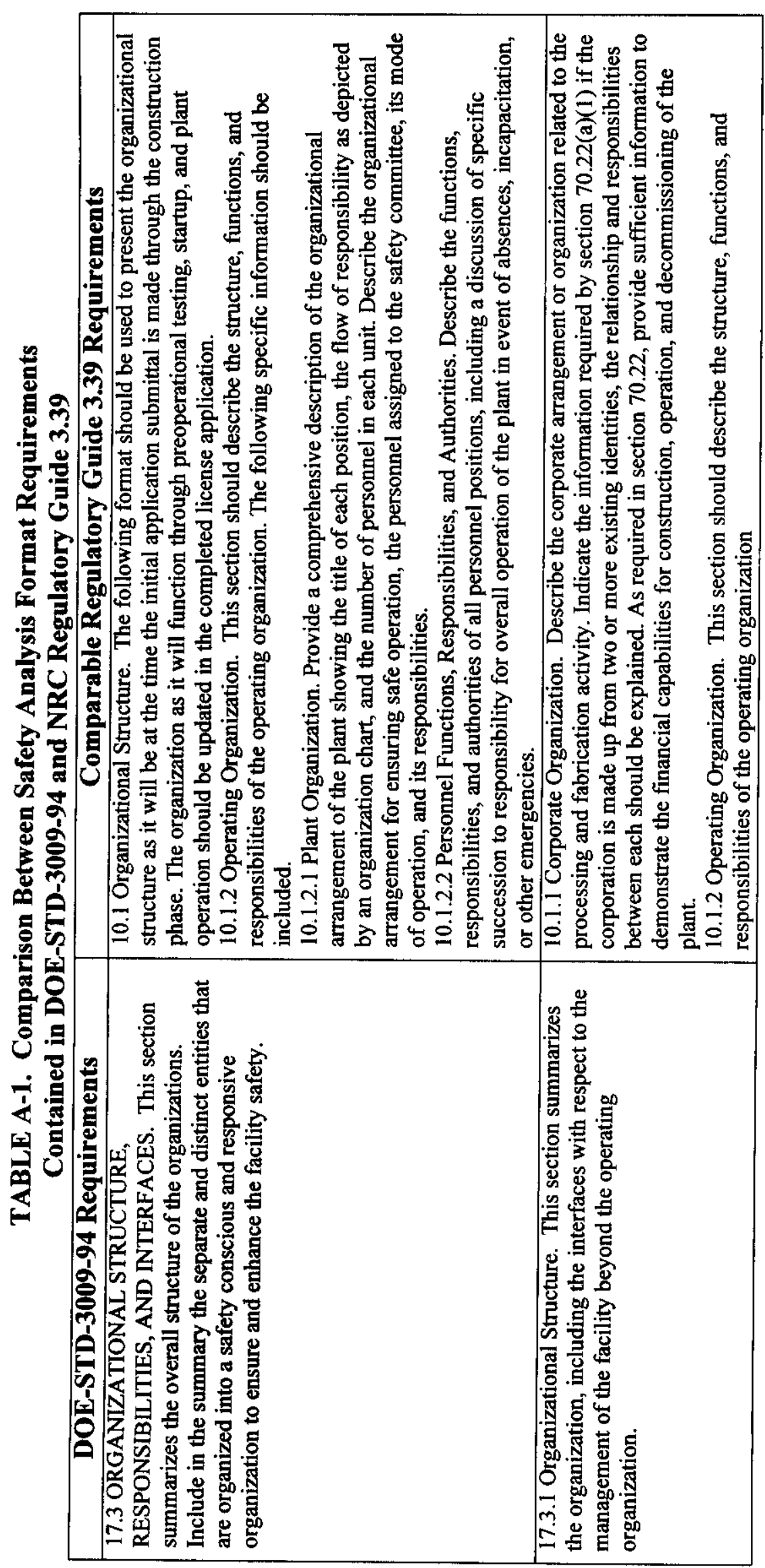


HNF-6533 Rev. 0

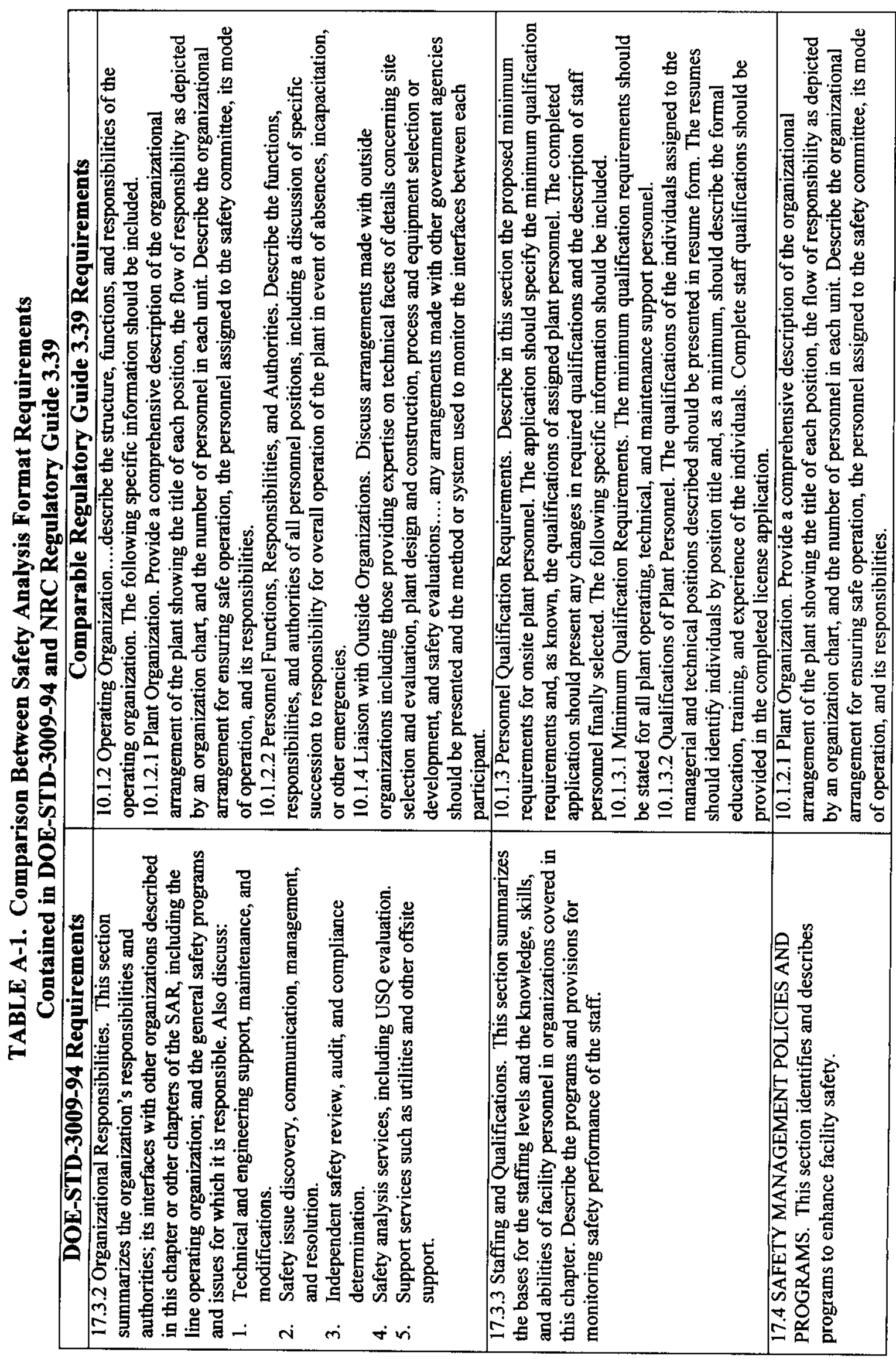


HNF-6533 Rev. 0

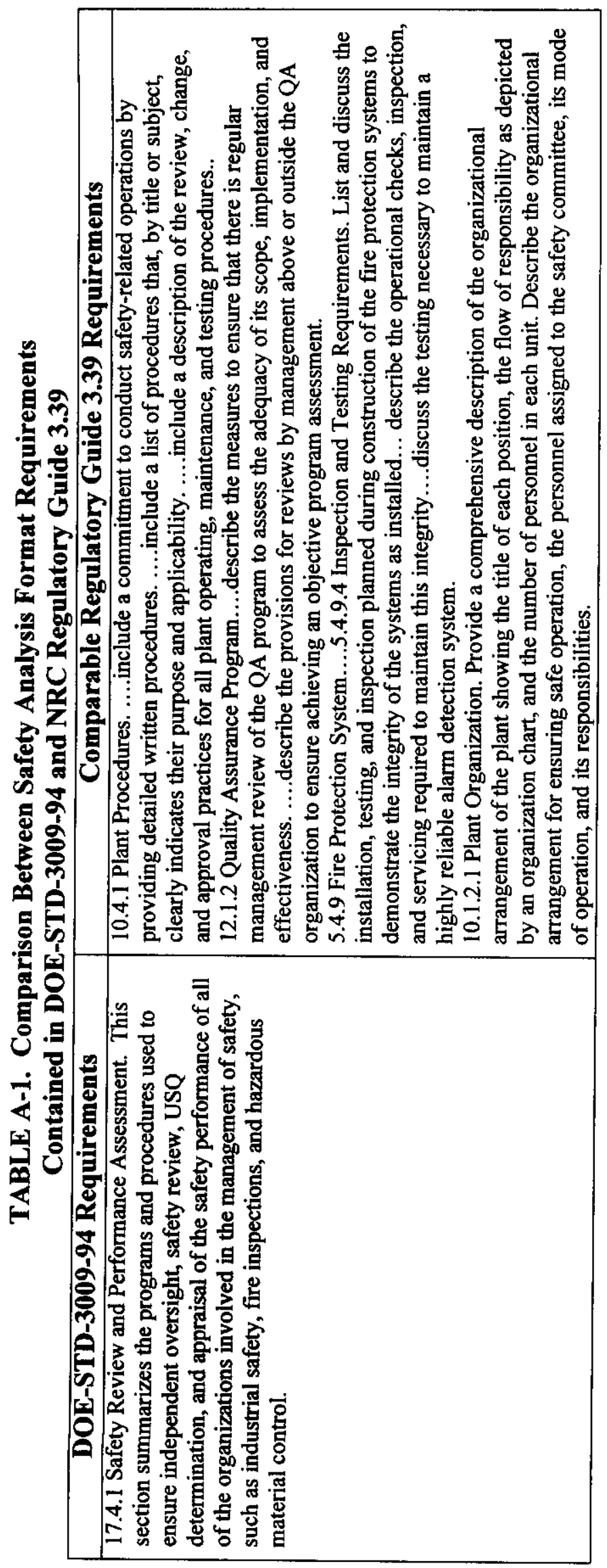


HNF-6533 Rev. 0

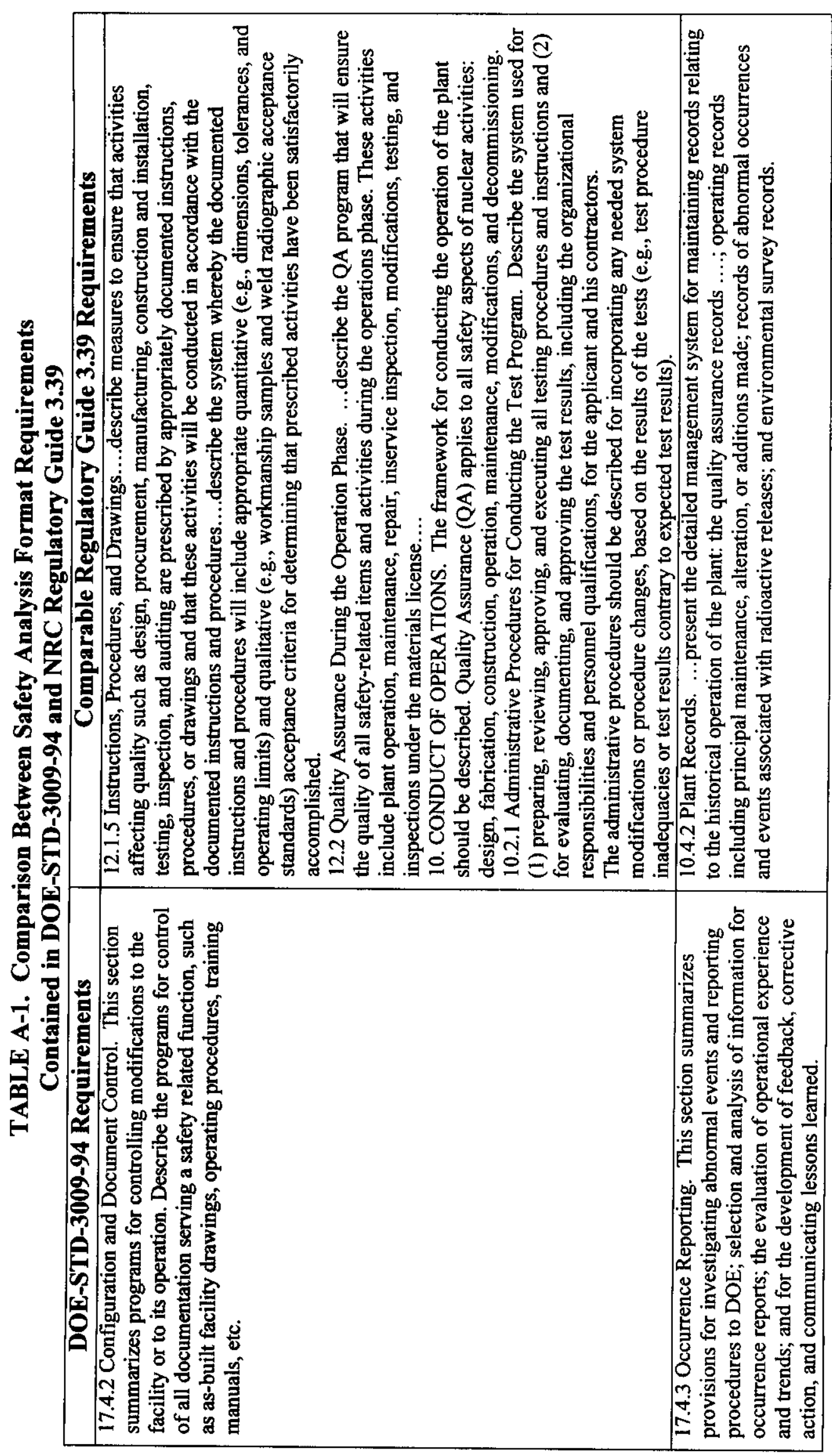


HNF-6533 Rev. 0

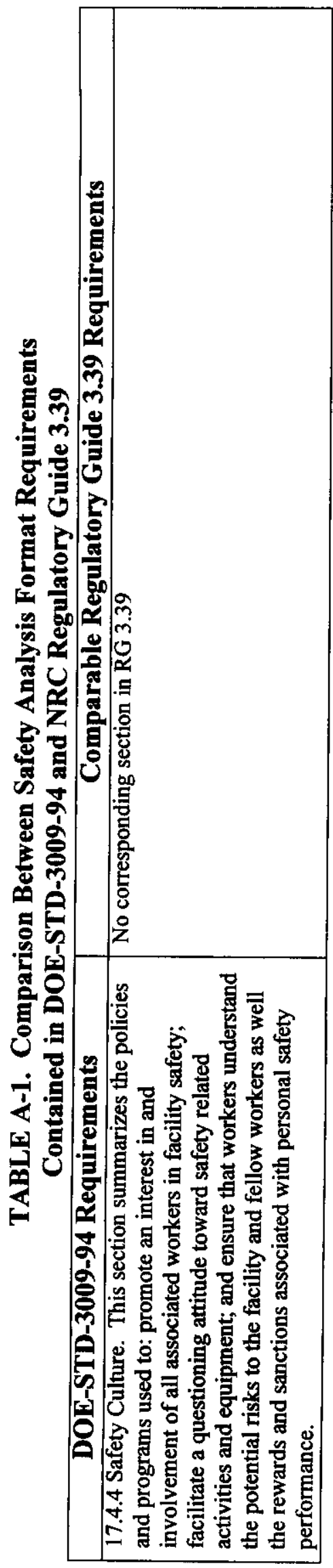


HNF-6533 Rev. 0

This page intentionally left blank. 


\section{DISTRIBUTION SHEET}

To

Distribution

Project TitleMork Onder

Comparison Evaluation of PFP FSAR and NRC Reg. Guide 3.39 with the DOE Standard DOE-STD-3009-94.

B. F. Burton

L. E. Edvalson

D. R. Groth

J. P. King

J. J. Mccracken

A. L. Ramble

J. E. Bramson

R. D. Redekopp

J. E. Shapley

J. C. Lavender

M. K. Ullah

S. E. Nunn

E. E. Oscarson

J. W. Todd

Central Files

DOE/RL Reading Room

R. A. Burk

R. W. Szempruch

M. D. Prisc

R. H. Meichle
From

M.K.Ullah

\section{Name}

$\mid$

Page 1 of 1

Date 7/24/00

EDT No. 627571

ECN No. N/A

\begin{tabular}{l|c|c|c|} 
MSIN & $\begin{array}{c}\text { Text } \\
\text { With All } \\
\text { Attach. }\end{array}$ & Text Only & $\begin{array}{c}\text { Attach.J } \\
\text { Appendix } \\
\text { Only }\end{array}$ \\
\hline
\end{tabular}

EDT/ECN Only 